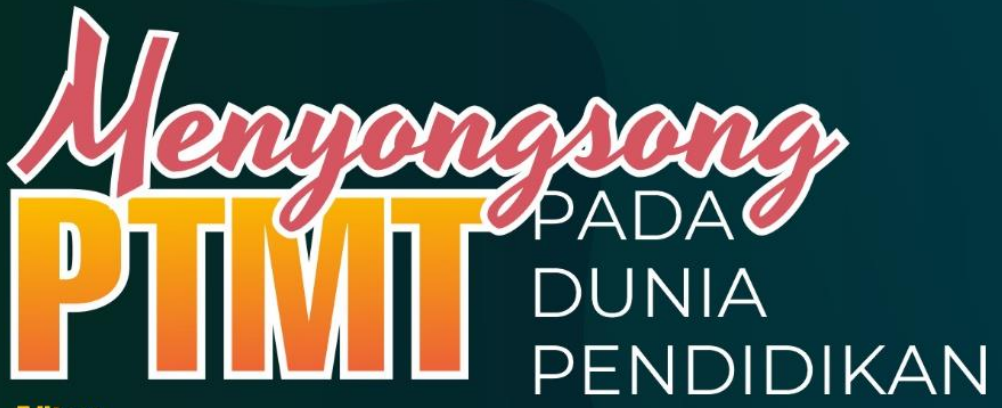

Editor:

Dr. Adi Wijayanto, S.Or., S.Kom., M.Pd., AIFO.

Dr. Rijal Firdaos, M.Pd

Dr. Ika Novitaria Marani, S.Pd, SE, M.Si

Arrinda Luthfiani Ayzzaro', S.Pd

\title{
Pengantar:
}

Prof. Dr. H. Akhyak, M.Ag.

Direktur Pascasarjana UIN SATU

(Sayyid Ali Rahmatullah Tulungagung)

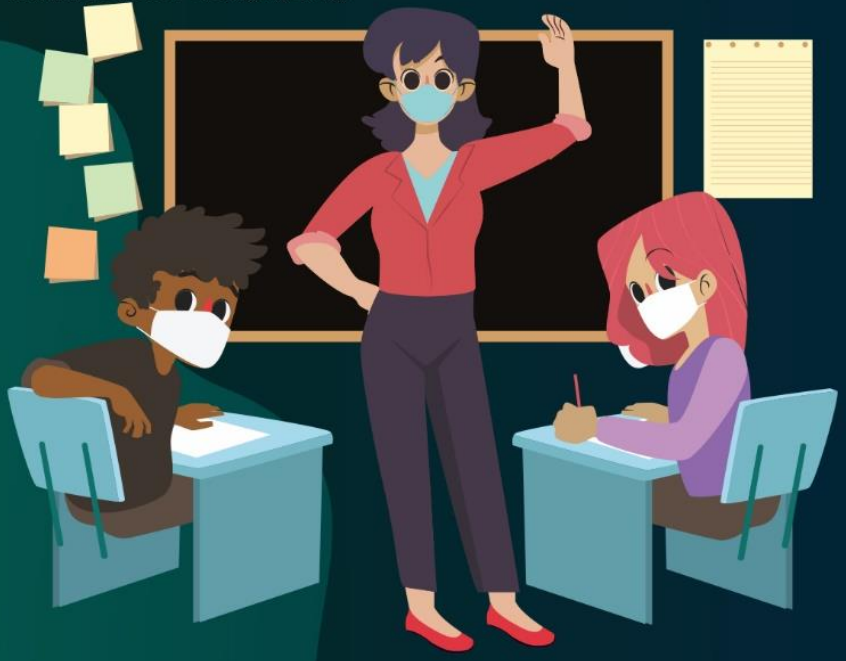

Rita Meutia | Abdul Gafur | Hetilaniar | Putri Wulan Dhari | Apridar

Gatot Sarmidi | Sri Yulia Sari | Siti Marlida | Selfi Lailiyatul Iftitah

Maria Marietta Bali Larasati | Syarifuddin I Dini Selasi

Almira Keumala Ulfah | Cory Vidiati | Shelly Midesia | Diah Lukitasari

Lathifaturahmah | Amik Nadziroh | Muhammad Yusuf

Muhammad Julijanto | Nazri Adlani | Petrus Anton Tage Saka

Femi Fauziah Alamsyah | Saepul Bahri | Hermus Hero | Silvi Aryanti

Darwin | Natalia Peni | Nur Aniyah | Linda Arisanty | Nurhidayah 


\section{MENYONGSONG PTMT PADA DUNIA PENDIDIKAN}

| Rita Meutia | Abdul Gafur | Hetilaniar |

| Putri Wulan Dhari | Apridar | Gatot Sarmidi | | Sri Yulia Sari | Siti Marlida | Selfi Lailiyatul Iftitah |

| Maria Marietta Bali Larasati | Syarifuddin | |Dini Selasi|Almira Keumala Ulfah | Cory Vidiati | |Shelly Midesia | Diah Lukitasari | Lathifaturahmah|

|Amik Nadziroh | Muhammad Yusuf |

| Muhammad Julijanto | Nazri Adlani |

|Petrus Anton Tage Saka | Femi Fauziah Alamsyah | Saepul Bahri | | Hermus Hero | Silvi Aryanti | Darwin |Natalia Peni | Nur Aniyah | | Linda Arisanty | Nurhidayah|

Editor:

Dr. Adi Wijayanto, S.Or., S.Kom., M.Pd., AIFO.

Dr. Rijal Firdaos, M.Pd

Dr. Ika Novitaria Marani, S.Pd, SE, M.Si

Arrinda Luthfiani Ayzzaro', S.Pd

Pengantar:

Prof. Dr. H. Akhyak, M.Ag.

Direktur Pascasarjana UIN SATU

(Sayyid Ali Rahmatullah Tulungagung) 


\section{MENYONGSONG PTMT PADA DUNIA PENDIDIKAN}

Copyright (C) Rita Meutia, dkk, 2021.

Hak cipta dilindungi undang-undang

All right reserved

Editor: Adi Wijayanto, dkk

Layout: Kowim Sabilillah

Desain cover: Diky M. Fauzi

ix $+235 \mathrm{hlm}: 14$ x $21 \mathrm{~cm}$

Cetakan Pertama, Desember 2021

ISBN: 978-623-6364-66-6

\section{Anggota IKAPI}

Hak cipta dilindungi undang-undang. Dilarang mengutip atau

memperbanyak sebagian atau seluruh isi buku ini tanpa izin tertulis dari penerbit.

Diterbitkan oleh:

\section{Akademia Pustaka}

Perum. BMW Madani Kavling 16, Tulungagung

Telp: 081216178398

Email: redaksi.akademia.pustaka@gmail.com

Website: akademiapustaka.com 


\section{KATA PENGANTAR}

Ihamdulillahi Rabbilalamin kehadirat Allah SWT yang
maha kuasa atas perkenan-Nya buku bunga rampai edisi September tahun 2021 yang berjudul "Menyongsong PTMT Pada Dunia Pendidikan" dapat diselesaikan dengan sebaik-baiknya atas sumbangsih ide/gagasan dan pemikiran dari para pakar pendidikan dan stake holder.

Tulisan dalam buku ini adalah buah pikiran para penulis dari berbagai profesi baik itu guru, dosen dan bahkan ada juga yang berasal dari Instansi pemerintah yang menduduki jabatan struktural dengan latar belakang pendidikan yang berjenjang dan berbeda-beda satu sama lainnya baik yang profesinya berkaitan dengan dunia pendidikan maupun lainnya, semua menjadi satu dalam tulisan yang dapat memperkaya pemikiran para pembaca buku Bunga Rampai ini.

Kerinduan yang sangat tinggi akan proses belajar secara normal menjadi pemikiran yang mendasar dari para penulis Buku Bunga Rampai ini untuk berbagi pemikiran, sehingga muncul berbagai topik yang berbeda-beda dalam tulisan ini sehingga sangat layak untuk dibaca dan dapat memperkaya pemikiran para pembaca seperti apa kondisi riil dan penerimaan para murid, orangtua dan masyarakat di tengah kondisi pandemi yang masih belum tuntas secara seutuhnya. Kondisi ini harus disikapi semua pihak dengan meningkatkan pengetahuannya, keterampilannya dan perilaku seperti apa yang harus diwujudkan di pasca pandemi ini. 
Proses belajar di dunia pendidikan pada pasca pandemi covid-19 memang akan berjalan unik dan menarik untuk dikaji secara empiris, teoretis dan berbagai pengalaman yang dialami guru dan murid selama proses belajar daring (online) dapat dijadikan inspirasi untuk diurai dalam wujud tulisan-tulisan ringan yang layak untuk di ketahui banyak orang dan layak dimuat dalam Buku Bunga Rampai ini. Para penulis buku ini akan berbeda sudut pandangnya melihat penyelenggaraan pendidikan di pasca pandemi, tetapi pada prinsipnya sama yakni bagaimana proses belajar di sekolah dan di rumah siswa dapat mengikutinya dan berbagai materi yang tertinggal selama proses belajar daring selama kurun waktu 2 tahun ini dijadikan dasar berpikir yang kuat untuk mau lebih meningkatkan lagi keinginan belajarnya baik di sekolah maupun di rumah.

Tulisan dalam buku Bunga Rampai ini sangat menarik untuk dibaca untuk memperkaya pemikiran setiap pembaca dan banyak pemikiran di luar berpikir selama ini yang dapat diperoleh dari pemikiran orang lain. Marilah jadikan pemikiran dan pengalaman empiris orang lain yang tertuang dalam Buku Bunga Rampai ini untuk memperkaya pemikiran dan pengalaman pribadi, siapapun dan apapun profesinya, dalam rangka menyongsong Indonesia emas 2045.

Meskipun penyelenggaraan pendidikan pasca pandemi belum optimal dilaksanakan di sekolah, tetapi berbagai pemikiran dalam Buku Bunga Rampai sudah ada dan ini menunjukkan bahwa pemikiran para penulis lebih maju dalam mensikapi suatu kondisi di masa akan datang. Selamat menikmati buku ini dengan membacanya secara 
seksama, buat para pembaca baik dari kalangan akademisi, mahasiswa, pelajar, masyarakat umum. Sekian

Tulungagung, 12 Desember 2021

Prof. Dr. H. Akhyak, M.Ag.

Direktur Pascasarjana UIN SATU 


\section{DAFTAR ISI}

KATA PENGANTAR

Oleh Prof. Dr. H. Akhyak, M.Ag. ................................................. iii

DAFTAR ISI ........................................................................vi

\section{BAB I}

KEBERLANJUTAN KEGIATAN PASCAPANDEMI .................... 1

KEBERLANJUTAN PENDIDIKAN

DI MASA PANDEMI COVID-19

Oleh Rita Meutia

PEMBELAJARAN AGAMA ISLAM PASCAPANDEMIC

DI UNIT PELAKSANA TEKNIS MATAKULIAH

PENGEMBANGAN KEPRIBADIAN

UNIVERSITAS SRIWIJAYA

Oleh Abdul Gafur

EKSPLORASI MATA KULIAH PRAKTIK PASCA PANDEMI

Oleh Hetilaniar.

OPTIMALISASI PEMBANGUNAN KOMPETENSI LITERASI

DALAM PEMBELAJARAN BAHASA INDONESIA

Oleh Putri Wulan Dhari

KESIAPAN KEBERLANGSUNGAN

PENDIDIKAN PASCA PANDEMI

Oleh Apridar

KUMPULAN PUISI BERHENTI DI KESUNYIAN SEBAGAI MEDIA PEMBELAJARAN APRESIASI SASTRA

PASCA PANDEMI COVID 19

Oleh Gatot Sarmidi.

MODEL PEMBELAJARAN KOLABORATIF

PASCA PANDEMI

Oleh Sri Yulia Sari. 
STRATEGI DAKWAH DI MAJLIS

TAKLIM PASCA PANDEMI

Oleh Siti Marlida

MENUMBUHKAN KEMANDIRIAN ANAK USIA DINI

MELALUI METODE MONTESSORI PADA

MASA PANDEMI COVID-19

Oleh Selfi Lailiyatul Iftitah.

UPAYA MENCINTAI KULINER FLORES MELALUI

MATA KULIAH PENDIDIKAN BUDAYA LOKAL

Oleh Maria Marietta Bali Larasati

\section{BAB II}

\section{ILMU EKONOMI PASCAPANDEMI}

STRATEGI PEMULIHAN PARIWISATA PASCA PANDEMI

Oleh Syarifuddin

PERKEMBANGAN PASAR MODAL SYARIAH INDONESIA MELALUI PASAR MENABUNG SAHAM

Oleh Dini Selasi

MEMAHAMI DASAR DASAR AKUNTANSI UNTUK PEMULA Oleh Almira Keumala Ulfah.

ONLINE SHOP:

POLA BISNIS AMAN PASCAPANDEMI

(STUDI ELLIN HIJAB DESA PRAJAWINANGUN WETAN KABUPATEN CIREBON)

Oleh Cory Vidiati

UPAYA MENGATASI MISKONSEPSI BELAJAR AKUNTANSI PADA MASA PEMBELAJARAN TATAP MUKA TERBATAS

Oleh Shelly Midesia

PENTINGNYA PEMBELAJARAN BERWIRAUSAHA

PASCA PANDEMI

Oleh Diah Lukitasari

PEMBIASAAN KEBIJAKAN PEMKAB BANDUNG BAGI UKM COFFE SHOP MASA PANDEMI HINGGA KINI

Oleh Lathifaturahmah. 
MANAJEMEN PENGEMBANGAN PARIWISATA DAN EKONOMI KREATIF WARUNG KOPI DI MASA PANDEMI

Oleh Amik Nadziroh

\section{BAB III}

PENERAPAN DAN PERMASALAHAN SELAMA PTMT

KEKURANGAN DAN KELEBIHAN PEMBELAJARAN

BLENDED LEARNING PASCA PANDEMI

Oleh Muhammad Yusuf

JOGO TONGGO:

ETOS KEDERMAWANAN DI MASA PANDEMI

Oleh Muhammad Julijanto

PERSIAPAN PRAKTIK MICROTEACHING MAHASISWA PGMI PASCA PANDEMI

Oleh Nazri Adlani

EFEKTIVITAS PEMBELAJARAN DARING DI MASA

PANDEMI CORONA VIRUS DISEASE (COVID 19)

Oleh Petrus Anton Tage Saka.

URGENSI LITERASI DIGITAL PASCA PANDEMI COVID-19

Oleh Femi Fauziah Alamsyah

DEGRADASI BUDI PEKERTI PASCA PANDEMI

Oleh Saepul Bahri

IMPLEMENTASI MODEL PEMBELAJARAN EXPERIENTIAL LEARNING PADA MATA KULIAH PENDIDIKAN KARAKTER DI TENGAH PANDEMI COVID-19

Oleh Hermus Hero

PENTINGNYA MENCUCI TANGAN SEBAGAI

TINDAKAN PENCEGAHAN COVID-19

Oleh Silvi Aryanti

PANDEMI DAN GERAKAN MAN 1 PIDIE PEDULI BERBAGI

Oleh Darwin.

LITERASI SEBAGAI TRANSPORMASI

PENINGKATKAN MINAT BACA

Oleh Natalia Peni. 
MEWUJUDKAN PROFIL PELAJAR PANCASILA PADA PEMBELAJARAN TATAP MUKA TERBATAS

PASCAPANDEMI MELALUI KEGIATAN PEMBIASAAN

Oleh Nur Aniyah

.213

EFEKTIVITAS VAKSINASI SISWA DALAM MENGHADAPI PTMPT PASCAPANDEMI COVID 19

Oleh Linda Arisanty .221

PROBLEMATIKA KARAKTER SISWA PASCA PANDEMI DALAM PEMBELAJARAN TATAP MUKA TERBATAS Oleh Nurhidayah 229 



\section{BAB I}

KEBERLANJUTAN

KEGIATAN PASCAPANDEMI

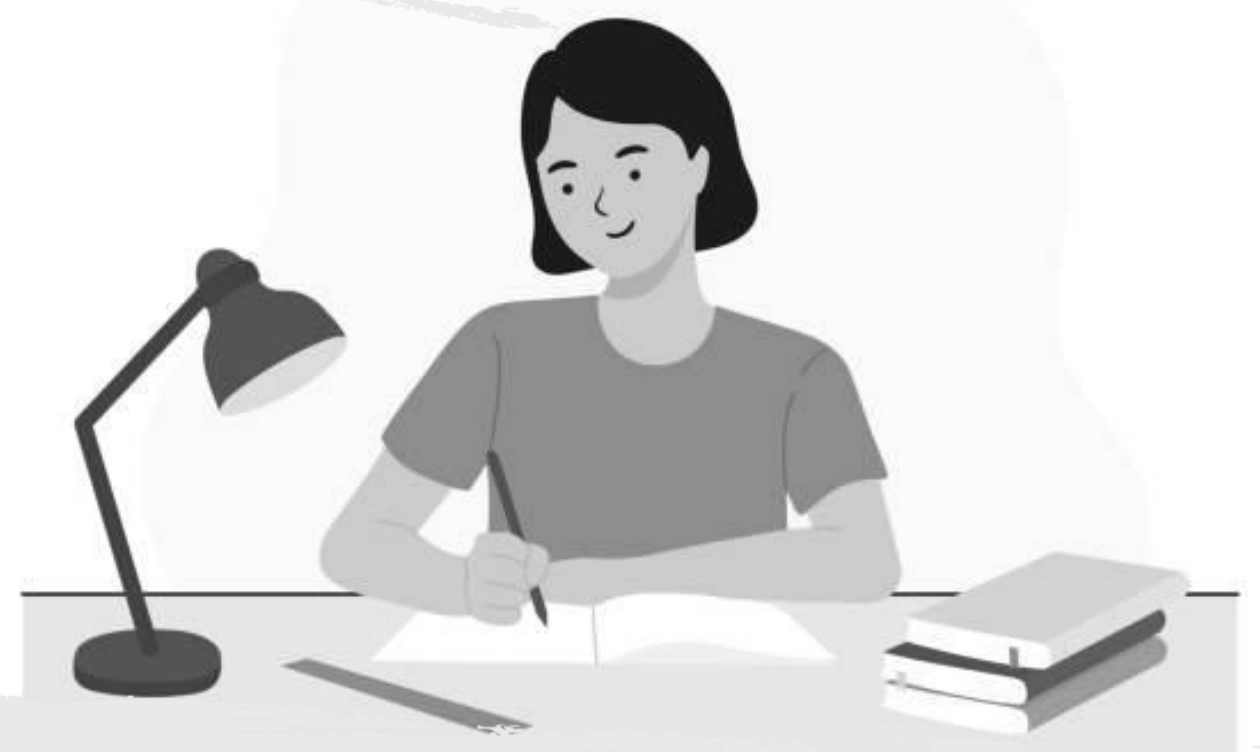


Menyongsong PTMT Pada Dunia Pendidikan 


\title{
KEBERLANJUTAN PENDIDIKAN DI MASA PANDEMI COVID-I9
}

\author{
Dr. Rita Meutia, S.E., M. Si, Ak ${ }^{1}$ \\ Universitas Syiah Kuala (USK) Aceh
}

"Kebebasan yang diterapkan kampus saat pendemi covid-19 dapat meningkatkan produktivitas untuk kemajuan dan kesejahteraan agama, bangsa dan negara dengan cara mereduksi berbagai ilmu pengetahuan yang menjurus pada kerusakan dan menghancurkan tatanan kehidupan bangsa"

\section{Pendahuluan}

W Tabah penyakit pandemi Corona Virus-19 (Covid-19) yang telah menyerang masyarakat dunia di berbagai negara. Virus super mikro, namun sangat ditakutkan tersebut ber-ditransmisikan melalui droplet (percikan air liur) yang dihasilkan saat orang yang terinfeksi batuk, bersin, atau mengembuskan nafas (WHO:2020). Droplet ini terlalu berat dan tidak bisa bertahan di udara, sehingga dengan cepat jatuh dan menempel pada lantai atau permukaan lainnya. Orang akan tertular saat menghirup udara yang mengandung Covid-19 dari orang yang telah

1Penulis lahir di Banda Aceh, 4 September 1971,Fakultas Ekonomi dan Bisnis Universitas Syiah Kuala (FEB-USK) Aceh. Sarjana Ekonomi Akuntansi FEB (1994). Magister Ilmu Ekonomi Akuntansi Universitas Padjadjaran Bandung (1999). Program Doktor Ilmu Akuntansi Universitas Sumatera Utara (2019). Gelar Profesi Akuntan diperoleh dari Ikatan Akuntansi Indonesia (1994). Buku yang telah ditulis bersama :Model Ekonomi Syariah; Fondasi Sistem Ekonomi (2020). 
dahulu tertular penyakit tersebut. Untuk mengurangi resiko tertular, maka sangat dianjurkan untuk menerapkan protokol kesehatan secara ketat.

Dengan terjadinya pandemi COVID-19 membuat prilaku masyarakat berubah di berbagai aspek dalam aktivitas keseharian. Tingkat kecemasan dan rasa ketakutan dikarenakan ketidak amanan yang dialami sebagian besar manusia seharusnya bisa disikapi dengan rasional agar dapat bertahan hidup dan juga mampu untuk membantu orang lain agar tidak cemas. Penerapan pola hidup sehat sesuai protokol kesehatan dan disiplin untuk mengikuti anjuran pemerintah harus dilaksanakan sebagai upaya mencegah penyebaran COVID-19 lebih meluas.

Di sisi lain agar roda ekonomi masyarakat tetap berputar untuk memenuhi kebutuhan keseharian, untuk dapat terpenuhinya kebutuhan hidup serta berjalannya aktivitas masyarakat dibidang ekonomi diperlukan kebijakan dan konsistensi aturan yang ditetapkan sehingga tidak merugakan para pegusahan khususnya. Dengan berjalannya perekonomian diharapkan dapat meningkatkan pendapatan untuk membiayai kebutuhan akan barang dan jasa sehari-hari. Untuk itu diperlukan berbagai alternative untuk memenuhi kebutuhan tersebut. Salah satu kegiatan yang ramai dijalankan di masa pandemi ini adalah transaksi online yang sering disebut digitalisasi ekonomi dan keuangan. Adalah suatu keharusan menyiapkan infrastruktur digitalisasi serta kesiapan sumberdaya manusia dalam menjalankan perangkat teknologi tersebut.

Di era globalisasi yang sangat kompetitif ini sangat diperlukan lulusan dituntut mampu menguasai berbagai keahlian serta ilmu pengetahuan yang dapat diaplikasikan dalam dunia kerja nantinya. Perkembangan teknologi dan 
ilmu pengetahuan yang begitu cepat, menuntut semua pihak agar mampu beradaptasi serta memiliki keahlian tertentu sesuai dengan perkembangan zaman. Dunia kerja sekarang ini diberpacu untuk dapat meningkatkan produktivitas yang optimal agar ia mampu bersaing serta dapat meningkatkan produktivitas. Untuk itu keberadaan sumber daya manusia berkualitas dalam mengisi peluang kerja merupakan suatu keharusan yang mesti dipersyaratkan sehingga mampu berproduksi optimal dengan efektif dan efisien.

Kampus sekarang ini dituntut untuk dapat menyiapkan sumberdaya manusia yang mumpuni untuk menyuplay kebutuhan tenaga kerja. Sinegisitas yang baik sangat diperlukan dalam menyiapkan generasi yang melek teknologi informasi khususnya. Perkembangan ilmu pengetahuan dan teknologi yang begitu cepat, mengharuskan perguruan tinggi untuk menyiapkan lulusan yang mampu menjawab tantangan tersebut agar tidak ditinggalkan oleh perkembangan zaman yang kompetitif tersebut.

Kebijakan terhadap penerapan pembatasan sosial berskala besar (PSPB) serta berbagai kebijakan untuk memutuskan mata rantai wabah pandemi covid-19 yang berimbas kepada pertumbuhan ekonomi yang stagnant, perlu dilakukan pembukaan kembali terhadap sektor-sektor yang relative aman agar pertumbuhan ekonomi mampu bangkit kembali seperti industry farmasi, logam, perkebunan dan kehutanan. Sinergisitas dalam menyikapi setiap kebijakan sangat penting dilakukan agar kita dapat melewati wabah ini dengan baik dan benar. 


\section{Pentingnya Kolaborasi Dunia Usaha}

Kemajuan teknologi informasi yang begitu pesat, menjadikan dunia ini tidak lagi terbatasi oleh jarak dan waktu. Untuk meningkatkan produktivitas yang optimal, dunia usaha dituntut untuk mampu berkompetisi terutama dengan berbagai produk sejenis yang masuk dari berbagai belahan dunia. Suatu langkah tepat apabila dunia usaha dapat berkolaborasi atau bekerjasama dalam melakukan produksinya sehingga memperoleh produk yang lebih murah serta efisien. Kolaborasi merupakan salah satu bentuk bekerja sama untuk mencapai tujuan bersama (Abulsyani:1994). Kolaborasi tentu akan melibatkan berbagai pihak untuk pembagian tugas, dimana setiap orang mengerjakan pekerjaan yang merupakan tanggung jawabnya demi tercapainya tujuan bersama. Dengan kolaborasi tentu perusahaan diharapkan akan lebih terfokus pada bidang utama yang dilaksanakan, hal ini tentu akan terbentuk spesialisasi sesuai keahlian yang dimiliki. Di era globalisasi seperti sekarang ini, untuk dapat meningkatkan produktivitas, maka kolaborasi menjadi suatu keharusan untuk dapat menghadapi persaingan yang semakin ketat.

Lembaga pendidikan tinggi yang menyiapkan sumber daya manusia sangat penting untuk menyelaraskan diri dengan tuntutan dunia kerja. Dimana dengan semakin terbukanya berbagai peraturan dan ketentuan-ketentuan di kampus, menjadi tuntutan untuk melakukan kerjasama dengan berbagai perusahaan besar khususnya agar program- program yang ditawarkan semakin tepat sasaran. Kerjasama dengan dunia usaha tidak hanya sebatas kerja praktek dan pengisian tenaga kerja yang dibutuhkan, namun harus mampu menciptakan peta jalan atau roadmap 
untuk melaksanakan program jangka Panjang bagi kedua belah pihak. Perusahaan tidak harus membuat laboratorium sendiri serta merekrut para peneliti dengan biaya yang tinggi untuk keperluan berbagai research, yang memang harus mereka lakukan agar mampu menghasilkan produk baru yang kompetitif dan disenangi konsumen.

Banyak pakar atau tenaga ahli dengan berbagai disiplin ilmu serta lulusan dari universitas-universitas terkemuka dari berbagai penjuru dunia yang dimiliki kampus perlu diberdayakan lebih optimal. Pemberdayaan dosen utamanya dengan cara pemberian ruang dalam mengaplikasikan keahlian sejalan tuntutan tri dharma perguruan tinggi yaitu melakukan pendidikan, penelitian dan pengabdian kepada masyarakat untuk pengembangan ilmu pengetahuan kedepan sangatlah penting untuk dilakukan. Sehingga keberadaan laboratorium yang kredible merupakan kebutuhan utama setiap kampus.

Dengan adanya inisiasi dari perusahaan besar untuk berkolaborasi membangun laboratoriumnya di kampus, tentu akan membuat perusahaanya menjadi lebih efisien dan efektif dibandingkan bila membangun sendiri di dalam perusahaanya. Mengelola sendiri laboratorium oleh perusahaan tentu lebih besar biayanya dibandingkan bekerja sama dengan kampus. Luaran dari research yang dilakukan secara kolaborasi tersebut dapat dimanfaatkan oleh kedua pihak, dimana kampus dapat mengembangkan ilmu pengetahuan dan teknologi, sedangkan perusahaan memperoleh hasil yang akan diproduksikan serta dipasarkan kepada konsumen.

Agar dapat merealisasikan kolaborasi penting yang sangat bermanfaat ini, diperlukan kebijakan pemerintah secara serius melalui kementerian terkait seperti, 
Kementrian Pendidikan, Kebudayaan, Riset dan Teknologi, Kementrian BUMN, Kementrian Tenaga Kerja dan Kementrian Perindustrian membuat keputusan bersama untuk mewajibkan perusahan besar khususnya, agar dapat membangun laboratoriumnya di kampus terdekat dari areal kerja mereka. Dengan terlaksananya program mulia tersebut, tentu akan sangat bermanfaat bagi kampus dan perusahaan, dimana hasil dari riset tersebut dapat diaplikasikan langsung oleh perusahaan dan kampus guna memperoleh nilai tambahnya. Salah satu contoh bentuk kerja sama tersebut sebagaimana yang telah dilaksanakan oleh Perusahaan elektronik Samsung dengan berbagai universitas di Korea.(ui.ac.id)

\section{Penguatan Pendidikan Karakter}

Kampus yang mengelola pendidikan tinggi dibangun dengan memberi kesempatan yang luas untuk meningkatkan ilmu pengetahuan dan teknologi bagi lulusannya. Pada umumnya perusahaan yang akan merekrut tenaga kerjanya, mereka selalu menilai karakter dan track record dari calon tenaga kerja seperti tingkat religious, kejujuran dan sikap, serta komitmen merupakan pertimbangan utama. Sehingga pendidikan karakter merupakan materi yang sangat penting yang dapat memagari peserta didik untuk tidak bertindak kasar serta merugikan orang lain..

Salah satu sikap dan prilaku yang baik sebagai mana yang diperlihatkan oleh kinerja dan komitmen masyarakat Jepang yang menghantarkan negaranya kepada produktivitas yang tinggi serta berada pada golongan negara maju merupakan contoh nyata bahwa pendidikan karakter sangat diperlukan dalam pendidikan. Untuk Masyarakat Indonesia yang telah ditempa prilaku dan 
karakternya melalui pendidikan agama yang baik dan benar perlu dipertahankan dan ditingkatkan. Dengan tingginya nilai-nilai religious diharapkan etika moral yang bijak dan santun dapat diaplikasikan sejalan dengan adat serta kebiasaan orang timur.

Kebebasan yang diprogramkan oleh kampus diharapkan menjadi kenyamanan dalam melaksanakan proses pendidikan yang berwawasan dan ber-etika. Sehingga kampus bisa melahirkan berbagai karya inovasi yang dapat memberikan sumbangan terhadap peningkatan dan pengembangan ilmu pengetahuan kedepan. Pengembangan ilmu pengetahuan yang dilahirkan kampus hendaknya dapat memberi pencerahan kepada masyarakat untuk kebaikan bersama.

Saatnya Perguruan Tinggi untuk mereduksi berbagai ilmu pengetahuan yang menjurus pada kerusakan dan menghancurkan tatanan kehidupan bangsa dan negara. Dimana kebebasan yang diberikan tentu tidak untuk melanggar kebebasan orang lain yang ingin hidup rukun dan damai. Moga kebebasan yang diterapkan kampus saat pendemi covid-19 dapat meningkatkan produktivitas untuk kemajuan dan kesejahteraan agama, bangsa dan negara.

\section{Daftar Pustaka}

Abdulsyani, 1994. Sosiologi Sistematika Teori dan Terapan. Jakarta : Bumi Aksara

Afrizal, 2014. Metode Penelitian kualitatif (Sebuah Upaya Mendukung Penggunaan Penelitian Kualitatif dalam Berbagai Disiplin Ilmu). Jakarta: PT. Raja Grafindo Persada.

Azanella L. A. (2020). 9ompas9 PSBB Hingga Upaya Pencegahan Covid-19. 
https://www.kompas.com/tren/read/2020/04/13/1534 15265/apa-itu-psbbhingga-jadi-upaya-pencegahanCovid-19. Diakses pada 15 November 2021.

Budianto, Y. (2020). Memahami Karakter Virus dan Penyakit Covid-19.

https://bebas.kompas.id/baca/riset/2020/03/14/mema hami-karakter-virusdan-penyakit-korona-Covid-19/. Diakses tanggal 15 Novemeber 2021

Diana. Hakim, Lukman (2020) Strategi Kolaborasi Antara Perguruan Tinggi „Industri dan Pemerintah: Tinjuaan Konseptual Dalam Upatya Meningkatkan Inovasi Pendidikan dan Kreatifitas Pemebelajaran di Perguruan Tinggi. Konverensi Nasional Ekonomi Manajemen dan Akuntansi (IKNEMA) 2020. Universitas Muhammadiyah Jakarta 10-11 Desember 2020.

Hidayatullah, M Furqan, 2010. Pendidikan Karakter. Membangun Pendidikan Bangsa. Surakarta. Yuma Pustaka. Mahmud (2017). Pendidikan Karakter Konsep dan Implementasi. Jakarta. Alfabeta 


\section{PEMBELAJARAN AGAMA ISLAM PASCAPANDEMIC DI UNIT PELAKSANA TEKNIS MATAKULIAH PENGEMBANGAN KEPRIBADIAN UNIVERSITAS SRIWIJAYA}

\section{Abdul Gafur.S.S., M.Pd.I² \\ Universitas Sriwijaya}

"Seorang pendidik harus mencari strategi yang tepat pasca pandemic seperti menggunakan metode blanded learning metode ini bisa mengatasi kejemuhan peserta didik selama ini yang sudah lebih dua tahun dengan metode daring"

$\mathrm{P}$ endidikan Agama Islam merupakan suatu upaya terstruktur dan terencana untuk menyiapkan anak untuk mengetahui, memahami, menghayati, hingga mengimani serta mengimplemtansikan ajaran agama Islam dalam kehidupan sehari hari. Seyogianyalah Pendidikan Agama Islam ditanamkan dalam pribadi anak sejak lahir bahkan sejak dalam kandungan dan dilanjutkan pembinaan pendidikan ini di sekolah, mulai dari taman kanak-kanak sampai dengan perguruan tinggi.

2Penulis lahir di Seribandung, 09 November 1979, penulis merupakan Dosen Universtas Sriwijaya Palembang dalam bidang ilmu Pendidikan Agama Islam, penulis menyelesaikan gelar Sarjana Sastra Arab di Institut Agama Islam Negeri Raen Fatah Palembang (2002), gelar Sarjana Sastra Arab di Fakultas Adab IAIN Raden Fatah Palembang, sedangkan gelar Magister Pendidikan Pendidikan Agama Islam diselesaikan di Universitas Islam Negeri Raden Fatah Palembnag Program Studi Ilmu Pendidikan Islam (2009), Sekarang lagi menempuh program Doktoral di UI Raden Fatah Palembang. 
Bagi masyarakat muslim, pendidikan agama islam wajib diikuti, walaupun saat ini muncul isu yang beredar melalui berita atau media sosial bahwa dalam Peta Jalan Pendidikan Nasional (PJPN) 2020-2035 yang di luncurkan oleh kemendikbud bahwa prase agama akan di ganti dengan kata akhlak dan budaya (https://www.riauonline.co.id/riau/kotapekanbaru/read/2021/03/10/frasa-agama-dihapus-daripeta-jalan-pendidikan-nasional-kata-zulkarnain) hal ini banyak menimbulkan kecaman dan reaksi dari masyarakat karena pendidikan agama sangat penting untuk menjaga kekokohan beragama siswa.

Dalam proses pembelajarannya banyak hal yang mempengaruhi baik faktor ekteren, interen dan lingkungan belajar yang tidak bisa di pisah pisahkan, seperti keadaan jasmani dan rohani, faktor eksternal yakni kondisi lingkungan sekitar anak (sosial dan non sosial) serta faktor pendekatan belajar, yakni upaya belajar yang meliputi strategi dan metode yang digunakan untuk melakukan kegiatan pembelajaran secara efektif dan efisien.

Namun semenjak Maret 2020 karena adanya wabah covid 19 menuntut kepada seorang pendidik untuk mencari formulasi metode pembelajaran yang pas sehingga dalam tujuan pembelarannya dapat di lakukan dengan sebaik mungkin begitu pun peserta didik dapat memahami apa yang di sampaikan oleh pendidik. Karena persepsi peserta didik, orang tua dan pendidik berbeda dalam menanggapi pembelajaran selama masa pandemi (Jingwen Xie, Minhong Wang, Danial Hoosyar, 142-160).

Pandemi ini membawa dampak ( Rebecca S. Cottrell, 2021) pada tatanan kehidupan baik bidang ekonomi, sosial kemasyarakatan, keagamaan, kesehatan, transportasi 
bahkan dunia pendidikan (Fajar, webinar, DarlingHammond \& Hyler, 2020; García-- Peñalvo, Corell, RiveroOrtega, dkk., 2021; Hadar dkk., 2020) walau pun dari pembelajarannya tidak ada perbedaan yang signifikan antara pembelajaran daring dan luring (Rebecca S. Cottrell, 2021), ada di temukan hasil belajar siswa ada yang lebih baik antara pembelajaran tatap muka dengan on line (Arias, Swinton, \& Anderson, 2018). Pada dasarnya pendidikan pun belum mengakomodasi situasi tersebut, karena ini merupakan situasi dimana terjadi disparitas antara satu sekolah dengan sekolah lain dan kebanyakan guru - guru yang belum siap melakukan pembelajaran online secara mandiri. Begitu pun siswa yang belum memiliki perangkat komunikasi, orang tua belum terbiasa dengan pembelajaran online, serta kurikulum padat tidak mungkin diterapkan seluruhnya selama masa pandemi. Diperlukan konstruksi kurikulum yang relevan dengan situasi pandemi maupun pascapandemi. Karena kita membutuhkan kurikulum era pandemi yang adaptif dengan perubahan global. Hal ini di sampaikan oleh Reza Fahlevi selaku pelaksana tugas harian diknas pendidikan provinsi sumatera selatan dalam webinar 11 juni 2020. Selama pembelajaran masa covid ini berdampak juga pada peserta didik (Suzanne Ensmann, dkk, 2021) seperti pada masalah keuangan, jadwal pembelajaran yang tumpang tindih dan sumber daya teknologi. Ada tingkah laku peserta didik selama proses pembelajaran on line ini sangat bervariasi (David C.D. van Alten *, Chris Phielix, Jeroen Janssen, Liesbeth Kester (1-13). Walaupun dampak COVID-19 terhadap pelaksanaan pembelajaran online di sekolah dasar ada juga yang terealisasi secara baik, namun harus saling kerjasama antara guru, orang tua dan siswa (Lita Puspita Sari, 2019). 
Ada hal yang dialami pendidik dalam pembelajaran daring seperti strategi yang belum pas, kurang menguasai teknologi yang hanya menggunakan WhatsApp, cara penilaian (sikap, pengetahuan, keterampilan) yang kurang tepat, begitupun siswa kurang fasilitas, adanya gangguan koneksi internet sehingga hal tersebut menghambat proses pembelajaran daring, begitupun paket data dari Kemendikbud tidak dapat digunakan, pendidik tidak bisa menilai secara langsung kelemahan dan kelebihan peserta didik, tugas pendidik berikan kebanyakan dikerjakan oleh orang tua (Astri Rahmawati, Elta Al Pina, Panut Setiono, Nani Yuliantini, Wurjinem, 2021)

Selain berdampak negatif namun juga wabah ini memberikan dampak yang positif di antaranya bidang kesehatan, telekomukasi, teknologi informasi, usaha makanan dan minuman (Fajar, Webinar), sebagai contoh bidang teknologi komunikasi diantara dunia telekomunikasi harus mengembangkan aflikasi dan system informasi yang di butuhkan masyarakat, mengembangkan infrasturktus elearning di kampus dan sekolah, memperbesar manfaat penggunaan IT dalam dunia pendidikan serta menggeser pemanfaatan dunia hiburan media sosial menjadi dunia pendidikan. (Fajar). Begitupun dalam pembelajaran pendidikan Agama Islam di Universitas Sriwijaya di masa wabah ini di perlukan strategi maupun metode yang pas sehingga apa yang diharapkan tercapai. Hal ini senada dengan apa yang di katakan oleh Marzuki Ali dalam Webinar Sabtu, 13 juni 2020 bahwa pendidik harus mampu memilih bahkan menciptakan metode, media dan materi terbaru yang bisa di gunakan untuk pembelajaran daring ini. 
Metode yang telah di gunakan pada akhir maret 2020 menggunakan metode Daring dan Luring, sebagaimana himbuan yang telah disampaikan pihak rektorat universitas sriwijaya. Sebagai contoh metode yang di pakai menggunakan Luring yakni metode resitasi yakni memberikan tugas kepada mahasiswa berupa Tugas Mandiri atau pun tugas menghafal surah surah yang pendek. Pembelajaran Daring dapat dilakukan melalui aplikasi zoom (Khasana, Siti Uswatun, Syarifah, Ainun. 2021) ataupun WA group. Walaupun dalam pelaksanaan nya masih banyak problem, diantaranya peserta didik merasa sulit untuk memahami materi pembelajaran, tidak merasa termotivasi untuk belajar dan tidak menguasai pembelajaran dengan baik (Annisa Nurul Fadilla, Ayu Suci Relawati, Nani Ratnaningsih, 2021) Oleh karena itu peserta didik harus di berikan motivasi karena motivasi dianggap sebagai faktor penting untuk keberhasilan belajar termasuk dalam lingkungan belajar daring (Yani Fitriyani, Irfan Fauzi, Mia Zultrianti Sari. 2020) dan semangat serta keterampilan khusus untuk menyiapkan peralatan yang di gunakan selama pembelajaran daring (Martin et al., 2020, hlm. 54).

Kendala yang di temukan di lapangan yakni bermacammacam baik pada mahasiswa ataupun dosen sendiri. Mahasiswa di anjurkan untuk pulang kumpul dengan orang tua mereka masing-masing ada yang di kampung halaman atau pun ada yang di kota. Keberadaan mereka di desa terkait ketika perkuliahan daring jelas mengalami hambatan terkait jaringan internet belum lagi mereka harus menyiapkan tambahan dana untuk beli paket internet dalam menunjang pembelajaran, terkadang ada uang untuk beli paket namun jaringan internet yang sangat susah mereka dapatkan. Sehingga ini terkadang menghambat 
perkuliahan hal ini juga di temukan ketika mengumpul tugas mandiri yang terlambat karena jaringan internet yang sangat susah. Sama halnya yang dialami dosen terkadang harus menambah jatah belanja uang paket internet. Antara pendidik, peserta didik dan orang tua maupun peran teknologi serta lembaga pendidikan sangat erat hubungannya untuk mendapatkan hasil yang memuaskan semua pihak dalam pembelajaran daring (Gregory E. Blundell and Daniel A. Castañeda Junghyae Lee, 2020). Karena itu perlu usaha untuk mengatasi cara pembelajaran yang tepat oleh semua pihak karena kondisi yang tidak stabil. Bagi pendidik ketahanan daring sangat tepat di massa Covid-19, karena pedidik memiliki peran yang besar untuk kelancaran pembelajaran daring (Aliet Noorhayati Sutisno, Dewi Nurdiyanti, 2020).

Begitu juga yang terjadi pada pembelajaran pendidikan agama islam di Unit Pelaksana Teknis Matakuliah Pengembangan Kepribadian Universitas Sriwijaya, pada masa pandemic dan pasca pandemi. Seorang pendidik harus mencari juga strategi yang tepat pasca pandemic ini walaupun pemerintah sendiri masih mengingatkan untuk tetap waspada akan pandemic ini sehingga pembelajaran pasca pandemic ini menggunakan metode blanded learning yakni perpaduan antara metode $50 \%$ daring dan luring $50 \%$. Tentunya dengan metode ini bisa mengatasi kejemuhan peserta didik selama ini yang sudah lebih dua tahun dengan metode daring / belajar di rumah, yang memiliki kekurangan dan kelebihan masing masing, begitu pun pendidik sendiri untuk lebih memudahkan mengetahui kemampuan mahasiswa harapannya bisa dilakukan.dengan metode ini. 


\section{Daftar Pustaka}

Arias, J. J., Swinton, J., \& Anderson, K. (2018). Online vs. face-to-face: A comparison of student outcomes with random assignment. E-Journal of Business Education and Scholarship of Teaching, 12(2), 1-23.

Blundell, G.E., Castañeda, D.A., \& Lee, J. (2020). A multiinstitutional study of factors influencing faculty satisfaction with online teaching and learning. Online Learning, 24(4), 229-253. https://doi.org/10.24059/olj.v24i4.2175.

Cottrell, R. (2021). Student performance in online classes at a Hispanic-Serving Institution: A study of the impact of student characteristics in online learning. Online Learning, 25(3), 18-35. doi:10.24059/olj.v25i3.2853.

Darling-Hammond, L., \& Hyler, M. (2020). Preparing educators for the time of COVID... and beyond. European Journal of Teacher Education.

https://doi.org/10.1080/02619768.2020.1816961

Ensmann, S., Whiteside, A., Gomez-Vasquez, L., \& Sturgill, R. (2021). Connections before curriculum: The role of social presence during COVID-19 emergency remote learning for students. Online Learning, 25(3), 36-56. doi: 10.24059/olj.v25i3.2868

Fadilla, A. N., Relawati, A. S., \& Ratnaningsih, N. (2021). Problematika Pembelajaran Matematika Daring Di Masa Pandemi Covid-19. Jurnal Jendela Pendidikan, 01 (02), 4860.

Fitriyani, Y., Fauzi, I., \& Sari, M. (2020). Motivasi Belajar Mahasiswa Pada Pembelajaran Daring Selama Pandemik Covid-19. Jurnal Kependidikan: Jurnal Hasil Penelitian dan Kajian Kepustakaan di Bidang Pendidikan, Pengajaran dan 
Pembelajaran,

175).doi:https://doi.org/10.33394/jk.v6i2.2654.

García-Pẽnalvo, F. J., Corell, A., Rivero-Ortega, R., Rodríguez-Conde, M. J., \& Rodríguez-García, N. (2021). Impact of the COVID-19 on higher education: An experiencebased approach. In F. J. García-Pe nalvo (Ed.), Information technology Trends for a global and Interdisciplinary research community (pp. 1-18). IGI Global. https://doi.org/10.4018/978-1-7998-4156-2.ch001.

Hadar, L., Ergas, O., Alpert, B., \& Ariav, T. (2020). Rethinking teacher education in a VUCA world: Student teachers' social-emotional competencies during the covid19 crisis. European Journal of Teacher Education. https://doi.org/10.1080/02619768.2020.1807513

Khasana, Siti Uswatun, Syarifah, Ainun. (2021). Persepsi Mahasiswa Pendidikan Bahasa Inggris UIN Sunan Ampel Surabaya Terhadap Pembelajaran Daring Via Zoom Pada Masa Pandemi Covid-19. Edunesia; Jurnal Ilmu Pendidikan. Vol. 2 No.1

Martin, F., Stamper, B., \& Flowers, C. (2020). Examining student perception of their readiness for online learning: Importance and confidence. Online Learning Journal, 24(2), 38-58. https://doi.org/10.24059/olj.v24i2.2053.

Means, B., \& Neisler, J. (2021). Teaching and learning in the time of COVID: The student perspective. Online Learning, 25(1), 8-27. https://doi.org/10.24059/olj.v25i1.2496.

Noorhayati Sutisno, Aliet. Dewi Nurdiyanti. (2020). Sistem Daring Pembelajaran Jarak Jauh Sebagai Realisasi Merdeka Belajar di Masa Pandemi. Dwija Cendikia: Jurnal Riset Pedagogik. 4 (2). 265 - 273). 
Puspita Sari, L. (2019). Konsep Pembelajaran Daring Di Tengah Pandemi Covid-19. Equivalent: Jurnal Ilmiah Sosial Teknik. Vol. 1, No. 2, Juli 2019

Rahmawati, Astri, dkk. (2021). Kesulitan Guru Dalam Pembelajaran Tematik Di Kelas V Sd Negeri 38 Kota Bengkulu Selama Pembelajaran Daring. Elementary School 8 Vol 8, No 2): Jurnal Pendidikan dan Pembelajaran Ke-SDan). $303-309$.

Xie, Jingwen, Minhong Wang, Danial Hoosyar. (2021) Student, parent, and teacher perceptions towards digital educational games: How they differ and influence each other. Knowledge Management \& E-Learning: An International Journal (KM\&EL)ISSN 2073-7904. 13(2), 142160. https://doi.org/10.34105/j.kmel.2021.13.008 
Menyongsong PTMT Pada Dunia Pendidikan 


\title{
EKSPLORASI MATA KULIAH \\ PRAKTIK PASCA PANDEMI
}

\author{
Hetilaniar, M.Pd. ${ }^{3}$ \\ Universitas PGRI Palembang
}

\begin{abstract}
“Keberuntungan pembelajaran tatap muka membuka keleluasaan untuk melaksanakan mata kuliah yang seharusnya memang dilakukan praktik"
\end{abstract}

etelah melalui masa pandemi, kini dunia pendidikan
mulai memasuki pembelajaran tatap muka terbatas. Awal masuknya pandemi ini di Indonesia mengubah semua kegiatan dalam pendidikan terutama dalam proses belajar mengajar. Baik tingkat sekolah maupun Perguruan Tinggi. Semula pembelajaran dilakukan secara tatap muka, dengan kehadiran pandemi diubah secara cepat dengan pembelajaran dalam jaringan (daring). Memasuki era new normal pasca pandemi secara perlahan proses pembelajaran kembali seperti semula namun dilaksanakan secara terbatas. Perguruan Tinggi mempunyai mata kuliah praktik yang memang harus dilakukan secara tatap muka

3Hetilaniar, M.Pd. kelahiran Jepara, 13 Desember 1981 menamatkan pendidikan S1 Pendidikan Bahasa dan Sastra Indonesia FKIP Universitas PGRI Palembang pada tahun 2006. Tahun 2011, ia terdaftar sebagai mahasiswa pascasarjana program magister pendidikan Bahasa dan Sastra Indonesia FKIP Universitas PGRI Palembang, tamat tahun 2013. Kini ia sebagai dosen tetap di Program S1 Pendidikan Bahasa Indonesia FKIP Universitas PGRI Palembang yang memiliki tugas tambahan sebagai Ketua Program Studi Pendidikan Bahasa Indonesia FKIP Universitas PGRI Palembang. 
untuk mendapatkan hasil yang maksimal. Perlu penjelajahan atau eksplorasi untuk mata kuliah praktik pasca pandemi saat ini, langkah ini sangat berguna untuk mengukur tingkat pemahaman dan keberhasilan mahasiswa dalam mengikuti mata kuliah yang harus dilaksanakan secara praktik langsung di sanggar atau laboratorium yang mendukung kegiatan praktikum tersebut.

Program Studi Pendidikan Bahasa Indonesia FKIP Universitas PGRI Palembang, pasca pandemi saat ini sedang melaksanakan kegiatan praktik mata kuliah seperti mata kuliah pewara, teori dan apresiasi puisi serta mata kuliah drama. Dalam kegiatan praktik dilaksanakan di Sanggar Bastra Universitas PGRI Palembang. Sanggar adalah suatu tempat atau sarana yang digunakan oleh suatu kelompok atau sekumpulan orang untuk melakukan suatu kegiatan (pratikum). Selama ini suatu tempat dengan nama "sanggar" biasa digunakan untuk kegiatan-kegiatan berkelompok yaitu sanggar ibadah, sanggar seni, sanggar kerja dan sanggar anak (Aina, Kurnita, \& Zuriana, 2017, p. 164). Sanggar bahasa dan sastra Indonesia memiliki ciri-ciri individu atau perorangan. Sehubungan dengan fungsi individu atau perorangan tersebut, sanggar bahasa dan sastra Indonesia memiliki fungsi ekspresif, regulasi, referensi, heuristik, estetis, dan kreatif. Sanggar bahasa Indonesia dan sastra dapat digunakan untuk mengekspresikan sesuatu. Ungkapan ini terutama dalam bentuk ekspresi linguistik dan sastra. Selain itu, dosen dan mahasiswa dapat mengungkapkan sebuah pikiran, gagasan, perasaan, keinginan, kekecewaan, informasi melalui praktik pewara, teori dan apresiasi puisi serta drama. Pembelajaran tatap muka sangat dinantikan oleh para dosen dan mahasiswa dalam melaksanakan praktikum mata kuliah. 
Mata kuliah seperti yang sudah dijelaskan di atas memang membutuhkan pembelajaran tatap muka. Dalam praktik mata kuliah pewara, harus disampaikan secara langsung oleh dosen melalui pembelajaran tatap muka karena pewara berkaitan dengan vokal yang harus bagus sehingga diperlukan latihan untuk olah vokal.

Pembawa acara atau pranatacara merupakan orang yang pertama kali berbicara dalam memandu sebuah acara. Jalan tidaknya suatu acara tergantung pembawa acara atau pranatacara dapat membawa penonton merasa tertarik dengan apa yang diucapkan oleh pembawa acara. Jadi, kesuksesan suatu acara tertetak pada pembawa acara atau pranatacara dalam memandu acara (Ula, Santoso, \& Winarsih, 2020, p. 54). Dalam pewara mempunyai beberapa persyaratan yang harus dimiliki yaitu berpenampilan yang menarik, mempunyai rasa percaya diri, memiliki kemampuan berbicara yang baik, mempunyai wawasan dan pengetahuan yang luas, memiliki selera humor yang tinggi dan mempunyai bahasa tubuh yang mengesankan (Laksmi, 2011, p. 41). Pada pembelajaran tatap muka dosen lebih leluasa dalam menyampaikan materi dan latihan secara langsung di Sanggar Bastra. Melalui pembelajaran tatap muka mata kuliah yang harus dilaksanakan secara praktik saat ini sudah berjalan dengan baik dan sesuai dengan harapan. Mahasiswa bebas dalam berekspresi, berlatih vokal bersama dosen dan mahasiswa yang lainnya. Bisa bertindak langsung, bisa bertanya langsung dan dosenpun bisa melihat perkembangan mata kuliah pewara ini serta bisa memahami karakter vokal masing-masing mahasiswa. Pembelajaran tatap muka untuk mata kuliah praktikum memang sangat menyenangkan, ketika praktik pewara dilakukan secara tatap muka maka dosen bisa secara 
langsung mengawasi mahasiswa baik dari vokal maupun dari penampilan (busana) dalam praktik pewara. Jadi, banyak sekali keuntungan dalam pembelajaran tatap muka untuk mata kuliah praktik. Selanjutnya, mata kuliah yang harus dipraktikkan adalah mata kuliah teori dan apresiasi puisi. Mata kuliah ini memadukan antara teori dan praktik, pembelajaran tatap muka sangat penting untuk mata kuliah teori dan apresiasi puisi karena proses dari mata kuliah ini akan lebih efektif jika dilaksanakan secara tatap muka. Setelah menyampaikan teori tentang puisi, dosen akan melaksanakan praktik menulis dan membaca puisi. Mata kuliah teori dan apresiasi puisi dipraktikkan langsung di Sanggar Bastra Universitas PGRI Palembang. Setelah mahasiswa sudah memahami secara teori maka perlu praktik untuk mata kuliah ini. Jika pembelajaran dilaksanakan tatap muka, maka tidak ada penghalang dalam menyampaikan materi dan melaksanakan praktik. Menurut Nurhadi (Hetilaniar \& Auliya, 2019, p. 162) puisi adalah karya sastra yang menggabungkan gagasan penyair dalam bahasa yang ringkas dan padat, menggunakan irama suara yang konsisten dan pemilihan kata kiasan (imajinasai). Sehingga dalam praktiknya mahasiswa perlu memilih kata imajinasi yang tepat, vokal dan penghayatan yang sesuai.

Pembelajaran tatap muka sangat penting untuk mata kuliah teori dan apresiasi puisi. Mahasiswa bisa menerapkan apa yang didapatkan melalui teori yang telah disampaikan oleh dosen. Sehingga secara tatap muka bisa mengolah vokal bersama, menuangkan imajinasi dan kreativitas untuk menyampaikan ide dalam menulis puisi, bisa bertukar pikiran langsung dengan teman satu kelas, bisa bebas dalam mengekspresikan puisi yang sudah dibuat dan secara langsung dalam pembelajaran tatap muka bisa 
melihat pembacaan puisi mahasiswa satu dengan yang lainnya, untuk itu dapat saling bertukar pendapat. Praktik mata kuliah puisi memang membutuhkan pembelajaran luar jaringan atau tatap muka agar tersampaikan dengan baik dan bisa menghasilkan sesuatu yang maksimal. Praktik mata kuliah ini diawali dengan latihan olah vokal, olah tubuh dan membaca puisi yang sudah disiapkan. Dari latihan ini dosen bisa melihat kesesuaian vokal dan penghayatan serta ekspresi dari mahasiswa. Jadi mahasiswa tidak hanya dibekali dengan teori namun juga praktik.

Begitu juga mata kuliah drama sangat penting jika dilakukan secara tatap muka. Drama adalah karya sastra yang ditulis oleh seseorang dan dipentaskan di panggung (Hetilaniar \& Murniviyanti, 2021, p. 145). Perwujudan drama adalah kehadiran unsur-unsur yang terletak di luar jangkauan kata-kata dan harus dilihat sebagai peran (Emzir \& Rohman, 2017, p. 262). Pada mata kuliah praktik drama juga harus dilaksanakan secara tatap muka karena ini berkaitan dengan peran atau lakon untuk itu pembelajaran luar jaringan sangat penting untuk melaksanakan praktik mata kuliah drama. Secara langsung dosen akan melihat proses latihan drama yang dilakukan oleh mahasiswa. Dari latihan olah vokal, latihan olah tubuh, latihan olah mimik, latihan memahami naskah, melafalkan isi naskah dengan didukung ekspresi yang sesuai dan penghayatan yang tepat. Pertama, dosen menjelaskan secara teori kepada mahasiswa. Kedua, dosen memberikan tugas kepada mahasiswa untuk menulis atau mencari naskah drama yang menarik dan belum dipentaskan. Ketiga, dosen melihat satu persatu naskah drama yang sudah disiapkan oleh mahasiswa. Keempat, dosen akan memilih naskah yang menarik dan kekinian. Kelima setelah naskah terpilih, 
dilakukan latihan drama ini di Sanggar Bastra Universitas PGRI Palembang.

Proses latihan drama memerlukan waktu yang cukup panjang agar menjadi sebuah pementasan. Dalam hal ini mahasiswa perlu berlatih secara berulang-ulang untuk memahami karakter dalam naskah drama. Tidak mudah menjadi orang lain, maka dari itu butuh proses yang cukup panjang untuk menjiwai karakter yang ada dalam naskah drama. Dalam hal ini dilihat bahwa begitu penting pembelajaran tatap muka untuk ketercapaian mata kuliah parktik ini. Dosen bisa secara bebas melihat proses latihan dan ekspresi mahasiswa jika dilakukan secara tatap muka. Banyak kegiatan positif yang didapatkan dari pembelajaran tatap muka ini.

Berbagai kegiatan praktik mata kuliah di Program Studi Pendidikan Bahasa Indonesia FKIP Universitas PGRI Palembang dilaksanakan di Sanggar Bastra. Pemanfaatan sanggar Bastra sangat aktif saat berlangsungnya pembelajaran tatap muka. Sanggar Bastra merupakan tempat mahasiswa untuk menggali potensi dan kreativitas melalui praktik mata kuliah pewara, teori dan apresiasi puisi serta drama. Bukan hanya itu Sanggar Bastra juga merupakan wadah bagi mahasiswa untuk mengembangkan minat dan bakat yang dimiliki. Keberuntungan pembelajaran tatap muka ini membuka keleluasaan untuk melaksanakan mata kuliah yang seharusnya memang dilakukan praktik.

\section{Daftar Pustaka}

Aina, J., Kurnita, T., \& Zuriana, C. (2017). Bentuk Penyajian Tari Linggang Meugantoe di Sanggar Rampoe Banda Aceh. Jurnal Ilmiah Mahasiswa Program Studi Pendidikan Seni 
Drama, Tari dan Musik Fakultas Keguruan dan Ilmu Pendidikan Unsyiah, II (2), 164.

Emzir, \& Rohman, S. (2017). Teori dan Pengajaran Sastra. Depok: Rajawali Pers.

Hetilaniar \& Murniviyanti, L. (2021). Kelayakan Modul Pementasan Monolog Metode Role Playing dan Teknik 3M. Kredo, (1), 145.

Doi:

https://doi.org/10.24176/kredo.v5i1.6017

Hetilaniar, \& Auliya, D. (2019). Pengaruh Strategi Jumput Terhadap Kemampuan Membaca Puisi Siswa Kelas X SMA Negeri 10 Palembang. Wahana Didaktika, 17 (2), 162. Doi: http://dx.doi.org/10.31851/wahanadidaktika.v17i2.2499 Laksmi, A. R. (2011). Mengenal Pewara dan Protokol. Singhadwala, 41.

Ula, M., Santoso, A. B., \& Winarsih, E. (2020). Penggunaan Bahasa Pembawa Acara Pernikahan di Wilayah Madiun. Widyabastra, 8 (1), 54. 
Menyongsong PTMT Pada Dunia Pendidikan 


\section{OPTIMALISASI PEMBANGUNAN KOMPETENSI LITERASI DALAM PEMBELAJARAN BAHASA INDONESIA}

\section{Putri Wulan Dhari, M.Pd. 4 \\ IAIN Takengon}

“Tidak hanya guru dan sekolah yang bertanggung jawab dalam mengemban amanah meningkatkan mutu generasi masa depan, tetapi juga dukungan dari orang tua, pemerintah, dan stakeholder ikut mempengaruhi hasil akhir dalam pembangunan kompetensi literasi pada siswa"

$\mathrm{P}$ ada hakikatnya, pembelajaran bahasa Indonesia yang dilaksanakan di sekolah bertujuan untuk membimbing, mengarahkan, meningkatkan, dan memantau perkembangan kemampuan berbahasa siswa melalui empat keterampilan, yaitu menyimak, berbicara, membaca, dan menulis. Melalui keterampilan ini, siswa dituntut dan didorong untuk belajar memakai bahasa, belajar mengenai bahasa, dan belajar melalui bahasa (Atmazaki, 2013:16). Dapat dikatakan tujuan akhir yang diharapkan melalui pembelajaran Bahasa Indonesia adalah agar siswa mampu berkomunikasi dengan baik dan benar sesuai dengan

4Penulis berasal dari Takengon, Aceh, kelahiran Bireuen, 23 Maret 1989. Saat ini, penulis merupakan dosen Bahasa Indonesia di IAIN Takengon. Gelar Sarjana Pendidikan Bahasa, Sastra Indonesia dan Daerah diperoleh penulis dari Universitas Negeri Medan (2012), kemudian dilanjutkan dengan Magister Pendidikan Bahasa Indonesia yang diselesaikan di Universitas Sebelas Maret Surakarta (2014). 
konteksnya, dapat mengekpresikan gagasan dan perasaan dengan cara yang efektif dan efisien, meningkatkan kemampuan siswa dalam berpikir dan bernalar, serta menghargai dan bangga pada bahasa dan sastra Indonesia.

Untuk mengejawantahkan tujuan pembelajaran di atas, kurikulum 2013 sebagai arah dan pedoman pelaksanaan pendidikan menekankan pembelajaran berbasis teks pada Bahasa Indonesia. Melalui pembelajaran Bahasa Indonesia berbasis teks, siswa tidak hanya diharapkan dapat meningkatkan kemampuannya berkomunikasi, melainkan juga dapat mengembangkan kemampuan mental dan berpikir kritisnya sehingga mereka lebih siap dalam menghadapi berbagai masalah dalam kehidupan nyata (Khair, 2018:90). Lebih lanjut lagi, Mahsun dalam sumber kutipan yang sama menyebutkan bahwa terdapat dua perihal penting dalam pembelajaran Bahasa Indonesia berbasis teks, yaitu makna dan bentuk, yang mana unsur makna merupakan prioritas utama sebagai pembentuk bahasa dan pada akhirnya sebagai sarana penciptaan pikiran. Oleh karena itu, dalam belajar bahasa, guru harus menyadari bahwa kemampuan siswa harus diarahkan pada kemampuan berpikir yang sistematis, empiris, kritis, dan terkontrol.

Melanjuti paragraf di atas, salah satu upaya yang harus dilakukan guru untuk meningkatkan kemampuan berpikir dan bernalar siswa adalah dengan membangun generasi literat. Ihwal ini memiliki relevansi erat dengan selah satu peran pembelajaran Bahasa Indonesia sebagai penbentuk kompetensi literasi. Pembelajaran Bahasa Indonesia berbasis teks saat ini pada esensinya juga sebagai ikhtiar pemerintah untuk membentuk siswa literat. Dalam pembelajaran berbasis teks, siswa akan dituntut dan 
dipaksa untuk belajar membaca dan menulis secara kontinu sehingga diharapkan mereka akan memiliki kemampuan membaca dan menulis dengan baik dan pada akhirnya akan meningkatkan kemampuan berliterasi pula. Susasnto (2016:13) menyebutkan siswa yang dapat digolongkan sebagai generasi literat adalah mereka yang memiliki kemampuan dalam mengerti dan memahami informasi dari sebuah bacaan, kemudian menerapkan informasi tersebut dalam kehidupan nyata.

Hasil belajar bahasa Indonesia yang berupa kecakapan siswa dalam membaca dan menulis secara tidak langsung akan turut menghasilkan kecakapan informasi. Kecakapan ini tentu tidak hanya bermanfaat dalam pembelajaran Bahasa Indonesia, tetapi juga dalam berbagai pembelajaran lainnya karena seyogianya, mata pelajaran apa pun akan memaksa siswa untuk menguasai dan mengamalkan berbagai informasi yang diperoleh melalui kegiatan membaca dan menulis.Kecakapan informasi merujuk pada beberapa aktivitas, yakni mengumpulkan, mengolah, dan mengomunikasikan informasi. Ketiga aktivitas ini akan terus berjalan beriringan dengan keterampilan membaca dan menulis (Subandiyah, 2015:113). Dengan demikian, kompetensi literasi yang dimiliki siswa akan bepengaruh terhadap tingkat pengetahuan dan keterampilannya sehingga hal ini harus terus diupayakan untuk dapat dibangun dan dikembangkan secara optimal.

Sayangnya, urgensi kemampuan literasi tidak sejalan dengan kenyataan saat ini. Hal ini dapat dibuktikan melalui banyaknya penelitian, seperti yang dilakukan UNESCO, PISA, dan Perpusnas (Fahmy dkk, 2021:122). UNESCO menyatakan bahwa Indonesia menempati posisi cukup rendah dalam hal literasi. Sejalan dengan itu, PISA (Program 
for International Student Assesment) menyebutkan Indonesia berada pada peringkat 72 dari 77 negara pada kategori membaca. Pepurnas masih memberikan hasil penelitian yang lebih baik dari dua lainnya, yang menghasilkan minat baca Indonesia berada dalam kategori sedang.Mengacu pada beberapa hasil penelitan di atas, tentu harus diyakini bahwa minat baca di Indonesia masih jauh dari harapan.

Kompetensi literasi siswa yang optimal tentu akan sulit dicapai jika keadaan ini terjadi berkepanjangan. Apalagi dengan terjadinya pandemi covid-19 di Indonesia, situasi ini menjadi semakin genting untuk dicari solusinya. Keterbatasan-keterbatasan yang muncul karena pandemi menyebabkan banyak kerugian dalam pelaksanaan aktivitas literasi di sekolah, antara lain; (1) pembelajaran terpaksa dilakukan secara daring sehingga menyebabkan aktivitas membaca dan menulis menjadi tidak terpantau maksimal; (2) perpustakaan sebagai salah satu sarana dalam membantu siswa berliterasi juga tidak dibuka; penggunaan gawai sebagai alat utama dalam pembelajaran daring malah menjadi masalah baru bagi siswa, seperti ketergantungan gawai; dan (4) minat baca siswa yang sebelumnya disebut rendah menjadi semakin rendah sejak pandemi yang menyebabkan maraknya kepercayaan terhadao informasi palsu atau hoaks.

Dengan demikian, sekolah perlu mengupayakan berbagai solusi yang dapat mengoptimalkan aktivitas literasi, khususnya dalam pembelajaran Bahasa Indonesia. Saat ini, banyak sekolah di berbagai daerah telah melakukan pembelajaran tatap muka terbatas. Kembalinya siswa dalam pembelajaran tatap muka merupakan salah satu langkah awal untuk kembali menggalakkan semangat berliterasi 
pada siswa. Beberapa upaya yang dapat dilakukan guna membangun dan meningkatkan kemampuan literasi siswa dalam pembelajaran tatap muka terbatas adalah sebagai berikut.

Pertama, membentuk Gerakan Literasi Sekolah (GLS). GLS adalah gerakan yang berupaya untuk meliterasikan seluruh warga sekolah, baik kepala sekolah, guru, siswa, maupun orang-orang yang terkait di dalamnya, seperti orang tua siswa dan komite sekolah sehingga diharapkan melalui gerakan ini akan terbentuk generasi literat (Juminingsih, 2019:57). Ada beberapa tahap yang dapat dilakukan sekolah saat mengimplementasikan GLS seperti yang disebutkan Anderson, yaitu tahap pembiasaan, pengembangan, dan pengajaran (Sadli dan Saadati, 2019:158-159). Dalam implementasinya, sekolah dapat melakukan rutinitas yang berkaitan dengan aktivitas literasi, misalnya membaca 15 menit sebelum jam pelajaran, mengaktifkan kembali perpustakaan sebagai sarana yang kaya literasi, membuat sudut baca, mading, membaca dongeng, dan pemutaran film pendek yang mengandung nilai-nilai pendidikan. Sekolah dapat melibatkan guru bahasa Indonesia dan guru-guru lain agar kegiatan-kegiatan ini dapat berjalan optimal.

Selain adanya perpustakaan dan mading, sekolah juga bisa mempertimbangkan untuk membuat sudut baca yang ditempatkan di sudut ruangan kelas dan dilengkapi dengan berbagai bacaan. Kemendikbud (dalam Hartyatni, 2018:3) menyebutkan bahwa sudut baca dapat digunakan sebagai perpanjangan fungsi perpustakaan. Dengan adanya sudut baca, siswa akan dibiasakan membaca buku dengan cara yang lebih menyenangkan, dapat dilakukan di sela-sela senggang sekolah atau untuk dipinjam. Adanya sudut baca 
bukan hanya dapat membuat siswa meningkatkan minat bacanya, melainkan juga dapat meningkatkan minat menulisnya. Siswa dapat meningkatkan imajinasinya lewat kegiatan membaca sehingga mereka akan lebih tertarik untuk menulis setelahnya. Di sini, peran penting guru bahasa Indonesia sangat diperlukan dalam membimbing dan mengarahkan siswa untuk mencapai tujuan yang diharapkan.

Kedua, guru bahasa Indonesia secara aktif dan kreatif menyediakan berbagai sumber belajar yang relevan dengan materi yang dipelajari siswa, baik sumber cetak maupun noncetak. Semakin bervariasi sumber belajar yang digunakan siswa dalam aktivitas membaca dan menulis, siswa akan semakin mudah untuk mendapatkan informasi yang lebih detail. Selain itu, sumber belajar yang bervariasi akan membuat kegiatan pembelajaran semakin menarik dan tidak membosankan. Beberapa sumber belajar yang dapat digunakan guru dalam kegiatan literasi misalnya buku, koran, majalah, surat kabar, artikel, radio, video, narasumber ahli, dan benda-benda lainnya.

Ketiga, guru bahasa Indonesia juga dapat menggunakan berbagai metode, strategi, dan model pembelajaran bervariasi yang dapat meningkatkan kompetensi literasi siswa. Dalam hal ini, Subandiyah (2015:114) menjelaskan bahwa model pembelajaran kooperatif lebih efektif untuk digunakan karena lebih memprioritaskan kerja sama kelompok dalam memecahkan masalah. Beberapa metode, strategi, dan model pembelajaran yang dapat digunakan guru dalam aktivitas membaca dan menulis, antara lain TAI (Team Assisted Individualization), STAD (Student Teams Achievment Division), Two Stay Two Stay, Jigsaw, Menulis 
Berputar (Write Around), TPS (Think Pairs Share), SQ3R (Survei, Question, Read, Recite, Review), dan Story Telling.

Terakhir, jika memungkinkan, sekolah juga dapat mempertimbangkan untuk membuat sistem literasi digital. Koleksi buku digital akan memberikan kemudahan bagi siswa untuk mengakses berbagai informasi di mana pun mereka berada. Hal ini dapat menjadi solusi yang inovatif dalam pembelajaran tatap muka terbatas saat ini agar siswa dapat mengakses informasi yang diperlukan dalam pembelajaran.

Keterlibatan berbagai pihak tentu diperlukan dalam mengaktualisasikan upaya-upaya yang telah diajabarkan di atas. Tidak hanya guru dan sekolah yang bertanggung jawab dalam mengemban amanah meningkatkan mutu generasi masa depan, tetapi juga dukungan dari orang tua, pemerintah, dan stakeholder ikut mempengaruhi hasil akhir dalam pembangunan kompetensi literasi pada siswa. Kontribusi dan keterlibatan dari berbagai pihak diharapkan akan meningkatkan kompetensi siswa saat pascapandemi.

\section{Daftar Pustaka}

Atmazaki. 2013. Implementasi Kurikulum 2013 Mata Pelajaran Bahasa Indonesia: Pola Pikir, Pendekatan Ilmiah, Teks (Genre), dan Penilaian Otentik. Proceeding of the 2nd ISLA 2013.

https://ejournal.unp.ac.id/index.php/isla/article/view/3 962

Fahmy, Zulfa. Dkk. 2021. Dampak Pandemi Covid-19 terhadap Minat Baca Siswa Sekolah Dasar. Jurnal Sastra Indonesia. 2021 Juli 26; 10(2): 121-126. DOI 10.15294/jsi.v10i2.48469

Hartyatni, Mijiatun Sri. 2018. Membangun Budaya Baca Melalui Pengelolaan Media Sudut Baca Kelas dengan "12345". 
Jurnal Pemikiran dan Pengembangan SD. 2018 April; 6(1):

1-11. DOI: https://doi.org/10.22219/jp2sd.v6i1.5906

Juminingsih. 2019. Membangun Budaya Literasi di Sekolah

Dasar Negeri Trangsan 02 Gatak Kabupaten Sukoharjo dalam Mendukung Keberhasilan Kegiatan Belajar Abad 21. Jurnal Pendidikan Ilmu Sosial. 2019 Juni; 29 (1): 56-64. DOI: 10.23917/jpis.v29i1.8255

Khair, Ummul. 2018. Pembelajaran Bahasa Indonesia dan Sastra (BASASTRA) di SD dan MI. Ar-Riayah: Jurnal Pendidikan Dasar. 2(1): 81-98. DOI: http://dx.doi.org/10.29240/jpd.v2i1.261

Sadli, Muhamad dan Saadati, Baiq Arnika. 2019. Analisis Pengembangan Budaya Literasi dalam Meningkatkan Minat Membaca Siswa di Sekolah Dasar. TERAMPIL: Jurnal Pendidikan dan Pembelajaran Dasar. 2019 Desember; 6 (2), 151-164.

DOI.

https://doi.org/10.24042/terampil.v6i2.4829

Subandiyah, Heny. 2015. Pembelajaran Literasi dalam Mata Pelajaran Bahasa Indonesia. Jurnal Pendidikan Bahasa dan Sastra Indonesia. 2015 Maret; 2(1): 12-16. DOI: https://doi.org/10.26740/parama.v2n1.p\%25p

Susanto, Heru. 2016. Membangun Budaya Literasi dalam Pembelajaran Bahasa Indonesia Menghadapi Era MEA. Jurnal Pendidikan Bahasa dan Sastra Indonesia. 2016 Maret; 1 (1): 12-16. DOI: http://dx.doi.org/10.26737/jp$\underline{\text { bsi.v1i1.70 }}$ 


\title{
KESIAPAN KEBERLANGSUNGAN PENDIDIKAN PASCA PANDEMI
}

\author{
Prof. Dr. Apridar, S.E., M. Si ${ }^{5}$ \\ Universitas Syiah Kuala (USK) Aceh
}

\begin{abstract}
"Kesiapan berlangsungnya pendidikan harus mampu dijadikan sebagai momentum agar mampu melahirkan berbagai inovasi terhadap lulusan yang dipersiapkan dengan baik oleh pendidika."
\end{abstract}

$\mathrm{H}^{\mathrm{i}}$ idup sukses dan sejahtera merupakan dambaan setiap manusia. Untuk memperoleh hal tersebut, maka sangat diperlukan teknologi yang bersumber dari ilmu pengetahuan. Sehingga pendidikan merupakan salah satu pintu yang membuka kearah kebajikan tersebut. Usaha

5Penuis lahir pada 13 April 1967 di Lhokseumawe, Aceh. Meraih gelar sarjana ekonomi (1993), gelar magister IESP serta gelar doctoral IESP dari Unsyiah. Rektor Unimal Periode (2010-2014 dan 2014-2018). Rektor Uniki Periode (2021-2025). Telah melahirkan 15 buah buku; Tsunami Aceh : Adzab atau Musibah, (2005), Ekonomi Moneter, (2008), Petunjuk Penulisan Karya Ilmiah, (2008), Ekonomi Internasional: Sejarah, Teori, Konsep dan Permasalahan Dalam Aplikasinya, (2009), Teori Ekonomi; Sejarah dan Perkembangannya, (2010), Ekonomi Kelautan dan Pesisir, (2011), Statistika Ekonomi , (2012), Daya Saing Ekspor Ikan Tuna Indonesia, (2014), Ekonomi Peradaban ; Ekonomi, Politik Pendididikan, dan Keagamaan, (2015), Ironi Negeri Sejuta Nyiur Hijau di Pantai; Pemberdayaan Nelayan dan Pembangunan Maritim di Indonesia, (2015), Menuju Kedaulatan Maritim Indonesia,(2016), Ekonomi Paska Perang, (2017), Ekonomi Internasional,"Sejarah, Teori, dan Permasalahan dalam Aplikasinya" Edisi 2, (2018), Konvergensi Pertumbuhan Ekonomi "Analisis Pascapelaksanaan Otonomi Daerah di Indonesia, (2019). Model Ekonomi Syariah; Fondasi Sistem Ekonomi (2020). 
sadar yang dilakukan secara terencana dalam mewujudkan suasana belajar dalam pendidikan, serta proses pembelajaran bagi peserta didik secara aktif dalam mengembangkan potensi diri merupakan tahapan dalam menapaki kehidupan yang lebih baik. Sehingga usaha agar memiliki kekuatan spiritual keagamaan, pengendalian diri, kepribadian, kecerdasan, akhlak mulia, serta keterampilan yang diperlukan dirinya dan masyarakat sangat penting dilakukan melalui pendidikan.

Arti sesungguhnya dari pendidikan adalah sebagai usaha sadar dan sistematis dalam mencapai kemajuan serta taraf hidup yang lebih baik. Pengertian pendidikan secara sederhana merupakan proses pembelajaran bagi peserta didik mampu memahami, mengerti, dan membuat manusia lebih kritis dalam berpikir. Sehingga dapat memahami kebenaran secara utuh dengan baik dan benar.

Sebagai mana ungkapan Ki Hajar Dewantara bahwa pendidikan merupakan tuntutan peserta didik terhadap kehidupannya. Sehingga maksud dari pendidikan yaitu sebagai penuntun dari berbagai kekuatan dan kodrat yang ada pada anak-anak, agar mereka sebagai manusia sekaligus anggota masyarakat untuk dapat mencapai keselamatan serta kebahagiaan yang lebih tinggi.

Suksesnya pendidikan akan diperoleh apabila orang tersebut mampu membentuk karakter dengan akhlak yang baik serta memiliki sikap santun dalam beriteraksi. Karakter yang merupakan sifat yang harus dimiliki bagi peserta didik dalam menggapai kelulusan. Dimana nilai-nilai pendidikan karakter yang bersumber dari agama harus menjadi peta jalan yang harus dimiliki setiap orang.

Pantulan dari karakter yang baik, secara alamiah akan terlihat pada nilai keimanan yang melekat pada diri 
seseorang serta akan terpancarkan pada nilai ketakwaan yang diperolehnya. Sikap religus akan terpancar pada diri seseorang denganadanya prilaku jujur, rendah hati serta jauh dari sikap sobong serta angkuh. Pembentukan diri yang santu dan bijaksana merupakan sikap mental yang akan memacu prilaku baik untuk berbuat berbagai kebajikan dalam mengarungi kehidupan yang lebih baik.

Karakter kinerja dan prilaku manusia yang baik akan terlihat dengan adanya sikap kerja keras dan ulet dalam melaksanakan berbagai tugas, serta tangguh yang diperlihatkan dengan tindakan yang tidak mudah menyerah. Motifasi positif ini merupakan salah satu karakter yang tertanam dalam jiwa peserta didik yang tentu jauh dari sifat cengeng. Setiap pekerjaan yang ditangani selalu di usahakan dengan optimal agar pekerjaan tersebut tuntas dikerjakan. Selesai dengan satu pekerjaan kemudian akan terus berusaha untuk membuka kesempatan pekerjaan berikunya yang juga diselesaikan dengan baik dan tuntas secara berkesinambungan.

Terhadap mereka yang sudah tertanam dalam dirinya karakter yang baik, tentu tidak paradok sebagaimana kerjanya jujur namun malas, atau kerjanya keras tetapi culas. Semua itu akan dilakukan dengan baik dan seimbang, dimana semua kerja dilakukan dengan baik dan benar. Motivasi positif demikian sangat perlu ditanamkan dalam model pembelajaran masadepan yang lebih baik. Tidaklah berlebihan, apabila barometer akhlak mereupakan nilai utama yang sangat di junjung tinggi.

Nilai-nilai yang harus ditanamkan dalam pendidikan modern kedepan yaitu sikap beranidan siap dalam berkompetisi dari berbagai arena yang ditekuninya. Dengan berfikir secara kritis, cenderung akan memiliki peluang 
yang besar untuk dapat memenangkan setiap kompetisi yang diikuti. Kalaupun terjadi kekalahan tidak dengan mudah menyerah. Namun akan selalu mencari alternatif jalan keluar dengan baik dan kreatif.

Kerja tim untuk berbagai pekerjaan skala besar membutuhkan pelatihan yang tepat dan hati-hati. Dengan cara ini, ketika pekerjaan lintas departemen dilakukan dalam skala besar, tidak akan ada hambatan untuk membangun "team work" yang andal untuk menyelesaikan setiap pekerjaan secara kolaboratif. Komunikasi yang baik antar tim sangat penting untuk berlatih dalam belajar yang lebih mandiri. Sehingga dalam hal membangun jaringan bukan lagi hal yang baru bagi setiap lulusan nantinya.

Untuk dapat memahami perkembangan zaman dan perubahan yang begitu cepat, sangat diperlukan penguasaan sifat-sifat yang baik. Di era digital seperti sekarang ini membaca, menulis, dan berhitung (kalistung) saja tidak cukup, tetapi ke depan harus dapat meningkatkan kemampuan daya baca, terutama untuk berbagai buku ilmiah dan informasi penting lainnya yang akan dijadikan pedoman kerja.

Apapun profesi yang digeluti, harus adanya kemampuan menguasai literasi budaya saat ini. Perilaku sehari-hari orang-orang di daerah tertentu dapat dibaca, sehingga dapat memahami berbagai peluang dalam produksi. Mekanisme kerjanya sama, tidak bertentangan dengan adat budaya yang dianut masyarakat. Jika kita tidak mampu menangkap literasi budaya, kemungkinan akan terjadi konflik dengan mekanisme kerja budaya lokal, yang akan berdampak fatal.

Terhadap literasi teknologi sekarang ini telah menjadi kinerja utama dalam setiap insan untuk membangun bangsa 
dan negara sangat diperlukan penguasaannya. Dengan penguasaan teknologi, diharapkan perkembangan pekerjaan untuk ditingkatkan akan semakin mudah adanya. Sehingga penguasan terhadap literasi teknologi sekarang ini sangat perlu dilaksanakan untuk berbagai bidang. Latihan serta penelitian dalam rangka peningkatan literasi teknologi perlu dilakukan secara mumpuni. Hal ini tentu akan dapat meningkatkan produktivitas dari lulusan.

Untuk lancarnya dalam menjalankan roda usaha yang akan dibangun kedepan, sangat diperlukan penguasan literasi keuangan yang tertip dan baik. Jika tidak dilakukan, kemungkinan akan terjerumus ke dalam penyalahgunaan dan pengelolaan keuangan, yang akan menjadi masalah yang fatal. Untuk itu, kemampuan menguasai literasi keuangan sangat diperlukan, dan diharapkan dunia usaha memiliki penilaian yang baik dan benar dari masyarakat.

Pencatatan keuangan yang teratur juga akan mempengaruhi efektifitas dan efisiensi penggunaan anggaran, sehingga mempengaruhi keuntungan yang diperoleh. Pembukuan yang bersih akan memberikan kesempatan yang lebih luas bagi semua pihak untuk berpartisipasi dalam investasi guna mencapai pengembangan usaha yang lebih baik di masa depan. Kinerja keuangan merupakan kinerja utama dari berjalan atau tidaknya suatu perusahaan. Hal ini juga berlaku untuk berbagai organisasi lain, seperti kelompok profesional dan sosial.

Dilihat dari berbagai kriteria yang telah disebutkan di atas, sudah tidak pantas lagi calon lulusan ditanya "mau jadi apa nanti". Namun dengan aturan ini, setiap lulusan harus bisa menjawab, "Apa yang akan saya lakukan di masa depan". Ia akan mampu merancang sebuah "business plan" 
dengan baik dan memastikan bahwa bisnis tersebut memiliki prospek yang luas dan dapat memperoleh keuntungan yang cukup besar.

Tindakan apa yang akan dilakukan selanjutnya untuk membuat kemajuan dan perkembangan di bidang usaha. Dengan ditampilkannya karya-karya cerdas, kita akan mampu meyakinkan semua pihak untuk berpartisipasi dan mewujudkan impiannya dalam karya nyata. Bimbingan dan bimbingan sangat diperlukan untuk menciptakan segala macam karya baik yang dapat membangun peradaban bangsa.

Konsep pembelajaran yang mampu mendorong serta melahirkan berbagai inovasi kreativitas sangat diperlukan bagi pendidikan masa depan bangsa. Ruang-ruang keluarga serta ruang kelas harus mampu dijadikan sebagai tempat untuk pengemblengan kebangkitan anak bangsa. Tantangan yang semakin komplek kedepan harus mampu dijadikan sebagai momentum agar mampu melahirkan berbagai inovasi terhadap lulusan yang dipersiapkan dengan baik oleh pendidikan moderen. Sehingga tidak ada lagi lulusan yang terbuai terlena dengan secuil prestasi masa lalu. Selesainya suatu pekerjaan, haru mampu menegerjakan pekerjaan yang telah menunggu untuk selanjutnya.

Moga keinginan untuk menoreh berbagai prestasi masa depan menjadi sasaran setiap lulusan. Sehingga tidak ada hari yang akan dilewati dengan tanpa adanya prestasi yang terukir. Rekam jejak yang ditinggalkan sebagai catatan amal, merupakan sejarah peradaban yang harus terus ditulis, agar mampu menyusun peta menuju keselamatan dunia dan akhirat. 


\title{
KUMPULAN PUISI BERHENTI DI KESUNYIAN SEBAGAI MEDIA PEMBELAJARAN APRESIASI SASTRA PASCAPANDEMI COVID I9
}

\author{
Gatot Sarmidi ${ }^{6}$ \\ Universitas PGRI Kanjuruhan Malang
}

“Guru bisa menggunakan model pembelajaran apresiasi sastra yang cocok untuk puisi berdasarkan bentuk, isi, dan fungsinya, dengan mendemonstrasikan atau memilih salah satu model pembelajaran dalam kegiatan apresiasi sastra."

\section{Pendahuluan}

W asa Pandemi Covid 19 menjadi masalah tersendiri 1 dalam dunia pendidikan, utamanya pembelajaran. Pascapandemi sebagai akibat dari terhentinya pembelajaran tatap muka di kelas, akhirnya perlu upaya keras untuk memulihkan keadaan dalam berbagai sektor termasuk pembelajaran apresiasi sastra. Sejumlah perbincangan akademik bidang pendidikan terbuka pada wacana revolusi

${ }^{6}$ Gatot Sarmidi lahir di Malang pada bulan Juli 1967. Sehari- hari bekerja sebagai dosen di Universitas PGRI Kanjuruhan Malang. Dalam bidang sastra ditekuni sejak SMA di Malang. Di dunia sastra, bergabung dalam Himpunan Sarjana Kesusastraan Indonesia (Hiski) dan Perkumpulan Cendekiawan Bahasa dan Sastra (Cebastra). Beberapa tulisan ada di beberapa jurnal ilmiah, juga esai sastra dan budaya dimuat di Nusa Daily, Kumpulan puisi yang sudah terbit Berhenti di Kesunyian (2021), dan Kumpulan Cerita Singkat Suryatriwung (2020), Kumpulan puisi Secawan Senja di Warung Kopi (2001), Kumpulan Cerita Pendek Bleng Blong Rembulan Malam (2001), dan Kumpuan Guritan Segara Langit (2001). 
4.0 dan society 5.0. Tak berbicara banyak dengan konsep itu, fokus pada bidang apresiasi puisi akan dicoba bersentuhan dengan pembelajaran apresisasi sastra yang menyadarkan siswa pada konsep masa depan berefleksi pada sebelumnya, yakni Pandemi Covid 19 dan pemikiran untuk melangkah di era berikutnya pascapandemi covid 19 . Sebuah tawaran dalam bidang sastra tentang kumpuan puisi Berhenti di Kesunyian sebagai hasil kreasi yang penulis gambarkan dalam mengisi waktu semasa pandemi Covid 19.

Berhenti di Kesunyian merupakan salah satu kumpulan puisi yang berbicara tentang ruang, waktu, hidup, dan lingkungan. Dalam kumpulan puisi ini sengaja disajikan dua macam puisi dalam bahasa Indonesia dan dalam bahasa Jawa. Kesengajaan itu untuk memperkenalkan bahwa penulis menghasilkan puisi dalam dua bahasa. Sebenarnya puisi-puisi dalam kumpulan puisi ini ditulis di masa pademi Covid 19. Tulisan-tulisan tersebut di antaranya memang bertautan dengan situasi di masa pademi. Tetapi tidak semuanya begitu. Penulis hanya menyajikan berkaitan dengan kehidupan sehari-hari yang mungkin biasa-biasa saja selama semuanya harus dikerjakan dari rumah.

Ruang waktu dan situasi sebagai bagian dari kehidupan yang dilatari desa. Beberapa hal memang muatan lokal walaupun belum tentu berisi nilai kearifan lokal. Tampaknya suasana di Malang Jawa Timur menjadi latar penting dalam penulisan puisi-puisi ini. Penulis sekadar menjadikan puisi sebagai ruang ekspresi begitu saja. Sebagaian memang agak menggurui. Itu karena tujuan penulis dalam menghasilkan karya seninya tidak terlalu murni. Posisi penulis sebagai seorang pengajar di perguruan tinggi memberikan kesan apa pun berkaitan dengan dunia pendidikan. Memang ada puisi yang direfleksikan melalui 
penelitian sederhana. Tetapi, itu tidak terlalu serius. Ada hal yang sederhana, karena sisi estetika juga kurang dipentingkan. Penulis lebih berorientasi pada fungsi puisi sebagai media pembelajaran. Harapan besar puisi-puisi dalam kumpulan puisi ini bisa bermanfaat, syukur diapresiasi manis.

\section{Hasil dan Pembahasan}

Puisi Berhenti di Kesunyian memberikan makna akan sebuah harapan ketika terlepas dari pandemi atau epidemi yang menyusahkan banyak orang. Pada sebuah malam yang tenang tidak terpikirkan seperti pada saat pandemi yang menggelisahkan perasaan. Malam hari yang tenang hanya suara serangga yang menghibur, bukan setiap saat menjadi bingung karena berita-berita yang simpang siur antara yang sebenarnya dan hoaks tentang pagebluk. Hari-hari yang biasa dan normal tak perlu masker dan handsanitaizer. Hari-hari yang biasa dalam keadaan normal, sikap dan menjalani hidup yang biasa dan selalu ingat tidak boleh takabur, tetap menjalani ibadah seperti dalam keadaan biasanya. Sebagai media apresiasi puisi, Berhenti di Kesunyian menjadi puisi utama yang ditulis penyair untuk membuka cakrawala peserta didik akan sebuah harapan baik, tetap sehat, selamat terhadap keadaan yang menurut Pemerintah dianggap sebagai bencana nasional di samping sebagai masalah global.

\section{BERHENTI DI KESUNYIAN}

Kubayangkan malam

Tanpa virus

Tanpa endemi atau pademik

Kubayangkan malam

Begitu tenang dan biasa 
Menyongsong PTMT Pada Dunia Pendidikan

Hanya suara serangga

Membuatku senang

Kubayangkan malam

Tanpa berita pagebluk

Berita buruk mencekam dunia

Kubayangkan kenyataan

Biasa saja tak bingung masker

Bingung sanitizer atau jejamu

Kenyataan itu biasa saja

Tanpa harus menghamba pada kecepatan

Biasa saja

Sehat dan selamat

Biasa saja

Sejahtera

Tanpa pengkhianat

Biasa saja

Berjalan apa adanya

Beribadah dan bersyukur

Biasa saja

Tanpa hati takabur dan tindakan

Ngawur

(Sarmidi, 2021:71)

Puisi berikutnya, puisi Lukisan Awan puisi yang digambarkan dari karya anak-anak yang menggambar awan. Lukisan itu dilukis di atas kanvas yang berwarna merah. Awan biasanya berwarna putih dilukis di kanvas merah. Awan yang dilukis menggambarkan keadaan pagi hari, warnanya putih tetapi tersinar matahari pagi seperti ungu dan jingga tergaris di langit yang cerah, pada lazuardi yang membuat perasaan senang. Pada siang hari awan itu putih dan bersih. Tetapi pada saatnya senja, awan berubah 
menjadi mendung. Suasana berubah menjadi suram, hitam kelabu menggantung di langit hingga gerimis turun menyejukkan rerumputan. Sebenarnya tidak hanya ruputrumput tetapi juga pepohonan dan perkampungan. Begitulah alam digambarkan penyair berserakan di langit, di dalam kanvas merah awan itu menyejukkan mata.

\section{LUKISAN AWAN}

Mungkin awan tak pernah tau ia adalah gambar yang terlukis di kanvas merah

Pagi terbayang sutra warna awan saputan lazuardi lukisan alam gempita

Suatu siang tak juga mengerti awan memutih pantulan surga

Mungkin tak tersadari awan senja muram tiba menggelatung lukisan jiwa ketika gerimis menyejukkan rumput rumput Awan berserak bagai saputan tangan memenuhi khayalan dan abstraksi lukisan mata

3012020

(Sarmidi,2021:23)

Penyair terlihat berseroloh, bergurau dalam puisi Lelucon Corona. Ia membuat plesetan kalau corona nama sebuah virus berasal dari kata coro yang dalam bahasa Jawa berarti kecoak dan kata na semacam akhiran saja. Kecoak itu berterbangan di dalam ruangan. Yang terbang tidak 
hanya kecoak tetapi juga kelelawar. Dalam ruangan itu, kecoak yang terbang banyak, lalu kelelawar yang juga terbang bertabrakan dengan kecoak-kecoak. Anak-anak menjerit dalam ruangan. Anak-anak ketakutan, risih, dan gelisah, serta ruangan menjadi gaduh. Kecoaknya semakin banyak dalam ruangan itu, anak-anak terganggu merasa jijik dan tidak menyenangkan. Dalam cerita ini, anak-anak menemukan solusi dengan mengambil sapu untuk mengusir kecoak dan kelelawar dalam ruangan. Tetapi perlu diingat, kecoak-kecoak itu mengeluarkan bau yang tidak enak yang membuat ruangan menjadi kacau. Anak-anak bekerja keras hingga kecapaian semua. Sungguh keadaan yang menyebalkan, tetapi menyenangkan juga. Perasaan mereka bercampur-campur digambarkan dalam puisi Lelucon Corona ini. Sebagai sebuah media pembelajaran yang bisa menumbuhkan sikap kritis dan solutif, puisi ini sebaiknya diajarkan dengan model pembelajaran Problem Based Learning.

\section{LELUCON CORO NA}

Coro ke sana kemari

Berterbangan berantakan

Bertabrakan seekor kelelawar

Masuk ruang remang

Kelelawar menjerit

Anak anak ketakutan

Coro semakin banyak

Na malam jadi olah raga

Membawa sapu lidi

Mengoyak nggoyak coro

Anak anak mengisak

Na loyo 
Coro coro semakin gentayangan

Menyebarkan bau tak enak

Sungguh menyebalkan

3012020

Coro=kecoak

(Sarmidi,2021:24)

Kegiatan apresiasi sastra di sekolah bukanlah hal yang baru dilakukan oleh guru dan siswa. Biasanya kegiatan itu diintegrasikan dalam konteks pembelajaran Bahasa Indonesia atau dintegrasikan dalam kegiatan literasi. Seperti contohnya, kegiatan apresiasi kumpulan puisi Berhenti di Kesunyian yang dihadirkan secara bersama-sama di SMPN2 Wagir Kabupaten Malang dalam kegiatan pembelajaran bersama guru, siswa, penyair, mahasiswa asistensi sekaligus peserta Kuliah Kerja Nyata Tematis di desa Gondowangi Kecamatan Wagir Kabupaten Malang. Kegiatan yang dikembangkan secara integratif, memanfaatkan puisi sebagai media pembelajaran yang mencerdaskan, kontekstual, sekaligus berfungsi untuk menumbuhkan karakter kreatif, mandiri, bekerja keras, bertanggung jawab, dan berpikir kritis. Hal itu relevan dengan kebutuhan abad keduapuluh satu dalam rangka mengondisikan siswa di masa pascapandemi dengan konsep $4 \mathrm{k}$, yaitu kritis berpikir, komunikasi, kolaborasi, dan kreatif solutif.

\section{Penutup}

Kumpulan Puisi Berhenti di Kesunyian merupakan buku yang diterbitkan oleh Penerbit Deepublish yang hadir berisi puisi-puisi yang ditulis oleh penyair di masa Pandemi Covid 19 sebagai sebuah gambaran keadaan yang kompleks keseharian di masa itu dengan multitematik. Beberapa 
contoh puisi diulas dalam artikel ini sebagai sebuah gambaran makna yang bisa dimanfaatkan dalam pembelajaran sastra di sekolah terutama berkaitan dengan kegiatan apresiasi puisi. Dalam kegiatan itu, pada dasarnya kumpulan puisi merupakan sarana literasi, tatapi juga bisa dimanfaatkan sebagai media pembelajaran yang digunakan untuk meningkatkan kompetensi siswa melalui kegiatan apresiasi sastra. Di sekolah, guru berperan penting dalam mengelola pembelajarannya secara efektif. Dalam hal ini, di sarankan guru bisa menggunakan model pembelajaran apresiasi sastra yang cocok untuk puisi berdasarkan bentuk, isi, dan fungsinya. Misalnya, dengan mendemonstrasikan atau memilih salah satu model pembelajaran dalam kegiatan apresiasi sastra yang dirancangnya.

\section{Daftar Pustaka}

Sarmidi, Gatot. 2021.Berhenti di Kesunyian.Yogyakarta: Penerbit Deepublish 


\title{
MODEL PEMBELAJARAN \\ KOLABORATIF PASCA PANDEMI
}

\author{
Sri Yulia Sari ${ }^{7}$ \\ UIN Sulthan Thaha Saifuddin Jambi
}

"Pembelajaran kolaborasi dapat meningkatkan motivasi belajar bagi siswa, karena mereka mendapatkan berbagai pengalaman yang membuat mereka terstimulan untuk belajar"

\section{Pendahuluan}

Teknologi Informasi berkembang dengan sangat maju 1 dan cepat. Covid 19 melumpuhkan hampir semua aspek kehdupan manusia, tidak terkecuali pada aspek pendidikan, yang terdampak cukup parah. Untuk memutus penyebaran virus corona, maka pemerintah menginstrukasikan untuk pembelajaran melalui sistem daring. Setelah kondisi pandemi covid 19 agak mereda, pemerintah mulai menerapkan pembelajaran dengan tatap muka terbatas, dimana pembelajaran tatap muka (luring) diselingi dengan pembelajaran daring. Pademi Covid 19 membuat situasi

\footnotetext{
${ }^{7}$ Penulis adalah dosen tetap Program Studi Pendidikan Guru Madrasah Ibtidaiyah (PGMI) Fakultas Tarbiyah dan Keguruan UIN Sulthan Thaha Saifuddin Jambi. Menyelesaikan pendidikan Strata I di Universitas Negeri Jambi pada Program Studi Pertanian, lulus tahun 2001. Melanjutkan jenjang pendidikan Strata II di UIN Sulthan Thaha Saifuddin Jambi pada Program Studi Manajemen Pendidikan Islam, lulus tahun 2004. Kemudian melanjutkan jenjang pendidikan strata III di Universitas Pakuan pada Program Studi Manajemen Pendidikan Islam, lulus tahun 2018.
} 
pembelajaran di rumah haruslah melaksankan model pembelajaran yang kolaboratif. Kegiatan kolaborasi memungkinkan manusia dengan manusia lainnya sebagai mahluk sosial untuk saling bekerjasama dan dan berkolaborasi. Dengan adanaya pandemi memaksa dunia pendidikan kita untuk menggunakan pembelajaran berbasis teknologi informasi dalam proses pembelajaran. Model pembelajaran yang berbasis teknologi informasi menunjukkan perkembangan yang luar biasa, karena hasil pencapaiannnya lebih pesat dibandingkan dengan sosialisasi yang telah dilakukan sebelumnya.

Implementasi model Pembelajaran kolaboratif memberikan banyak memberikan nilai tambah, baik bagi peserta didik maupun bagi guru. Nilai tambah tersebut antara lain; 1) peserta didik mendapatkan pengalaman bekerjasama bukan hanya dengan sesama teman sekelasnya, namun dengan siswa lain yang sebelumnya belum mereka kenal, 2) Interaksi antar peserta didik yang baru mereka kenal menjadi terarah karena mengikuti program yang sudah direncanakan oleh guru, 3) motivasi peserta didik menjadi meningkat dengan pembelajaran kolaboratif 4) Guru memberikan sumber belajar yang banyak kepada peserta didik. Selain itu dengan berbagi dan berkolaborasi, para pendidik pelakuk pendidikan bisa saling belajar, saling mengisi dan melengkapi, sehingga menghasilan sinergi dan energi yang positif.

\section{Pembelajaran Kolaboratif}

Kolaborasi adalah sifat yang menyiratkan bekerja dalam kelompok yang berisi dua atau lebih untuk mencapai tujuan bersama dan menghormati kontibusi masing-masing secara utuh. Model Pembelajaran kolaboratif adalah model pembelajaran yang menggunakan interaksi sosial sebagai 
sarana membangun pengetahuan. Kemunculan ide pembelajaran kolaboratif bermula dari perspektif filosofis terhadap konsep belajar. Untuk dapat belajar, seseorang harus memiliki pasangan. Peluang diterapkannya model pembelajaran kolaboratif saat ini tentu sangat terbuka luas. Jaringan Infrastruktur teknologi informatikasudah semikn maju. Teknologi sudah semakin cangih dibandingkan dengan dahulu.Kapabelilas guru-guru terhadap teknologi informasi juga semakin meningkat, sehingga guru-guru sudah mampu untuk menerpkan berbagai model pembelajaran yang inovatif. Dengan pembelajaran kolaboratif melibatkan peserta didik dan guru untuk saling bekerjasama dalam satu kelompok yang beragam tingkat kemampuannya untuk mencapai tujuan pembelajaran .

Model pembelajaran kolaborasi merupakan suatu hubungan antar peserta didik yang menumbuhkan sikap saling ketergantungan secara positif, menunjukkan sikap taggungjawab setiap individu, serta keterampilan komunikasi interpersonal. Model pembelajaran kolaboratif adalah bagian sebuah proses di mana peserta didik pada berbagai tingkat kemampuan (kinerja) bekerja sama dalam kelompok kecil menuju tujuan bersama. Ini adalah pembelajaran dengan pendekatan yang berpusat pada peserta didik yang berasal dari teori pembelajaran sosial serta perspektif sosio-konstruktivis tentang pembelajaran.

Model Pembelajaran kolaboratif merubah adanya proses pembelajaran yang tadinya hanya sharing informasi menjadi upaya mengkonsruks pengetahuan oleh peserta didik melalui belajar kelompok. Tugas yang ada dalam pembelajaran kolaboratif merupakan tugas miik bersama, bukan merupakan tugas individu. Fokus apada model pembelajaran kolaboratif pada kerjasama antar peserta 
didik untuk sharing informasi dan interkasi mengerjakan tugas yang telah diberikan. Tujuan utama penggunaan pembelajaran kolaboratif dalam proses pembelajaran

1. Memotivasi peserta didik agar dapat saling berkomunikasi, memberikan tangapan pada pertanyaan, dan mengemukakan pendapat yang berbeda serta memberi kesimpulan.

2. Peserta didik dituntut mempunyai tangungg jawab dan dapat memecahkan masalah bersama-sama dalam kelompok.

3. Peserta didik dapat saling sharing pendapat di kelas, karena materi pembelajaran yang banyak sehingga peserta didik aktif mengupas materi dan bertukar pendapat baik secara luring maupun daring sehingga dapat memperbanyak materi yang dimiliki siswa

4. Motivasi belajar peserta didik meningkat, karena mereka bekerja bersama-sama tidak secara individual. Membangun rasa percaya diri dan mandiri kepada peserta didik.

5. Memberi perasaan rileks kepada peseta didik dan pengalaman bekerja dalam kelompok bersama teman-teman.

Model pembelajaran kolaborasi setidaknya dafat dibagi menjadi tiga ranah, yakni; kolaborasi sebagai kompetensi, kolaborasi sebagai aksi atau implementasi, dan kolaborasi sebagai model pembelajaran.Selanjutnya kolaborasi sebagai Kompetensi ini sudah diadopsi pada Kurikulum pembelajaran 2013. Tidak hanya untuk peserta didik, kompetensi kolaborasi juga merupakan salah satu kompetensi bagi guru. Selanjuuntnya kolaborasi padaa 
ranah aksi atau implementasi, model kolaborasi merupakan suatu bentuk kerjasama untuk mencapai tujuan bersama.Pada ranah ini, impementasi bisa terjadi antar guru, antar sekolah, ataupun antar lembaga. Sedangkan kolaborasi model pembelajaran adalah upaya gurusebagai sebuah strategi pemecahan masalah pembelajaran dan mencapai tujuan pembelajaran secara optimal, melalui efektitivitas pembelajaran.

Terdapat banyak model-model Pembelajaran Kolaboratif, antara lain yang disebutkan oleh Suryani (2010), seperti: 1) Learning together, 2) Team Game Tournament, 3) Group Investigation, 4) Academic Constructive Controversy, 5) Jigsaw Prosedure, 6) Student Team Acheivment Division, 7) Complex Instruction, 8) Team Accelerated Instruction, 9) Cooperative Learning Structure, 10) Cooperative Integrated Reading and Composition. Suryani juga mengungkap sejumlah keunggulan dengan penerapan embelajaran kolaboratif, sebagai berikut; 1) prestasi belajar lebih tinggi; 2) pemahaman lebih mendalam; 3) belajar lebih menyenangkan; 4) mengembangkan keterampilan kepemimpinan; 5) meningkatkan sikap positif; 6) meningkatkan harga diri; 7) belajar secara inklusif; 8) merasa saling memiliki; dan 9) mengembangkan keterampilan masa depan

\section{Kesimpulan}

Model Pembelajaran kolaborasi adalah model pembelajaran yang efektif dalam pembelajaran pasca pandemi, karena model pembeajaran ini memungkinkan bagi guru dan peserta didik untuk melakukan kolaborasi lintas batas ruang kelas, batas geografis, dan bahkan batas negara.Pembelajaran kolaborasi juga dapat meningkatkan motivasi belajar bagi siswa, karena mereka mendapatkan 
Menyongsong PTMT Pada Dunia Pendidikan

berbagai pengalaman yang membuat mereka terstimulan untuk belajar. Guru juga dituntut menjadi lebih kreatif dan inovatif dengan penerapan pembelajaran kolaboratif ini. 


\section{STRATEGI DAKWAH DI MAJLIS TAKLIM PASCA PANDEMI}

\section{Siti Marlida, M.Ag8 \\ Universitas Muhammadiyah Bandung}

"Strategi dakwah dengan menetapkan sasaran dan tujuan yang hendak dicapai, dengan langkah analisis, mempertimbangkan kekuatan dan kelemahan, menyusun perencanaan, membangun komunikasi, dan evaluasi."

wal tahun 2020 masyarakat dunia di kejutkan oleh
virus Covid 19 yang menimbulkan pandemi dan menyebar ke seluruh belahan negara secara sporadis (secara tiba-tiba \& tidak merata). Dalam rentang waktu hampir dua tahun ini, pandemi Covid 19 telah menyebabkan banyak perubahan signifikan di seluruh aspek kehidupan. Dampak pandemi memaksa manusia untuk beradaptasi dengan situasi yang tak pernah dialami sebelum nya. terutama dalam pembatasan interaksi sosial seperti belajar, bekerja, beribadah,pernikahan dan lain sebagai nya. Semua aktifitas tersebut dialihkan pelaksanaan nya menggunakan teknologi melalui media virtual. Masyarakat juga harus merubah pola dan kebiasaan-kebiasaan yang

8Penulis lahir di Bekasi 17 Oktober 1970, penulis adalah dosen di Universitas Muhammadiyah Bandung dalam bidang ilmu Dakwah.Penulis menyelesaikan gelar Sarjana Bahasa Arab di Institut Agama Islam Negeri tahun 1995 sedangkan gelar Sajana Ilmu Dakwah di selesaikan di Universitas Islam Negeri Bandung tahun 2010. Selain mengajar, aktifitas penulis saat ini sebagai pengisi berbagai Majlis Taklim dan mengelola yayasan Pendidikan 
sudah biasa dijalani sebelum pandemi agar sistem kehidupan tetap terkendali.

Setiap perubahan dalam sistem kehidupan manusia pasti ada dampak positif maupun negatif nya. Demikian juga pandemi Covid 19 yang sekarang sedang dialami oleh masyarakat dunia menyisakan dampak negatif dan permasalahan yang harus di selesaikan dan dicarikan solusi nya. Di antara masalah yang harus difikirkan oleh masyarakat dan kaum muslimin adalah keberlangsungan aktifitas dakwah yang merupakan tanggung jawab bersama umat Islam.Aktifitas dakwah tidak boleh berhenti walau bagaimana pun berat nya problema yang dihadapi oleh manusia.Pandemi Covid 19 merupakan tantangan umat Islam dalam menyusun strategi menyampaikan ajaran Islam agar dakwah tetap bergulir sepanjang waktu dan di setiap tempat sehingga kebaikan ajaran Islam selalu dirasakan oleh seluruh manusia di bumi ini.

Kata dakwah selalu identik dengan aktifitas kaum muslimin menyeru manusia untuk melaksanakan ajaran Islam sebaik baik nya dalam kehidupan agar bisa meraih kebahagiaan di dunia dan di akhirat. Menurut Aminudin Dakwah adalah usaha yang dilakukan oleh seorang da'i untuk mengubah keadaan negatif yang terjadi pada orang atau sekelompok orang menjadi keadaan yang positif dengan memperjuangkan yang ma'ruf kemungkaran serta memenangkan hak atas kebatilan . Setiap muslim baik lakilaki maupun perempuan memiliki kewajiban yang sama dalam mengamalkan dan menyiarkan ajaran Islam di muka bumi ini.

Majlis taklim merupakan salah satu sarana dakwah dan menjadi ujung tombak dalam menyebarkan ajaran Islam kepada masyarakat.Peran majlis taklim sangat penting 
dalam mencerdaskan pemahaman dan pengamalan umat Islam melalui program pembinaan.pendidikan dan pemberdayaan umat secara intensif. Terlebih di masa pandemi ini saat masyarakat dihadapkan pada situasi sulit di seluruh aspek kehidupan yang sangat menggerogoti ketahanan iman dan kesehatan mental.Maka perlu sekali upaya pendampingan dan bimbingan spiritual kepada masyrakat oleh pemerintah, pemuka agama atau lembagalembaga dakwah khusus nya majlis taklim

Peran majlis taklim pasca pandemi seharus nya lebih dioptimalkan agar kaum muslimin tetap dapat menimba ilmu agama dan istiqomah mengamalkan ajaran Islam. Sebagaimana kita ketahui fungsi agama hadir dalam kehidupan manusia adalah untuk menjaga keseimbangan psikis manusia agar dapat menjalankan aktifitas hidup nya secara normal. Ideal nya penyampaian ajaran Islam dilaksanakan secara face to face agar da'i dapat berinteraksi langsung dengan para jamaah nya dan bisa mengamati langsung respon mad'u sebagaimana biasa nya yang sudah dilaksanakan sebelum Covid 19 merubah tatanan kehidupan Namun karena ada nya pembatasan sosial di masa pandemi ini ,maka aktifitas dakwah dalam kondisi darurat terpaksa dilakukan secara virtual dan para da'i sebagai komunikator dakwah harus pandai menyusun strategi dakwah dalam menyampaikan ajaran Islam sesuai dengan kapasitas keilmuwan, sumber daya yang dimiliki dan media teknologi yang sudah dikuasai .

Strategi dakwah merupakan kerangka bagi da'i dalam menyusun proses penyampaian ajaran Islam. Seorang da'i wajib menyusun strategi jika ingin dakwah nya berhasil mencapai sasaran. Menurut Wikipedia definisi Strategi yaitu pendekatan secara keseluruhan yang berkaitan dengan 
pelaksanaan gagasan, perencanaan, dan eksekusi sebuah aktivitas dalam kurun waktu tertentu. Sedangkan Menurut Craig dan Grant strategi yaitu penetapan tujuan dan sasaran dalam jangka panjang (Targeting and long-term goals). Strategi adalah perencanaan dalam menyusun sebuah tindakan atau kegiatan dengan menetapkan sasaran dan target yang hendak dicapai.

Henry Mintberg, James Brian Quinn, \& John Voyer mengartikan strategi dalam beberapa perspektif, pertama strategi sebagai perspektif memiliki arti bahwa strategi yang akan dibuat harus berdasarkan pada misi yang diemban oleh seseorang atau organisasi. Kedua strategi sebagai posisi, merupakan kemampuan dari seseorang atau organisasi dalam membentuk dan menempatkan beberapa orang ke dalam beberapa bidang pilihan agar keberadaan mereka dapat diingat oleh orang-orang yang berada di dalam atau di luar organisasi. Ketiga strategi sebagai perencanaan, merupakan proses penyusunan strategi yang dilakukan secara sistematik untuk mencapai tujuan yang akan datang dengan berlandaskan pada pertimbangan internal dan eksternal lingkungan organisasi. Keempat strategi sebagai pola kegiatan, yaitu strategi yang dibuat didalamnya berisi suatu pola atau desain terhadap penyelesaian masalah atau pekerjaan yang sedang atau akan dikerjakan. Kelima strategi sebagai rekayasa, strategi merupakan suatu seni untuk mengatur suatu kinerja agar apa yang dilakukan dapat secara berkesinambungan diukur keberhasilan pencapaian tujuannya Newman \& Logan menyatakan ada empat unsur dalam strategi yaitu:

1. Mengidentifikasi dan menetapkan spesifikasi dan kualifikasi hasil (out put) dan sasaran (target) yang harus dicapai, dengan 
mempertimbangkan aspirasi dan selera masyarakat yang memerlukan nya .

2. Mempertimbangkan dan memilih jalan pendekatan utama (basic way) yang paling efektif untuk mencapai sasaran.

3. Mempertimbangkan dan menetapkan langkahlangkah (steps) yang akan dtempuh sejak titik awal sampai dengan sasaran.

4. Mempertimbangkan dan menetapkan tolok ukur (criteria) dan patokan ukuran (standard) untuk mengukur dan menilai taraf keberhasilan (achievement) usaha.

Strategi dakwah merupakan aktifitas seorang da'i dalam merencanakan dan menyusun konsep dakwah dengan menetapkan sasaran dan tujuan yang hendak dicapai. Langkah-langkah da'i dalam merumuskan strategi dakwah pasca pandemic sebagai berikut ini :

1. Da'i melakukan suatu analisa yang mendalam dan akurat terhadap semua unsur dakwah dengan cara melakukan penilaian dari sisi kelebihan dan kekurangan penyusunan strategi dakwah yang sudah biasa dilaksanakan oleh da'i sebelum pandemi.

2. Da'i mempertimbangkan kekuatan dan kelemahan sumber daya da'i dari faktor eksternal dan internal nya serta mengamati faktor kondisi Mad'u atau jamaah majlis taklim

3. Da'i menyusun perencanaan dan strategi dakwah yang baru berdasarkan hasil analisis dan dan evaluasi kekuatan dan kelemahan da'i serta menentukan tema dan metode yang kira-kira 
dibutuhkan oleh jamaah.Da'i dalam menyampaikan dakwah nya tetap mengingatkan jamaah menerapkan protocol kesehatan dan menjaga jarak duduk selama menyimak dakwah.

4. Da'i membangun komunikasi dan kesepakatan dengan pengurus majlis taklim dalam menyusun \& memilih tema tema yang sesuai dengan kebutuhan jamaah majlis taklim. Terutama materi yang berkaitan dengan penguatan aqidah dan ahlak jamaah.

5. Da'i melakukan evaluasi setelah menyampaikan dakwah nya dan membuat perbandingan pencapaian dakwah nya sebelum dan pasca pandemi.

\section{Daftar Pustaka}

Abin Syamsuddin Makmun. 2003. Psikologi Pendidikan. Bandung: Rosda Karya Remaja.

Aminudin. 2016. Konsep Dasar Dakwah. Al-Munzir, 9(1), 2946.

Abdullah,2018,Ilmu Dakwah, Depok, PT Rajagrapindo Persada Ali Aziz,Moh, 2004,Ilmu Dakwah,Jakarta, Prenada

Munir, Muhammad, Ilaihi, Wahyu,2006, Manajemen Dakwah,Jakarta, Kencana Prenada Media Group

Suhandang,Kustandi,2015,Ilmu Dakwah, Bandung, PT Remaja Rosdakarya

Suparta, Munzier,Hefni,Harjani,2009,Metode

Dakwah,Jakarta,Kencana prenada Media Group

Tata Sukayat,Tata,2009,Quantum Dakwah, PT. Rhineka Cipta. 


\section{MENUMBUHKAN KEMANDIRIAN ANAK USIA DINI MELALUI METODE MONTESSORI PADA MASA PANDEMI COVID-I9}

\section{Selfi Lailiyatul Iftitah, M.Pd ${ }^{9}$}

IAIN Madura

"Metode Montessori membantu anak-anak untuk meniti jalan menuju kemandirian. Guru perlu membantu mereka berjalan, berlari, naik dan turun tangga tanpa bantuan, berpakaian sendiri, dan mengomunikasikan kebutuhan mereka dengan jelas"

$\mathrm{P}$ andemi COVID-19 telah membuat orang tua bertanyatanya bagaimana cara yang benar untuk merangsang anak-anak mereka bahkan ketika mereka di rumah. Selama pandemi covid-19, anak-anak cukup lama berdiam diri di rumah Akibatnya, secara fisik anak tidak bisa berinteraksi dengan teman. Terbatas atau tidak adanya kesempatan bermain di luar ruangan dan sosial juga dapat berdampak negatif pada anak-anak, membuat mereka cepat bosan, mudah tersinggung, dan putus asa (Kumar et al., 2020). Aktivitas yang dilakukan anak di rumah menjadi tantangan baru bagi orang tua. Padahal sebelum pandemi COVID-19,

9Penulis lahir di Pamekasan, 25 Mei 1992, penulis merupakan Dosen IAIN Madura dalam bidang Pendidikan Anak Usia Dini, penulis menyelesaikan gelar Sarjana Pendidikan Guru Pendidikan Anak Usia Dini di Universitas Negeri Surabaya (2014), sedangkan gelar Magister Pendidikan diselesaikan di Universitas Negeri Surabaya Program Studi Pendidikan Dasar Konsentrasi Pendidikan Anak Usia Dini (2016) 
anak-anak menghabiskan waktu pergi ke sekolah setiap pagi, belakangan ini anak-anak belajar dan tinggal di rumah.

Persoalan yang dihadapi oleh orang tua adalah belajar bersama anaknya di rumah dengan pembelajaran online ini, yang mengharuskan anaknya untuk mandiri menyelesaikan semua kegiatan belajar sekolah di rumah. Selain itu, Orang tua harus merangsang perkembangan anaknya di rumah. Keragu-raguan orang tua juga berdampak. Setiap permintaan anaknya cenderung dituruti oleh orang tua saat di rumah. Tidak mematuhi kemauan anak-anak, menyebabkan kemandiriannya tidak dirangsang dengan baik. Tentu saja, hal di atas menimbulkan banyak masalah, terutama dalam perkembangan anak.

Anak usia dini merupakan usia emas. Pada usia inilah anak akan sangat mudah menangkap informasi dari berbagai sumber. Oleh karena itu, usia dini merupakan kesempatan yang sangat berharga yang tidak boleh terabaikan karena usia dini tidak akan terulang kedua kali. Selain itu, masa emas adalah masa anak usia dini untuk mengeksplorasi hal-hal yang ingin mereka lakukan, masa golden age merupakan masa yang paling penting untuk membentuk karakter anak. membentuk karakter anak adalah tanggung jawab orang tua karena anak terlahir dalam keadaan suci, orang tualah yang akan menjadikan anak tersebut seperti apa.

Berdasarkan hasil penelitian, bahwa usia dini merupakan usia yang sangat penting bagi perkembangan anak yang berkesinambungan. Pada usia 0-4 tahun perkembangan kecerdasan anak mencapai 50\%, pada usia 4-8 tahun berarti perkembangan kecerdasan anak mencapai 30\% dan pada usia 8-18 tahun perkembangan kecerdasan anak 20\% (Kertamuda, 2015:2). Dengan demikian, masa 
keemasan dimulai pada masa kanak-kanak, di mana orang tua harus merangsang perkembangan intelektual anakanaknya agar dapat membentuk karakter baik. Namun, karakter baik tidak akan terbentuk secara optimal jika tidak dirangsang pada masa usia dini. Karakter yang dikembangkan pada anak usia dini adalah Mandiri.

Dalam kehidupan, manusia membutuhkan keterampilan yang dapat digunakan untuk memecahkan berbagai masalah yang dihadapinya agar dapat bertahan hidup. Keterampilan bertahan hidup ini dikenal sebagai kecakapan hidup. Salah satu kecakapan hidup diantaranya adalah kemandirian

Kemandirian merupakan kombinasi dari beberapa kecakapan hidup yang harus diajarkan sejak kecil dan bertahap seiring dengan bertambahnya usia dan kemampuan anak. Kemandirian adalah suatu keadaan dimana anak mau menolong dirinya sendiri tanpa bantuan orang dewasa di sekitarnya Lie dan Prasanti (2004:2) menyatakan bahwa kemandirian adalah kemampuan untuk melakukan kegiatan atau tugas sehari-hari sendiri atau dengan sedikit bimbingan sesuai dengan tahapan perkembangan dan kapasitasnya (Rianawati, 2014).

Kemandirian melakukan aktivitas sehari-hari akan memberikan suntikan percaya diri pada anak, ia akan merasa bisa melakukan hal-hal yang baru tanpa canggung karena pengalaman menyelesaikan tugas aktivitas kemandirian sebelumnya. Akumulasi dari rasa percaya diri anak yang tumbuh karena aktivitas kemandirian akan mengokohkan jiwa dan pikirannya. Sekaligus sebagai stimulasi optimal tumbuh kembang anak. Anak pada awalnya memiliki ketergantungan besar pada orang tua sebab mereka belum memiliki kemampuan yang baik untuk 
menyelesaikan pekerjaan mereka sendiri. Namun, ketergantungan tersebut, perlahan akan terkikis dengan usia yang bertambah dan kemampuan motorik kasar dan halus yang sudah berkembang. Sejalan dengan hal itu, orang tua harus mendorong anak-anaknya untuk mandiri

Kemandirian dalam bentuk yang paling kita kenal meliputi kegiatan sehari-hari untuk membantu diri kita sendiri. Misalnya mandi sendiri, makan sendiri, memakai dan melepaskan pakaian sendiri dan sebagainya. Kemandirian berkaitan erat dengan kemampuan memecahkan masalah yang terdiri dari mengatasi masalah sehari-hari dan ingin melakukan sesuatu tanpa bantuan orang lain. Maka tak heran jika kemandirian akan berdampak positif bagi anak. Ini akan menjadi orientasi dalam hidupnya karena ia harus berinteraksi dengan orang lain dan berpartisipasi dalam masyarakat.

Ketika anak-anak diajarkan kemandirian secara bertahap sejak dini maka mereka tidak akan pernah merasa sulit untuk menguasai kemandirian.Tujuannya tidak hanya membuat anak bisa mandiri akan tetapi agar anak mau mandiri. Kemandirian pada anak akan bermanfaat untuk membentuk pikiran yang mandiri. Hal ini karena ketika menjadi dewasa, anak harus dapat mengambil keputusan dan tindakan melalui hasil analisis dan pemikiran, usaha sendiri, dan siap untuk bertanggung jawab atas konsekuensi dari keputusannya.

Maria Montessori adalah sosok yang sangat terkenal di lingkungan pengasuhan anak dan dia juga dikenal sebagai seorang filsuf tentang pengasuhan anak. Ketika menyebut nama Montessori, orang akan langsung mengingat Taman Kanak-Kanak.Montessori adalah seorang dokter wanita Italia pertama. Ia lahir di Chiaravalle, sebuah provinsi kecil 
di Ancona, Italia. Pada 1870 Reputasinya di bidang pendidikan anak dimulai setelah Montessori lulus dari sekolah kedokteran (Lesley, 2017).

Menurut Savitri (2019:34-37), Salah satu prinsip pendekatan Montessori yang berkaitan dengan kemandirian anak adalah membentuk pribadi yang mandiri, percaya diri dan menghargai perbedaan. Dalam hal kemandirian seorang individu, Montessori percaya bahwa sebelum seseorang dapat membantu orang lain, dia harus menolong dirinya sendiri terlebih dahulu. Untuk keperluan itulah maka latihan untuk menjadi mandiri. Dalam hal apapun supaya mampu menolong dan memenuhi kebutuhan dirinya sendiri sangat penting untuk dimulai sejak usia dini. Meskipun harus melihat anak-anak ini berupaya keras menyelesaikan masalah serta beberapa kesulitan, tahanlah sebentar untuk tidak banyak membantu. Bukan berarti kita tidak berempati kepada anak. Bukan juga sadis karena tidak mau membantu namun sebaliknya itu berarti kita membantu mereka lebih banyak lagi, bukan sekedar hasil yang kita apresiasi justru jerih payahnya yang mau kita angkat tinggi-tinggi, Tujuannya agar anak tidak merasa bosan dan cepat menyerah untuk mencoba lagi dengan usahanya sendiri meskipun hasilnya jauh dari dari yang diharapkan. Memang susah menahan dari harapan. Memang sudah menahan diri untuk tidak membantu, tetapi jika kita melakukannya berarti kita memberikan kepercayaan kepada mereka. Berikan komentar positif terhadap proses dan kegiatannya dalam menyelesaikan masalah. "Please help me to do it by my self. Ketika anak sanggup menyelesaikan sendiri masalahnya, walau masalah tersebut sering kali tampak sepele di mata orang dewasa. Sebenarnya efek yang didapat untuk membangun kepercayaan diri nya besar sekali. Jika 
kepercayaan diri sudah ada, rasa berharga diri pun akan tumbuh. Seseorang yang merasa nyaman karena dihargai oleh sekelilingnya akan menjadi modal baginya untuk kelak dia akan berlaku sama pada kehidupan sosialnya individu yang dihargai akan menjadi individu yang menghargai. Jadi ketika anak-anak melakukan sesuatu, biarkan mereka melakukannya sendiri meskipun mereka kesulitan memecahkan masalah yang mereka hadapi

Menurut Montessori, peran orang dewasa adalah membantu anak-anak untuk meniti jalan menuju kemandirian (Lesley, 2017). Kita perlu membantu mereka berjalan, berlari, naik dan turun tangga tanpa bantuan, berpakaian sendiri, dan mengomunikasikan kebutuhan mereka dengan jelas. Hal ini dapat memberikan rasa puas pada anak ketika suatu tujuan tercapai.

Di tengah pandemi COVID-19, benar-benar membawa tantangan baru bagi para orang tua dalam memberikan kegiatan yang menyenangkan dan tidak membosankan bagi anak-anaknya. orang tua dituntut untuk menjadi pendidik anak. Dukungan yang diberikan oleh orang tua untuk memastikan bahwa anak-anak mereka menerima stimulasi yang memadai memainkan peran penting dalam mengembangkan kemandirian anak-anak mereka selama pandemi COVID-19 melalui aktivitas sehari-hari yang biasa dilakukan anak di rumah misalnya mandi, berpakaian. Kegiatan ini telah menjadi stimulus yang baik untuk mengembangkan kemandirian anak. Guru dan orang tua berpartisipasi dalam pengembangan kemandirian anak dengan memberikan pekerjaan rumah untuk merangsang perkembangan kemandirian pada anak 


\section{Daftar Pustaka}

Britton, Lesley. 2017. Montessori Play and Learn. Yogyakarta:PT Bentang Pustaka.

Danauwiyah, Nur Mauliddah, Dimyati. 2022. Kemandirian Anak Usia Dini di Masa Pandemi Covid-19. Jurnal Obsesi:Jurnal Pendidikan Anak Usia Dini Volume 6 Issue 2:588-599. Doi:10.31004/obsesi .v6i2.994

Kertamuda, Miftachul Achyar. 2015. Golden Age. Jakarta: PT Elex Media Komputindo

Kumar, A., Nayar, K. R., \& Bhat, L. D. 2020. Debate: COVID-19 and children in India. Child and Adolescent Mental Health. https://doi.org/10.1111/camh.12398

Rianawati. 2014. Implementasi Nilai-nilai Karakter pada Mata Pelajaran Pendidikan

Savitri, Iva Maya. 2019. Montessori for multiple intelligences. Yogyakarta:Bentang Pustaka. 
Menyongsong PTMT Pada Dunia Pendidikan 


\title{
UPAYA MENCINTAI KULINER FLORES MELALUI MATA KULIAH PENDIDIKAN BUDAYA LOKAL
}

\author{
Maria Marietta Bali Larasati, M. Hum ${ }^{10}$ \\ PBSI FKIP Universitas Flores
}

\begin{abstract}
“Memprogram mata kuliah Pendidikan Budaya Lokal untuk melakukan praktikum membuat kuliner tradisional Flores dengan tujuan agar memiliki sikap menghargai dan mencintai kekhasan kuliner tradisional Flores."
\end{abstract}

$\mathbf{B}_{\text {tradisional yang terdapat di seluruh wilayah kepulauan }}^{\text {udaya dan tradisi Indonesia dapat dilihat pada kuliner }}$ Nusantara sebagai salah satu warisan leluhur yang perlu dilestarikan. Kuliner tradisioal Indonesia adalah semua jenis kuliner yang berasal dari berbagai daerah di wilayah Negara Kesatuan Republik Indonesia. Bahan-bahan dan cara pengolahan kuliner tradisional bersifat alamiah dan diwariskan secara turun temurun. Cita rasa yang khas dari kuliner tradisional berbeda antara satu daerah dengan daerahnya lainnya. Hal ini yang menyebabkan terdapat berbagai variasi kuliner tradisional dengan keunikan dan kaya aneka rasa

10Penulis lahir di Denpasar, 07 Maret 1970. Penulis adalah dosen di Program Studi Pendidikan Bahasa dan Sastra Indonesia, Fakultas Keguruan dan Ilmu Pendidikan, Universitas Flores. Penulis menyelesaikan gelar Sarjana Pendidikan di IKIP Negeri Malang (1992) dan gelar Magister Humaniora di Universitas Udayana Denpasar (2009). Saat ini penulis menjadi Ketua Asosiasi Tradisi Lisan Flores di Ende. 
(https://id.wikipedia.org/wiki/Kuliner tradisional indones ia).

Menurut Guerrero (dalam Tyas 2017:3), makanan tradisional atau kuliner lokal adalah hasil olahan makanan yang biasa dikonsumsi oleh suatu komunitas etnik tertentu atau disajikan dalam ritual adat dan waktu tertentu, diwariskan secara turun temurun dibuat tetap atau dengan sedikit modifikasi, dan memiliki ciri khas tertentu sehingga berbeda dengan kuliner tradisional daerah lain.

Hasil survey psikografis Loewe pada tahun 2010 di Indonesia menyatakan bahwa makanan tradisional hanya menyentuh angka 20,1\% dari masyarakat konsumen Indonesia. Masyarakat konsumen ini adalah yang menetap di desa, tidak punya banyak kebutuhan, hidup sederhana, dan tingkat sosial ekonomi rendah. Agar dapat diminati kelompok konsumen mapan, percaya diri dan berkarakter kuat serta kelompok konsumen realistis yang merupakan 28,7\% dari seluruh masyarakat konsumen Indonesia harus dilakukan upaya maksimal (Gardjito, 2013).

Ada sebagian kuliner tradisional Indonesia yang sudah dikenal banyak orang dan ada yang belum dikenal soal kenikmatan dan kandungan kulinernya. Kurangnya pengenalan dan apresiasi terhadap tradisi dan sejarah kebudayaan kuliner tradisional juga menjadi faktor utama. Salah satu kuliner yang belum banyak dikenal orang adalah kuliner tradisional Flores. Kuliner tradisional Flores merupakan salah warisan budaya yang harus digiatkan kembali sebagai salah satu kekayaan budaya melalui cara atau perbuatan untuk menghidupkan kembali lewat berbagai program kegiatan. Hal ini perlu dilakukan untuk mengantisipasi masuknya kuliner asing sebagai efek pasar bebas dan globalisasi. Pada era digital sekarang ini, kuliner 
tradisional akan semakin tidak dikenal dan kalah dengan pengaruh makanan cepat saji yang berasal dari negara lain. Mahasiswa yang mengikuti perkembangan kuliner lewat tren digital beranggapan kuliner tradisional Flores adalah makanan yang kuno dan lebih memilih kuliner dari negara lain yang dianggap lebih modern.

Pada masa ini, perkembangan zaman dan perilaku generasi muda yang semakin modern mendorong minat generasi muda untuk lebih memilih menikmati makanan barat dibandingkan kuliner tradisional sehingga menyebabkan makanan tradisional semakin tergusur (Sulistiyo, 2019:62).

Mahasiswa semester tiga Program Studi Pendidikan Bahasa dan Sastra Indonesia, Universitas Flores sebagai bagian dari masyarakat Flores pada umumnya mengalami dilemma antara kuliner tradisional Flores dan kuliner dari negara lain yang menurut mereka lebih keren dari sisi penyajian dan rasa, seperti: pizza, nugget, kimchi, tteokbokki, dan bulgogi. Pergaulan, kecanggihan teknologi, serta perkembangan industri kuliner menjadikan banyak mahasiswa Program Studi Pendidikan Bahasa dan Sastra Indonesia, Universitas Flores kurang mengenal berbagai kuliner tradisional Flores.

Oleh karena itu, diperlukan berbagai upaya dari seluruh pihak untuk terus menjaga eksistensi kuliner tradisional tersebut. Salah satu upaya yang telah dilakukan adalah dengan menjadikan kuliner tradisional Flores sebagai salah satu obyek pada kegiatan praktikum mata kuliah Pendidikan Budaya Lokal.

Mahasiswa semester tiga program studi Pendidikan Bahasa dan Sastra Indonesia, Fakultas Keguruan dan Ilmu Pendidikan, Universitas Flores telah melakukan pratikum 
beberapa kuliner tradisional Flores sebagai bagian dari mata kuliah Pendidikan Budaya Lokal. Beberapa kuliner tradisional Flores tersebut adalah lekun (Maumere), filu (Lio), rebok (Manggarai), alu ndende (Ende).

\section{Lekun}

Lekun adalah salah satu kuliner tradisional dari daerah Sikka, Flores, NTT. Lekun dibuat dari bahan utama tepung beras ketan hitam, yang dicampur dengan kelapa parut, larutan air gula, dan buah pisang yang sudah masak. Cara pembuatannya cukup unik karena menggunakan bambu. Semua bahan yang telah dicampur tadi dimasukkan ke dalam bambu kemudian dibakar di atas api sampai masak. Lekun biasanya disajikan pada ritual-ritual adat.

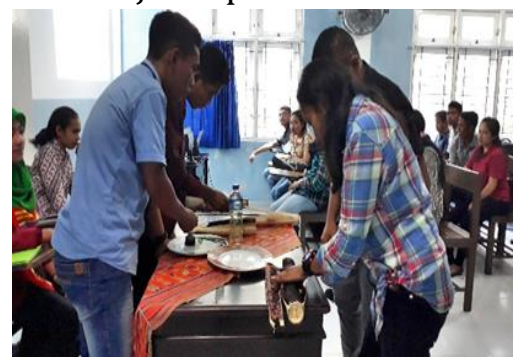

2. Filu

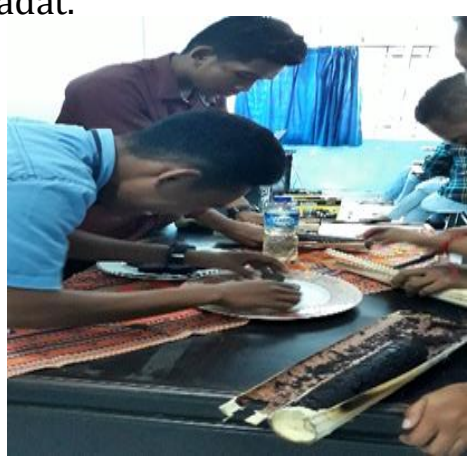

Filu adalah salah satu kuliner tradisonal dari daerah Lio, Flores, NTT. Bahan-bahan yang diperlukan untuk pembuatannya adalah tepung beras, gula pasir atau gula merah, sedikit arak dan minyak goreng. Cara membuatnya gula merah, air, dan daun pandan dimasukkan dalam panci, lalu aduk bahan-bahan tersebut sehingga merata dan gula larut. Kemudian, saring dan sisihkan. Masukkan tepung terigu, garam, dan tepung beras ke dalam wadah. Aduk adonan hingga 
tercampur rata, lalu masukan air rebusan daun pandan sedikit demi sedikit. Aduk lagi hingga adonan merata. Ambil adonan menggunakan sendok sayur dan masukan ke dalam majan dengan minyak yang sudah panas. Putar-putar adonan menggunakan lidi hingga matang dan siram bagian atas kue cucur menggunakan minyak. Kue cucur pandan siap untuk dinikmati. Filu biasanya disajikan pada saat upacara adat, namun sekarang sudah dibuat untuk teman minum sore.

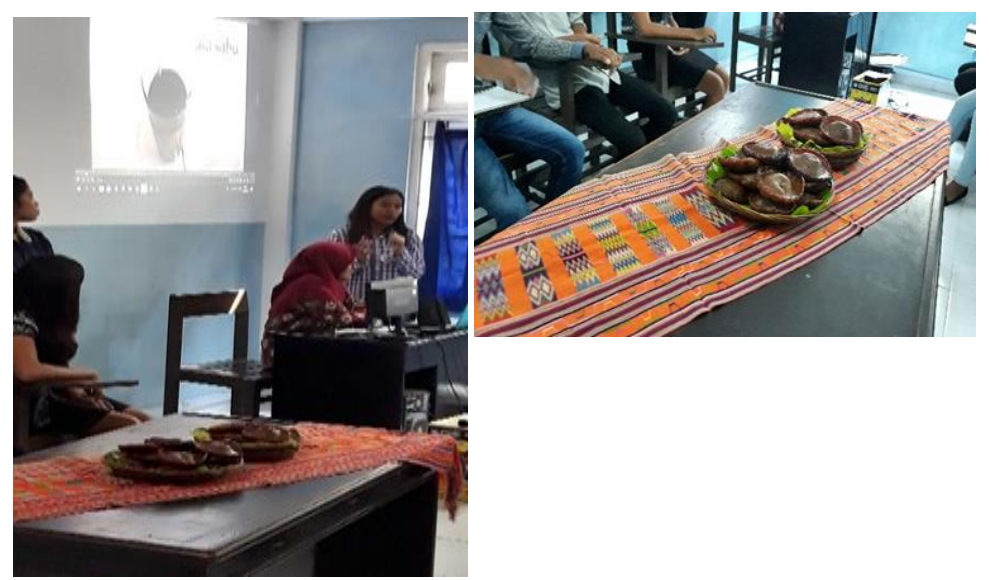

\section{Rebok}

Rebok salah satu kuliner tradisional dari daerah Manggarai, Flores, NTT. Rebok terbuat dari bahan dasar beras dan jagung yang dicampur kelapa parut, telur, vanili, dan gula. Cara membuat rebok adalah memasukkan tepung beras, kelapa parut, telur, dan vanili ke dalam wadah. Aduk-aduk hingga merata, setelah itu remas-remas adonan hingga kalis dan tidak lengket sampai menyerupai butiran-butiran kecil. Siapkan wajan tanpa diolesi minyak, sangria adonan hingga berwarna kecoklatan. Tambahkan gula pasir sesuai selera. 

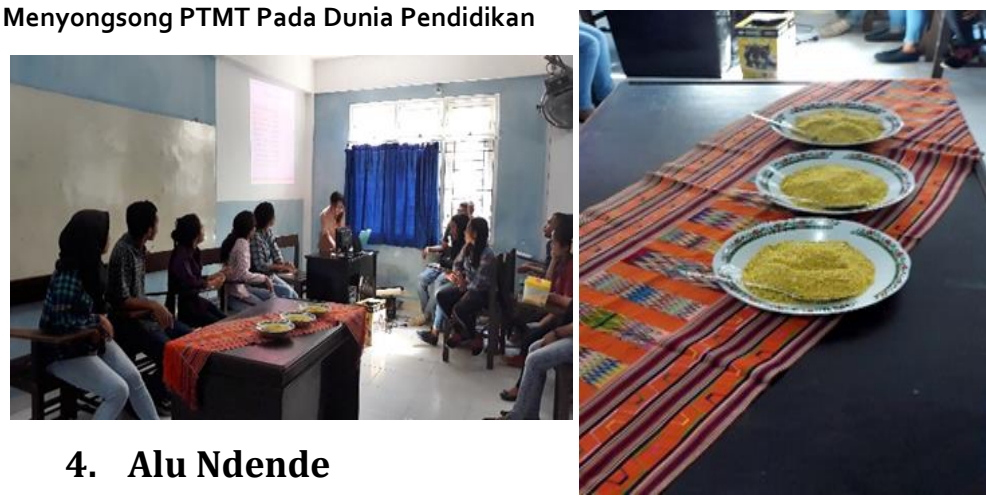

4. Alu Ndende

Alu Ndene merupakan kuliner tradisional orang Ende Flores, NTT. Alu Ndende biasanya disebut pizzanya orang Ende. Makanan ini terbuat dari air singkong yang dikumpulkan dan disimpan. Setelah diendapkan, bagian atas air jernih dibuang, kemudian pati atau endapannya digunakan sebagai bahan utama pembuatan alu. Endapan ini sebelumnya dijemur untuk membuat tepung ubi jalar tapioka. Tepung ini kemudian dicampur dengan air atau santan menjadi adonan, kemudian langsung dipanggang di penggorengan.

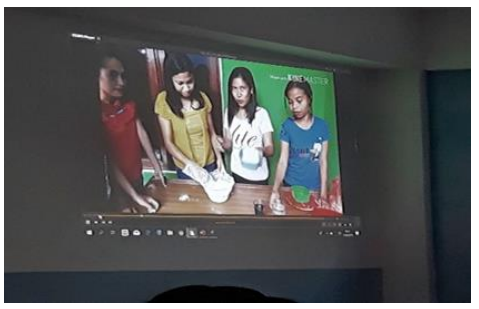

Salah satu cara

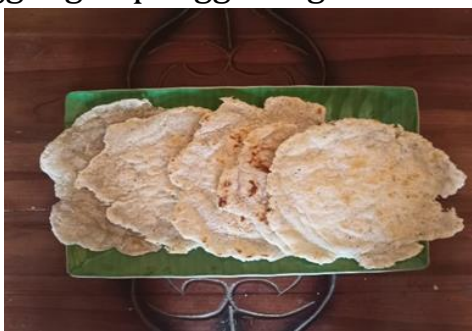

mengangkat keberadaan kebudayaan daerah adalah dengan menggali keanekaragaman kuliner tradisional daerahnya. Kuliner tradisonal harus dilestarikan dan dikenalkan pada seluruh masyarakat Indonesia bahkan harus dikenal juga di luar negeri. Jika generasi muda khususnya mahasiswa lebih menyukai makan dari barat, hal 
tersebut akan membuka peluang kuliner tradisional akan punah.

Salah satu upaya agar mahasiswa dapat mencintai kuliner tradisional Flores adalah mahasiswa semester tiga program studi Pendidikan Bahasa dan Sastra Indonesia, Fakultas Keguruan dan Ilmu Pendidikan, Universitas Flores yang memprogram mata kuliah Pendidikan Budaya Lokal harus melakukan praktikum membuat kuliner tradisional Flores. Hasilnya menujukkan adanya sikap menghargai dan mencintai kekhasan kuliner tradisional Flores.

\section{Daftar Pustaka}

Tyas, Agnes Siwi Purwaning. 2017. "Identifikasi Kuliner Lokal Indonesia dalam Pembelajaran Bahasa Inggris". Jurnal Pariwisata Terapan. No. 1. Vol. 1. Hlm. 1-14. https://jurnal.ugm.ac.id/jpt/article/download/24970/16 $\underline{061}$

Gardjito, Murdijati, dkk. 2013. Pangan Nusantara Karakteristik dan Prospek untuk Percepatan Diversifikasi Pangan. Jakarta: Kencana Prenada Media Group.

Wikepedia. Kuliner Tradisional Indonesia. 2021. https://id.wikipedia.org/wiki/Kuliner tradisional indone sia

Sulistiyo, Tri Djoko dan Christoforus Kevin. 2019. "Pengaruh Brand Image dan Packaging Getuk Singkong Terhadap Minat Generasi Muda Mengkonsumsi Makanan Tradisional Di Jabodetabek". Journal FAME. Vol.2. No.2. Hlm. 61-71. https://journal.ubm.ac.id/index.php/journalfame/article/view/1988 
Menyongsong PTMT Pada Dunia Pendidikan 


\section{BAB II \\ ILMU EKONOMI \\ PASCAPANDEMI}

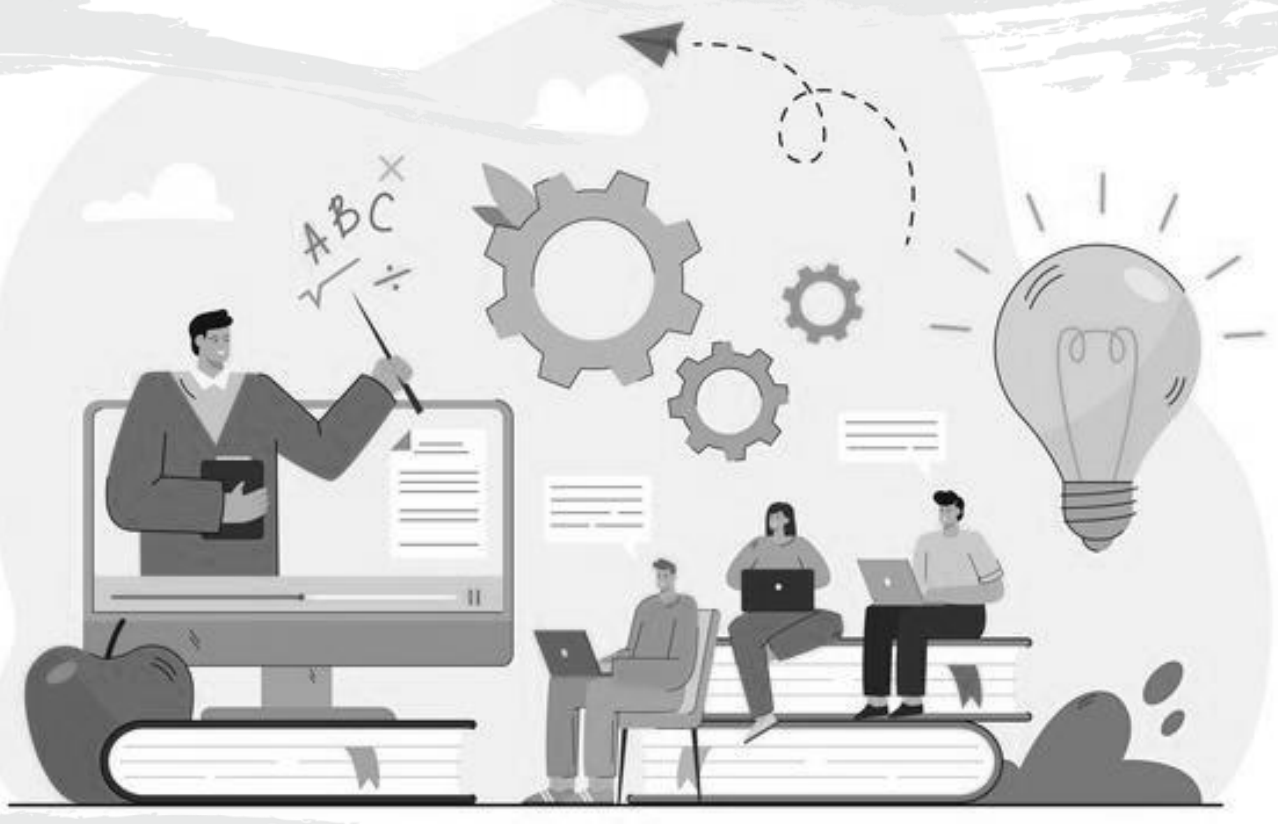


Menyongsong PTMT Pada Dunia Pendidikan 


\title{
STRATEGI PEMULIHAN PARIWISATA \\ PASCA PANDEMI
}

\author{
Dr. Syarifuddin, M.Pd. ${ }^{11}$ \\ Universitas Sriwijaya
}

"Keterlibatan dan kedisiplinan manajemen, staf dan tamu dalam mengikuti protokol kesehatan ini sangat penting untuk merevitalisasi industri pariwisata dan menghindari virus corona"

Dandemi COVID-19 telah mempengaruhi berbagai bidang kehidupan manusia. Industri pariwisata yang diharapkan menjadi sumber devisa terbesar kedua Indonesia, mengalami penurunan tajam. Beberapa langkah stimulus yang disiapkan pemerintah untuk menghidupkan kembali industri pariwisata ternyata belum mampu mencegah dampak negatif COVID 19. Minimnya wisatawan domestik dan mancanegara mengakibatkan penutupan banyak atraksi budaya dan penurunan sebagian besar hotel, yang berarti tidak ada pendapatan bagi mereka yang bergerak di bidang pariwisata dan pengumpulan pendapatan. kepada pemerintah provinsi (Solemede Ivan, 2020).

Menurut WHO, pandemi adalah penyebaran penyakit baru yang meluas. Sementara itu, menurut Inspektur Jenderal Kementerian Pendidikan dan Kebudayaan,

11Penulis karya ini ini ialah Syarifuddin, merupakan dosen di Universitas Sriwijaya. 
pandemi adalah epidemi yang menyebar di seluruh dunia, mencakup wilayah geografis yang luas. Pandemi adalah epidemi yang menyebar di hampir seluruh negara atau benua, sering kali mempengaruhi banyak orang. Berdasarkan dua definisi pandemi di atas, dapat disimpulkan bahwa pandemi adalah penyebaran penyakit baru ke seluruh dunia. Pada 11 Maret 2020, WHO menyatakan COVID19 sebagai pandemi. Pada 1 Maret 2020, Indonesia menyatakan COVID19 sebagai bencana nasional (WHO. 2020).

Pariwisata sudah menjadi bagian yang tidak dapat dipisahkan dari kehidupan sehari-hari di masyarakat. Karena aktivitas wisata yang sebelumya hanya dapat dinikmati oleh beberapa orang saja sekarang aktivitas wisata dapat dinikmati oleh masyarakat besar maupun kecil yang ada di dunia ini. Berwisata kini sudah menjadi kebutuhan. Bermacam hal kegiatan untuk dapat melakukan wisata yaitu dapat menghilankan kebosanan dikarenakan kegiatan yang berlebihan, perembangan arus globalisasi yang dapat memudahkan teknologi pada saat ini sehingga dapat memudahkan masyarakat memperoleh pengetahuan dan informasi mengenai kemajuan pariwisata saat ini, meningkatkan keberanian seseorang untuk mengakses dan membagikan berbagai foto berserta dokumen di media sosialnya serta ada beberapa sebab yang lainnya (Sutrisnawati, 2020).

Pariwisata merupakan suatu perjalanan ke tempat lain yang tidak menetap dan sementara, yang biasanya dilakukan oleh sendiri maupun bergrub, untuk mencari kesejahteraan dan kebahagiaan tersendiri dengan melakukan kegiatan wisata ke lingkungan hidup maupun dalam kegiatan sosial, budaya, serta ilmu dan alam (Riyanto, 
2018). Kedatangan orang yang berwisaya mengakibatkan adanya kegiatan sosial antara masyarakat yang membawa suatu perubahan dan adat istiadat masyarakat tersebut. Kegiatan pariwisata yang berkembang akan memberikan dampak baik secara langsung atau tidak secara langsung terhadapa kehidupan sosial dan perekonomian masyarakat disekitarnya (Mahanggainga, 2018).

Berdasarkan Undang-Undang Republik Indonesia Nomor 10 Tahun 2009 tentang Kepariwisataan disebutkan, yaitu:

1. Pariwisata adalah kegiatan perjalanan yang dilakukan oleh seseorang atau sekelompok orang dengan mengunjungi tempat-tempat tertentu untuk tujuan hiburan, pengembangan pribadi atau untuk mempelajari keunikan daya tarik wisata yang dikunjungi untuk sementara waktu. Wisatawan adalah orang yang ikut serta dalam kegiatan wisata.

2. Pariwisata adalah rangkaian kegiatan pariwisata dan didukung oleh berbagai fasilitas dan layanan yang disediakan oleh masyarakat, pengusaha, pemerintah dan pemerintah daerah

3. Pariwisata adalah kegiatan global yang berkaitan dengan pariwisata, bersifat multidimensi serta manusia dan negara serta interaksi antara wisatawan, pemerintah, otoritas lokal dan pengusaha.

4. Daya tarik wisata adalah segala sesuatu yang keunikan, keindahan, dan nilainya berupa berbagai kekayaan alam, budaya, dan buatan menjadi tujuan atau maksud kunjungan wisatawan. 
5. Daerah tujuan wisata/destinasi wisata adalah kawasan geografis yang berada dalam satu atau lebih wilayah administratif yang terdapat daya tarik wisata, fasilitas umum, fasilitas wisata, aksesibilitas, dan masyarakat yang saling melengkapi dalam mewujudkan kepariwisataan.

Oleh karena itu dapat disimpulkan bahwa menurut Undang-Undang Pariwisata No. 10 tahun 2009. Pariwisata adalah "rangkaian kegiatan pariwisata yang didukung oleh fasilitas dan pelayanan yang diberikan oleh masyarakat setempat, wisatawan lain, pemerintah, pemerintah daerah dan pengusaha (Aidar, 2017).

Sedangkan menurut Undang-Undang Penanggulangan Bencana Nomor 24 Tahun 2007, yang dijelaskan ialah suatu peristiwa yang dapat mengancam serta mengganggu untuk kehidupan masyarakat dikarenakan beberapa faktoe dari alam serta penyebab yang tidak jelas di faktor antropogenetik, yang dapat mengakibatkan hilangnya dari beberapa nyawa masyarakat, terjadinya kerusakan di lingkungan sekitarnya, kehilangan barang berharga serta efek psikologis.. Bencana dibagi menjadi 3 kelompok, ialah: bencana alam, bencana non-alam dan bencana sosial dari beberapa penjelasan di atas tersebut maka dapat disimpulkan bahwa bencana ialah suatu peristiwa yang dapat mengancam atau mengganggu keberlangsungan kehidupan manusia baik yang disebabkan oleh faktor alam maupun non-alam hingga menimbulkan kerugian mulai dari segi materi, kerusakan lingkungan, psikologis manusia, bahkan hingga korban jiwa (Sutrisnawati, 2020).

Wabah corona tentu saja membawa dampak di semua sektor industri yang ada di Indonesia. Dan keadaan yang tidak baik ialah di bidang pariwisata pada saat ini yang 
berkaitan dengan perhotelan, kegiatan transportasi atau biro perjalanan pariwisata, usaha besar, kecil, serta menengah atau yang disebut dengan (UMKM), terutama industri lainnya seperti oleh-oleh dan makanan, restoran, biro perjalanan dan pemandu wisata. Sejak Covid 19, untuk menyelamatkan Indonesia secara umum, khususnya industri pariwisata di Bali dan tempat wisata lainnya yang ada di Indonesia saat ini (Suciati, 2021).

Kegiatan awal yang dapat dilaksanakan untuk mengaktifkan kembali pariwisata ialah membuat kepercayaan terhadap masyarakat dengan perjalanan yang aman dan sehat. Melalui dari kementrian pariwisaya dan ekonomi kreatif dapat mengembangkan beberapa kegiatan dan program untuk mencegah wabah covid 19 dengan kegiatan new normal bertuuan dengan memulihkan bidang pariwisata. Program CHS (cleanliness, health and safety) ialah program yang dilakukan Kementerian Pariwisata dan Ekonomi Kreatif untuk beradaptasi dengan "new normal" di sektor pariwisata dan ekonomi kreatif. Program ini dibuat berdasarkan kondisi terkini saat virus Corona masih ada di masyarakat. Program CHS merupakan salah satu jawaban untuk mengatasi kecemasan wisatawan saat berkunjung ke suatu destinasi wisata. Wisatawan akan lebih memperhatikan protokol perjalanan terutama yang berkaitan dengan kesehatan, keamanan dan kenyamanan. Konsep CHS bidang pariwisata dan ekonomi kreatif mengacu pada proses kesehatan Kementerian Kesehatan, konsep pembangunan pariwisata berkelanjutan, dan Sapta Pesona. Tujuan dari program CHS ini adalah untuk meningkatkan kepercayaan pengunjung terhadap destinasi dan industri pariwisata Indonesia pascapandemi COVID-19 
guna mendorong peningkatan kunjungan wisatawan ke Indonesia (Sutrisnawati, 2020).

Cara tersebut dapat dilaksanakan dengan beberapa cara, antara lain sejumlah kebijakan pemerintah yang mendukung industri pariwisata, khususnya mendukung secara finansial atau mendorong biaya operasional, menetapkan SOP untuk mitigasi wisata alam, termasuk pandemi Covid 19 dengan menetapkan protokol kesehatan, dan menjaga kebersihan dan kesehatan di area kedatangan. , penguatan organisasi pengelola destinasi (DMO) khususnya pengelolaan desa wisata, peningkatan proses operasional pengelolaan daya tarik wisata, dari pengelolaan informasi hingga umpan balik wisatawan, produk-produk inovatif dengan membuat program perjalanan digital dan peningkatan rantai nilai, khususnya bagaimana cara mengelola pelanggan internal (karyawan yang puas) dan mempertahankan mereka sehingga mereka dapat memberikan layanan terbaik bagi wisatawan (Suciati, 2021).

Selain dengan melaksanakan kegiatan CHS Kementerian Pariwisata, sangat penting untuk melaksanakan prosedur medis yang telah dipandu oleh pemerintah melalui SK Menteri Kesehatan RI NO.HK.01.07/MENKES/382/2020 tentang protokol kesehatan bagi masyarakat di tempat dan fasilitas umum dalam rangka pencegahan dan pengendalian penyakit virus Corona 2019. Keputusan tersebut juga merinci protokol kesehatan di bisnis akomodasi seperti hotel/keluarga angkat/hotel, serta usaha jasa makanan yaitu restoran. Surat keputusan ini menjelaskan tindakan yang harus diambil oleh manajer, karyawan, dan tamu. Keterlibatan dan kedisiplinan manajemen, staf dan tamu dalam mengikuti 
protokol kesehatan ini sangat penting untuk merevitalisasi industri pariwisata dan menghindari virus corona (Sutrisnawati, 2020)

\section{Daftar Pustaka}

Aidar, Susanti. 2017. Dampak pariwisata terhadap pendapatan dan manfaat bagi masyarkat sekitar wisata alam. Jurnal ilmiah mahasiswa. Vol. 2. No 1 Februari 2017.

Mahangganga, Shantika. 2018. Dampak perkembangan pariwisata terhadap kondisi sosial ekonomi masyarakat. Jurnal destinasi pariwisata. Vol.0. no 0.

Riyanto, Primadany. 2018. Analisis strategi pengembangan pariwisata daerah. Jurnal administrasi publik. Vol. 1. No 4.

Solemede Nana, dkk. 2020. Strategi pemulihan potensi pariwisata budaya di provinsi Maluku. Jurnal Noumena. Vol.1 No 1.

Suciati, Suadiya. 2021. Strategi pemulihan pariwisata pasca pandemi covid 19 di provinsi Bali. Jurnal Maha Widya Duta. Volume 5. No. 1.

Sutisnawati ketut, dkk. 2020. Upaya pemulihan sektor pariwisata di tengah pandemi covid 19. Jurnal kajian dan terapan pariwisata. Vol 1. No 1.

WHO. 2020. Emergencies preparedness, response; what is a pandemic, diunduh tanggal 20 Juli 2020, tersedia di: https://www.who.int/csr/disease/swineflu/fre quently_asked_questions/pandemic/en/ 
Menyongsong PTMT Pada Dunia Pendidikan 


\title{
PERKEMBANGAN PASAR MODAL SYARIAH \\ INDONESIA MELALUI PASAR \\ MENABUNG SAHAM
}

\author{
Dini Selasi, S.E, M,M12 \\ Institut Agama Islam Bunga Bangsa Cirebon
}

"Program galeri investasi pasar sebagai pengenalan investasi saham masyarakat pasar dengan memberikan kesempatan para investor dari kalangan masyarakat"

B erinvestasi bisa dengan mudah dilakukan melalui dilihat dari road map pasar modal pada tahun 2015-2019; 90\% kurang memahami tentang investasi di pasar modal (Mubarok, 2018). Literasi dan inklusi pasar modal; literasi hanya sekitar 4,9 persen dan 1,55 persen untuk kegiatan inklusi pasar modal (Pratama, 2021) melalui PT Bursa Efek Indonesia pernah melakukan sosialisasi melalui gerakan 'Yuk Nabung Saham' (Filbert, 2017). Gerakan ini dilatar belakangi untuk menambah jumlah investor aktif masyarakat, menambah tingkat literasi tentang investasi di pasar modal juga merubah kebiasaan masyarakat menabung diubah menjadi investasi (yuknabungsaham,

12Penulis lahir di Cirebon, 18 Maret 1980, penulis merupakan Dosen Tetap Institut Agama Islam Bunga Bangsa Cirebon pada Fakultas Ekonomi dan Bisnis Islam Prodi ekonomi syariah, penulis menyelesaikan geral Sarjana Ekonomi di Universitas Pembangunan Nasional (UPN) Veteran Yogyakarta (2002), sedangkan gelar Magister Manajemen diselesaikan di Universitas Islam Kadiri (2003). 
2017). Menurut penelitian yang dilakukan oleh Muhammad Al Farido (Awwal \& Rini, 2019) bahwa hanya 0.2\% atau 600 ribu penduduk Indonesia yang ikut investasi kemudian melalui program nabung saham, program ini dalam jangka waktu satu tahun sudah meningkatkan inklusi pasar modal dari $0.1 \%$ menjadi $1.3 \%$.

GI BEI pada tahun 2016 mengeluarkan program Galeri Investasi Mobile (GIM) untuk memperluas literasi dan edukasi tentang pasar modal (OJK, 2016). Berdasarkan data dari IDX untuk pembentukkan GI BEI diseluruh Indonesia per Maret 2021 ada sebanyak 507 galeri investasi (IDX, 2021) lokasi yang digunakan tidak hanya di lingkungan kampus dan non kampus (Hogan, 2018) seperti pasar tradisional atau Pasar Nabung Saham. Kesadaran akan berinvestasi Indonesia masih sangat rendah jika dibanding dengan penduduk negara lainnya, tahun 2017 hanya 0,2\%; Malaysia 12,8\% atau 3,8 juta; Singapura ada sekitar 1,5 juta atau 30\%; China 13,7\% atau sudah 100,4 juta penduduknya berinvestasi di pasar modal (Kumparan, 2017). GI Indonesia berada di lingkungan non kampus; pasar tradisional yang mungkin tidak ada di negara lain yang berpotensi dalam menciptakan lapangan kerja (sebagai pedagang), mempunyai pendapatan tetap, banyak potensi pasar tradisional sebagai tempat untuk edukasi tentang investasi di pasar modal khususnya saham (Susanto, 2018). Kehadiran galeri investasi pasar sebagai tanda masyarakat bisa melakukan investasi saham, melakukan analisis saham, mengikuti perkembangan ekonomi, bisnis, sosial serta keadaan yang mempengaruhi pergerakan saham (fundamental), literasi keuangan Masyarakat pun meningkat dengan sendirinya (Shapiro \& Hanouna, 2019). 
Berikut adalah beberapa wilayah yang telah memiliki Galeri Investasi Pasar di Indonesia ;

Pasar Sepinggan Balikpapan, Kalimantan Timur; lokasinya ada di Kelurahan Sepinggan, Kecamatan Balikpapan Selatan, Kota balikpapan, Kalimantan Timur (Adhipratomo, 2018), bekerjasama antara PT. Phitraco Sekuritas, Dinas Perdagangan Kaltim, OJK Kaltim, Fakulta Ekonomi Universitas Balikpapan (WE Online, 2018) merupakan GI BEI pertama di Indonesia. GIP kedua diresmikan pada tanggal 8 Maret 2018 pasar menjadi tempat dalam perkembangan ekonomi, sebagai sarana literasi investasi, pasar merupakan tempat umum (Danty, 2018). Tercatat per 31 Januari 2018 jumlah investor di Kalimantan Timur; 8.813 SID, pasar tempat pergerakkan dan pertumbuhan ekonomi, pusat pemasaran produk lokal dapat menyerap keramaian masyarakat (indopremier, 2018), perputaran dana mencapai Rp. 17,2 miliar per bulannya dengan dominasi investor domestik 60\% dan 40\% investor asing pada tahun 2018 (Fadillah, 2018). Tahun 2020 GI BEI di Kalimantan Timur dan Kalimantan Utara ada 14 galeri investasi saham (Kaltim.procal, 2020).

Galeri Investasi Pasar Kamboja dan Galeri Investasi Pasar Bukit Kecil; pendirian galeri investasi di lingkungan pasar tradisional dan diharapkan literasi dan edukasi pasar modal (Muklis, 2016), perputaran dana setiap bulannya sebanyak Rp. 3,15 miliar, GIP yang ke empat (Kunnas, 2018). Pembukaan GIP di resmikan pada tanggal 14 Mei 2018 (Wulandari, 2018), bekerjasama PT Reliance Sekuritas Indonesia diharapkan masyarakat mengenal investasi di pasar modal (Tribunnews.com, 2018) merupakan GIP yang kelima (Kunnas, 2018) menjadi investor dapat menjadi 
pekerjaan tanpa mempunyai keahlian khusus sekalipun (Tribunnews.com, 2018).

Galeri Investasi Pasar Cikurubuk; terdiri dari 2.400 pedagang (OkeFinance, 2018). merupakan kerjasama antara; Universitas Siliwangi, PT Reliance Sekuritas Indonesia Tbk, Bursa Efek Indonesia (BEI) merupakan GIP pertama di Indonesia (Pemda Jabar, 2018). Menghasilkan pendapatan sebesar Rp.253,42 miliar pertahun sebagai Pendapatan Asli Daerah Kota Tasikmalaya dengan demikian potensi masyarakatnya besar sekali untuk berinvestasi di pasar modal (Wuryasty, 2018). Pasar Ujungberung (PD Pasar Bermartabat); kontribusi galeri investasi memberikan kontribusi yang besar terhadap jumlah investor $30 \%$ dengan usia para investor antara 17 tahun sampai dengan 35 tahun, para investor muda (Budianto, 2018). Untuk program galeri investasi pasar sebagai pengenalan investasi saham masyarakat pasar, memberikan kesempatan para investor dari kalangan masyarakat dimana lokasi PD Pasar Bermartabat (Kahfi, 2018).

\section{Daftar Pustaka}

Adhipratomo. (2018). BEI Resmikan Galeri Investasi Kedua di Pasar Tradisional. Retrieved June 7, 2021, from lantaibursa.id website: https://www.lantaibursa.id/2018/03/bei-resmikangaleri-investasi-kedua-di-pasar-tradisional/

Awwal, Muhammad Al Faridho, \& Rini, Dewi Wahyu Setyo. (2019). Peningkatan Sadar Investasi Masyarakat melalui Model Penta Helix. IQTISHODUNA, 15(2), 153-180.

Budianto, Arif. (2018, May 1). Pertama di Bandung, Galeri Investasi Hadir di Pasar Tradisional. Sindonews.Com. Retrieved from 
https://ekbis.sindonews.com/berita/1302210/32/perta ma-di-bandung-galeri-investasi-hadir-di-pasar-tradisional Danty, Rahma. (2018). Beli Saham Sekarang Bisa di Pasar Sepinggan. Retrieved June 7, 2021, from inibalikpapan.com website:

https://www.inibalikpapan.com/beli-saham-sekarangbisa-di-pasar-sepinggan/

Fadillah, Fariz. (2018, March 9). Pacu Jumlah Investor, BEI Sasar Pasar Tradisional di Balikpapan. Bisnis.Com. Retrieved from https://kalimantan.bisnis.com/read/20180309/408/748 073/pacu-jumlah-investor-bei-sasar-pasar-tradisional-dibalikpapan

Filbert, Ryan. (2017). "Yuk Nabung Saham" adalah Kampanye Menyesatkan? Kompas.Com. Retrieved from https://ekonomi.kompas.com/read/2017/11/28/120000 726/-yuk-nabung-saham-adalah-kampanyemenyesatkan-?page=all

Hogan, Nicky. (2018). Indonesia Nabung Saham. Retrieved June 11, 2020, from TICMI-Kampungpasarmodal.com website: https://kampungpasarmodal.com/article/detail/62/indonesia-nabung-saham-

IDX. (2021). Data GI BEI per Maret 2021. Retrieved June 11, 2021, from idx.co.id website: https://www.idx.co.id/media/9762/20210331-databasegi-bei.pdf

indopremier. (2018). Galeri Investasi Hadir di Pasar Sepinggan. Retrieved June 7, 2021, from Indopremier.com website: https://www.indopremier.com/ipotnews/newsDetail.ph p?jdl=Galeri_Investasi_Hadir_di_Pasar_Sepinggan\&news_i $d=330094$ \&group_news $=$ RESEARCHNEWS\&news_date $=\&$ taging_subtype=PROPERTY\&name $=\&$ search=y_general $\& \mathrm{q}$ =pasar tradisional, \&halaman=1

Kahfi. (2018, March 1). Warga Ujung Berung Mau Jadi Investor Saham, Silahkan Datang ke Pasar. Bisnis.Com. Retrieved from

https://bandung.bisnis.com/read/20180501/550/11119 
98/warga-ujung-berung-mau-jadi-investor-sahamsilahkan-datang-ke-pasar

Kaltim.procal. (2020). Literasi Pasar Modal Meningkat, Investor Bisa Tumbuh Dua Digit. Retrieved June 7, 2021, from kaltim.procal.co website: https://kaltim.prokal.co/read/news/365967-literasipasar-modal-meningkat-investor-bisa-tumbuh-duadigit $/ 6$

Kunnas, Jawarul. (2018). BEI Resmikan Dua Galeri Investasi Pasar di Palembang. Retrieved June 7, 2021, from ivoox.id website: https://ivoox.id/bei-resmikan-dua-galeriinvestasi-pasar-di-palembang/

Kustina, Lisa. (2020). Meningkatkan Pendapatan Masyarakat Melalui Investasi. KOMMAS: Jurnal Pengabdian Kepada Masyarakat, 1(1).

Mubarok, Ferry Khusnul. (2018). Peran sosialisasi dan edukasi dalam menumbuhkan minat investasi di pasar modal syariah. INOVASI, 14(2), 113-122.

Muklis, Faiza. (2016). Perkembangan dan tantangan pasar modal Indonesia. Al-Masraf: Jurnal Lembaga Keuangan Dan Perbankan, 1(1), 65-76.

OJK. (2016). Galeri Investasi Mobile. Retrieved December 9, 2018, from www.sikapiuangmu.ojk.go.id/frontend/cms/article/1038 1

OkeFinance. (2018). Galeri Investasi Pasar Pertama di Indonesia Ada di Cikurubuk Tasikmalaya. Retrieved June 11, 2021, from economy.okezone.com website: https://economy.okezone.com/read/2018/02/13/278/1 858905/galeri-investasi-pasar-pertama-di-indonesia-adadi-cikurubuk-tasikmalaya

Pemda Jabar. (2018). Galeri Investasi BEI Pertama di Indonesia Hadir d Pasar Cikurubuk Tasikmalaya. Retrieved June 11, 2020, from jabarprov.go.id website: https://jabarprov.go.id/index.php/news/27450/2018/0 2/12/Galeri-Investasi-BEI-Pertama-di-Indonesia-Hadir-dPasar-Cikurubuk-Tasikmalaya 
Pratama, Aditya. (2021). Baru 4,9 Persen, Literasi Pasar Modal Terus Digenjot. Retrieved from https://www.idxchannel.com/economics/baru-49persen-literasi-pasar-modal-terus-digenjot

Shapiro, Alan C., \& Hanouna, Paul. (2019). Multinational financial management. John Wiley \& Sons.

Susanto, Rahmad Yusuf. (2018). Potensi Pasar Tradisional Blimbing bagi Masyarakat di Sekitar Kecamatan Lowokwaru Kota Malang. Jurnal Referensi: Ilmu Manajemen Dan Akutansi, 6(2), 39-47.

Tribunnews.com. (2018, May 15). Lagi, Reliance Buka Galeri Investasi di Dua Pasar Tradisional. Kontan.Co.Id. Retrieved from https://keuangan.kontan.co.id/news/lagi-reliancesekuritas-buka-galeri-investasi-di-dua-pasartradisional?page=all

WE Online. (2018, March 8). Dirut BEI Resmikan Galeri Investasi Pertama di Pasar Tradisional Balikpapan. Wartaekonomi.Co.Id. Retrieved from https://www.wartaekonomi.co.id/read172976/dirut-beiresmikan-galeri-investasi-pertama-di-pasar-tradisionalbalikpapan

Wulandari, Dinda. (2018, May 14). BEI Palembang Perluas Jangkau Investor Buka Galeri di Pasar Tradisional. Sumatera.Bisnis.Com. Retrieved from https://sumatra.bisnis.com/read/20180514/534/79498

3/bei-palembang-perluas-jangkau-investor-buka-galeridi-pasar-tradisional

Wuryasty, Fetry. (2018, February 12). BEI Resmikan Galeri Investasi Pertama di Pasar Tradisional. Media Indonesia. Retrieved from https://mediaindonesia.com/ekonomi/144997/beiresmikan-galeri-investasi-pertama-di-pasartradisional.html yuknabungsaham. (2017). Yuk Nabung Saham. 
Menyongsong PTMT Pada Dunia Pendidikan 


\section{MEMAHAMI DASAR DASAR AKUNTANSI UNTUK PEMULA}

\section{Almira Keumala Ulfah, M.Si., Ak., CA ${ }^{13}$ \\ IAIN Lhokseumawe}

"Memahami dasar akutansi dengan mengembangkan pedoman untuk mempelajari akuntansi, seperti persamaan akuntansi, penjurnalan, posting ke buku besar, dan neraca"

$\mathrm{D}$ asar-dasar pembukuan perlu dipahami oleh mereka yang tidak mengerti pembukuan. Akuntansi merupakan bidang ilmu yang digunakan dalam semua bidang pekerjaan. Secara umum, ilmu akuntansi berkaitan dengan penggunaan pengukuran, pemberian penjelasan, dan jaminan informasi keuangan yang nantinya akan dibagikan kepada pihak-pihak terkait. Dengan mengetahui dasar-dasar akuntansi, Anda dapat mengetahui istilahistilah keuangan dan cara menyusun laporan keuangan.

13Penulis lahir di Medan, 28 Juli 1988. Penulis merupakan dosen Akuntansi di Program Studi Hukum Ekonomi Syariah, Fakultas Syariah, IAIN Lhokseumawe. Pada tahun 2011 dia mendapatkan gelar sarjananya di Fakultas Ekonomi dan Bisnis UNSYIAH jurusan Akuntansi. Pada tahun 2013 dia menyelesaikan pendidikan profesi akuntansi di Program Pendidikan Akuntansi UNSYIAH, dan pada akhir tahun 2015 dia menyelesaikan magister akuntansi di UNSYIAH. Penulis menjadi dosen akuntansi pada tahun 2016, sebagai dosen akuntansi di Politeknik Kuta Raja sekaligus menjadi sekretaris Program Studi Diploma III Politeknik Kutaraja. Sebelum menjadi seorang dosen, Penulis adalah seorang kepala akuntan di PT Sharp Electronik Indonesia cabang aceh. Penulis adalah seorang praktisi yang bergerak dibidang akuntansi dan sekaligus dosen akuntansi. 
Pada dasarnya, akuntansi dasar menyangkut pengukuran, penjabaran, atau kepastian informasi keuangan yang dibagikan kepada pihak-pihak terkait, untuk tujuan mengevaluasi perusahaan atau pemilik bisnis. Sebagai pemilik bisnis, kita dapat mempelajari lebih lanjut tentang akuntansi untuk melacak kesehatan bisnis kami. Memahami pembukuan dasar memungkinkan para pengusaha dan pengusaha UKM untuk memperhatikan menjalankan usahanya. Bahkan jika kita bukan seorang pengusaha atau pemilik usaha kecil, belajar akuntansi juga dapat membantu kita mengelola keuangan.

Akuntansi adalah ilmu pengumpulan data, klarifikasi data, peringkasan data, pengolahan data, dan penyajian data. Atau dapat diartikan sebagai segala transaksi yang berhubungan dengan uang. Tujuannya adalah untuk memfasilitasi pengambilan keputusan dan memungkinkan orang dan bisnis untuk mengambil langkah selanjutnya untuk pekerjaan mereka. Tentu saja, untuk mempelajari akuntansi, sangat perlu untuk memahami tujuan akuntansi itu sendiri.

Akuntansi merupakan media yang digunakan oleh para pelaku bisnis untuk menyampaikan informasi berupa data keuangan untuk keperluan pengambilan keputusan agar mudah dipahami oleh banyak orang. Selain itu, catatan akuntansi dapat digunakan sebagai dasar untuk menghitung pajak perusahaan dan menetapkan pedoman tata kelola perusahaan. Akuntansi memungkinkan perusahaan untuk mengidentifikasi informasi tentang keuntungan atau kerugian perusahaan selama periode akuntansi. Untuk itu, sangat penting untuk memahami prinsip-prinsip akuntansi tersebut agar dapat memperoleh manfaat yang maksimal dari akuntansi. 
Untuk menjadi seorang akuntan profesional, diperlukan untuk dapat memahami ap aitu dasar akuntansi. Dasar akuntansi adalah mengembangkan pedoman untuk mempelajari akuntansi, seperti persamaan akuntansi, penjurnalan, posting ke buku besar, dan neraca. Semua itu harus disajikan. Untuk menerapkan persamaan akuntansi dasar, harus mematuhi prinsip-prinsip akuntansi. Prinsipnya adalah keseimbangan antara aset dan kewajiban. Persamaan dasar akuntansi menganalisis laporan keuangan dan semua transaksi yang terjadi. Departemen akuntansi memeriksa debit dan kredit dari semua transaksi. Oleh karena itu, perlu untuk memperoleh pengetahuan ini agar prinsip keseimbangan dapat terwujud. Aset atau harta kekayaan adalah harta kekayaan yang dimiliki oleh perusahaan atau kadang disebut sebagai harta kekayaan, dan hak atas harta kekayaan tersebut disebut dengan hak milik (persamaan). Hubungan antara aset dan hak aset dapat dinyatakan dengan rumus berikut. Hubungan antara harta dan hak milik dapat dinyatakan dengan rumus berikut.

\section{Harta (assets) = Hak atas kekayaan (equality)}

Pengertian persamaan dasar akuntansi adalah hubungan antara aktiva, kewajiban, dan modal perusahaan. Ini berfungsi sebagai dasar untuk pencatatan dalam akuntansi. Artinya, setiap transaksi harus dicatat pada dua sisi: sisi kiri (harta) dan sisi kanan (kewajiban). Persamaan dasar akuntansi adalah keseimbangan antara aset dan kewajiban. Ketika terjadi perubahan sebagai akibat dari transaksi keuangan, keseimbangan harus selalu dijaga. Ini adalah dasar dari proses entri jurnal dalam proses akuntansi. Berikut bentuk dari persamaan dasar akuntansi:

Aset $($ aktiva $)=$ Kewajiban $($ pasiva $)+\operatorname{Modal}($ pasiva $)$ 
Aset itu sendiri adalah aset yang mewakili sumber daya ekonomi yang memiliki nilai guna bagi suatu organisasi atau perusahaan. Kewajiban terdiri dari hutang. Modal yaktu modal usaha atau modal kerja. Transaksi dicatat dalam catatan akuntansi dan dikelompokkan menurut kategori tertentu. Berdasarkan kategori cakupan, akuntansi memiliki lima komponen utama:

\section{Assets (Harta)}

Assets adalah salah satu harta berharga milik perusahaan. Oleh karena itu, aset adalah harta perusahaan yang memiliki nilai moneter atau dapat diubah menjadi uang, baik yang terlihat maupun yang tidak terlihat, dan berguna untuk masa depan perusahaan. Kekayaan bersih perusahaan dibagi lagi menjadi beberapa bagian, yaitu:

\section{a. Current Assets (Harta Lancar)}

Harta lancar adalah harta yang waktu pencairannya kurang dari satu tahun. Harta lancar dapat disebut juga sebagai harta dengan likuiditas tinggi. Contoh dari harta lancar, yaitu kas, piutang usaha, persediaan barang dagangan, dan perlengkapan. Berikut ini adalah contoh akun yang termasuk harta lancar:

Harta lancar terdiri dari uang kertas, uang logam, dan kertas berharga yang sifatnya sama seperti uang.

b. Fixed Assets (Harta Tetap)

Harta tetap berarti ada bentuknya untuk kegiatan operasional perusahaan digunakan lebih dari satu tahun dan tidak untuk dijual. Contohnya, 
gedung, mesin (peralatan), kendaraan operasional perusahaan, tanah, dan lain-lain.

c. Intangible Assets (Harta Tak Berwujud)

Harta tak berwujud adalah harta yang tidak memiliki wujud tetapi digunakan oleh perusahaan untuk mendapatkan keuntungan, seperti hak cipta dan hak paten.

2. Liabilities (Kewajiban atau Utang)

Tahukah kamu apa itu liabilities? Liabilities adalah kewajiban perusahaan untuk membayar sejumlah uang tertentu kepada pihak lain. Salah satu sumber kekayaan pada sebuah perusahaan berasal dari orang-orang yang memberi pinjaman (kreditur), berikut akun berupa jenis-jenis utang:

a. Utang Lancar

Seperti harta lancar, utang lancar wajib dilunasi dalam jangka waktu kurang dari satu tahun. Contoh dari akun lancar, yaitu:

b. Utang usaha adalah utang yang biasanya karena perusahaan membeli barang dengan cara kredit. Beban yang masih harus dibayar. Intinya, perusahaan menggunakan manfaatnya terlebih dahulu sebelum membayar, seperti utang gaji, perusahaan sudah mendapatkan manfaat dari karyawan yang setiap hari bekerja, tetapi perusahaan baru akan bayar saat akhir bulan.

Pendapatan diterima di muka. Kalo yang ini, perusahaan menerima uang terlebih dahulu baru dikerjakan. Jadi, perusahaan memiliki utang ke klien untuk mengerjakan kerjaannya. 
c. Utang Jangka Panjang adalah utang yang pelunasannya lebih dari satu tahun, dan biasanya di atas tiga tahun. Contoh utang jangka panjang, yaitu:

d. Utang obligasi. Ini adalah utang yang dilakukan sebuah perusahaan dalam membeli surat obligasi. Utang hipotek. Ini adalah utang yang dilakukan menggunakan jaminan. Kalau kamu pernah main board game monopoly, ada istilah hipotek, bukan? Jadi, kalau kamu meminjam uang ke bank menggunakan jaminan misalnya, bangunan milik pribadi dan ketika kamu tidak bisa membayar, maka bank berhak untuk menyita jaminan tersebut sebagai ganti utangnya.

\section{Equity (Ekuitas atau Modal)}

Kewajiban perusahaan terhadap pemilik modal yang menanamkan modalnya ke perusahaan. Segala sesuatu yang dimiliki sebuah perusahaan untuk menunjang kinerja dan jalannya sebuah perusahaan tersebut tergolong modal. Jadi selain uang tunai dapat berupa tempat usaha, mesin, komputer, dan lain-lain. Sumber modal dibagi menjadi dua, yaitu:

Modal Internal, yaitu modal yang didapatkan sendiri, dan bisa dari hasil keuntungan, atau memang milik pribadi dari awal. Modal Eksternal, yaitu modal yang didapatkan dari sumber luar, seperti pinjaman bank.

4. Income (Pendapatan)

Pendapatan adalah nominal yang didapatkan oleh sebuah perusahaan dari hasil penjualan barang atau 
jasa. Pendapatan bisa juga didapat dari sewa atau bunga. Jika perusahaan menyewakan tempatnya, pasti mendapatkan uang, dan itu masuk ke pendapatan (sewa) atau jika perusahaan meminjamkan uang ke pihak lain dan mendapatkan bunga itu disebut juga pendapatan (bunga). Jadi, pendapatan ada yang berasal dari kegiatan usaha, seperti jual-beli barang dagangan, dan pendapatan di luar usaha, seperti yang tadi sudah disebutkan di atas, yaitu pendapatan sewa dan pendapatan bunga.

5. Expenses (Biaya/Pengeluaran atau Beban)

Uang yang dikeluarkan perusahaan untuk membiayai operasional usaha. Nah, ini kebalikan dari pendapatan. Segala nominal yang dikeluarin sebuah perusahaan untuk menjalankan usaha disebut beban. Contohnya, yaitu:

Adanya Beban gaji, yaitu beban untuk membayar gaji karyawan sebuah perusahaan. Beban sewa, misalnya untuk bayar sewa gedung atau alat. Beban bunga, yaitu beban perusahaan untuk bayar bunga, seperti bunga utang bank.

\section{Daftar Pustaka}

Abidin, Jaenal, Ayumi Rahma, and Budi Tri Santoso. "PENGENALAN AKUNTANSI UNTUK BISNIS PEMULA." Jurnal Industri Kreatif dan Kewirausahaan 2.2 (2019).

Bachtiar, Irmah Halimah. Akuntansi Dasar Buku Pintar Untuk Pemula. Deepublish, 2019.

Khabibah, Nur, and Agus Wahyudin. "Pengaruh Pemahaman Analisis Transaksi, Persamaan Dasar Akuntansi dan Konsep Debit Kredit terhadap Hasil Belajar Jurnal 
Penyesuaian dengan Kemampuan Berpikir Deduktif sebagai Variabel Moderating." Economic Education Analysis Journal 9.1 (2020): 182-199.

Mauliyah, Nur Ika, and Endah Masrunik. DASAR AKUNTANSI: Suatu Pengantar. Penerbit NEM, 2019.

Psi, Devy Sofyanty S., et al. "DASAR-DASAR AKUNTANSI."

Ulfah, Almira Keumala. "Persamaan Akuntansi dalam Transaksi Bisnis." J-ISCAN: Journal of Islamic Accounting Research 2.1 (2020): 45-54.

Ulfah, Almira Keumala. "Double Entry Bookkeeping Dalam Akuntansi." J-ISCAN: Journal of Islamic Accounting Research 1.1 (2019): 1-14.

Ulfah, Almira Keumala, et al. "Accounting Equations in Business Transactions." Psychology and Education Journal 57.8 (2020): 456-460. 


\title{
ONLINE SHOP: \\ POLA BISNIS AMAN PASCAPANDEMI \\ (STUDI ELLIN HIJAB \\ DESA PRAJAWINANGUN WETAN \\ KABUPATEN CIREBON)
}

\author{
Cory Vidiati, S.H., M.M14 \\ IAI Bunga Bangsa Cirebon
}

"Pemasaran digital cenderung gratis, mudah ditangani dan dikelola dan memungkinkan interaktivitas dengan audiens target yang tepat, sehingga produk dapat diminati"

\section{Pendahuluan}

Covid-19 mengubah banyak aspek mulai dari gaya hidup/tatanan sosial-budaya (Vidiati, 2021, p. 125), pendidikan, ekonomi, dan bisnis. Transformasi besar di antaranya, berpusat pada teknologi informasi, tren ini bertanggung jawab atas perubahan dalam lingkup konsumsi, promosi, kemitraan, intensifikasi bisnis jaringan, komersial, produksi, dan inovasi. Dalam konteks inovasi dan

${ }^{14}$ Cory Vidiati, lahir di Cirebon 1975, latar belakang pendidikan S1 Ilmu Hukum di Universitas Sebelas Maret-Surakarta lulus tahun 1998; S2 di Sekolah Tinggi Ilmu Ekonomi Widya Jayakarta-Jakarta, lulus tahun 2001; dan kandidat Doktor Hukum Islam, konsentrasi Hukum Ekonomi Syariah di UIN Sunan Gunung Djati Bandung, angkatan 2017; memulai karir mengajar pada tahun 2004, dan saat ini dosen Fakultas Ekonomi dan Bisnis Islam, Prodi Ekonomi Syariah di IAI Bunga Bangsa Cirebon. Bebarapa pengalaman kerja pernah dikerjakan, kepala kantor perusahaan batubara, financial advisor perusahaan asuransi, dan aktif sebagai konsultan lingkungan hidup. 
transformasi, internet memberikan pengetahuan dan informasi, memfasilitasi hubungan pribadi, membuka saluran komunikasi baru dalam organisasi, mengembangkan saluran interaksi antara pelanggan dan perusahaan, antara produsen dan konsumen dan, menciptakan bentuk baru perdagangan atau transaksi komersial. Pentingnya pemasaran digital dalam strategi bisnis, dapat berkontribusi pada manajemen model bisnis yang efektif karena sebagian besar ancaman dan peluang saat ini muncul dari internet itu sendiri (Helsen, 2019). Kondisi ini mengharuskan produsen untuk menerapkan strategi loyalitas dan konsolidasi untuk pelanggan saat ini dan menarik pelanggan baru.

Dalam lingkungan virtual ini, konsumen memiliki otonomi yang lebih besar untuk membandingkan produk. Di lain pihak, pemasaran digital memungkinkan produsen untuk mengakses pasar global, lebih kompetitif, dan menguntungkan, Covid-19 dapat mempengaruhi esensi fundamental dan perkembangan pemasaran, menawarkan bisnis peluang bagus untuk beralih ke pemasaran nyata dan jujur yang benar-benar dapat mengatasi tantangan lingkungan dan sosial yang mendesak secara global, pandemi Covid-19 telah memungkinkan perusahaan untuk ubah strategi pemasaran mereka menjadi pemasaran yang nyata dan jujur, mampu memenuhi yang muncul tantangan lingkungan dan sosial di seluruh dunia.

Pemasaran digital memiliki beberapa keunggulan. Itu berarti kemampuan beradaptasi, efisiensi biaya, keandalan, tetap terdepan dalam persaingan, dan meningkatkan keterlibatan konsumen dengan Covid19. Ada beberapa hal yang bisa dilakukan bisnis online melalui digital marketing. Ini menarik pelanggan baru, terhubung dengan peserta yang 
lebih luas dan tersebar secara geografis, membongkar produk baru, mendiskusikan tren pasar, dan pada saat yang sama mengirimkan produk ke konsumen. Adanya blog atau situs web perusahaan yang menambah nilai merek dengan memberikan informasi produk, juga dapat digunakan untuk optimasi mesin pencari, branding, dan membangun kepercayaan konsumen. Strategi pemasaran digital yang lain adalah menggunakan pemasaran email untuk meningkatkan visibilitas bisnis, meningkatkan loyalitas pelanggan, dan secara pribadi mempromosikan produk. Gunakan Google Bisnisku dan Whatsapp Bisnis sebagai alat pemasaran digital untuk memfasilitasi komunikasi dengan pelanggan.

Toko online yang semakin populer di tengah pandemi, selama ini banyak diminati. Dari observasi lapangan pada Ellin Hijab Desa Prajawinangun Wetan Kec. Kaliwedi Kabupaten Cirebon, bahwa terjadi transformasi bisnis konvensional yang dijalani sebelum pandemi, dan total berbisnis secara jaringan saat pandemi hingga sekarang. Dan penjualan bulanan mencapai 1000 buah per produk.

\section{Pembahasan}

Awalnya dikenal sebagai komunitas "Desa Pengemis" dan "Punk", Desa Prajawinangun Wetan mulai berubah menjadi desa digital. Peralihan tersebut bermula dari kehadiran Ellin Hijab yang memulai bisnis secara konvensional di tahun 2016. Konjungtur sosial-ekonomi yang disebabkan oleh Covid 19 mempengaruhi implementasi strategi digital marketing oleh pelaku bisnis retail. Termasuk Ellin Hijab, yang menggunakan digital semenjak pandemik untuk strategi pemasarannya. Mereka menargetkan pasar tersegmentasi yakni menggunakan adanya dua merek dagang yang dikenalkan yakni Ellin Hijab 
\& PPG; dimana Ellin Hijab dikhususkan untuk segmen pasar menengah ke atas, dan PPG mensegmentasikan pasar menengah ke bawah. Perbedaan antara Ellin Hijab maupun produk PPG terletak pada kualitas bahan, kualitas jahitan, model, dan packaging. Tujuannya meningkatkan jumlah pelanggan dan menarik pelanggan baru.

Wawancara di lokasi memperlihatkan dinamika, meskipun terlihat subyektif, berdasarkan kesadaran, keterbukaan, dan pengakuan keuntungan potensial pelaku usaha. Dan dengan implementasi strategi pemasaran digital ini, menemukan ritme menguntungkan bagi usaha. Dari responden menyatakan bahwa mereka telah menggunakan beberapa pemasaran digital strategi sebelum munculnya Covid 19, seperti whatsapp walau belum optimal kala itu, sebagai upaya untuk mengadopsi atau meningkatkan strategi ini. Untuk strategi pengendalian biaya, mereka cenderung gunakan anggota keluarga, teman, atau kenalan yang mengetahui bidang pemasaran digital dan otodidak berdasarkan pengalaman; pelatihan digital marketing dilakukan saat awal peralihan.

Ellin Hijab menjadi generasi pemimpin di wilayah ini dengan mengetoktularkan kemampuan bertransaksi secara digital pada warga lain sehingga saat pandemi pun sektor ekonomi desa tetap berjalan normal. Jejaring sosial yang digunakan Ellin Hijab diantaranya Blog, FB, Instagram, WA Grup, Telegram, dan marketplace yang digunakan Shopee, Lazada, dan Tokopedia. Alasan adopsi jejaring sosial ini sebagai sarana di mana inti strategi pemasaran digital perusahaan umumnya didasarkan biaya keanggotaan nol, potensi untuk memberikan penjualan, kemudahan penggunaan, jangkauan arus audiens yang secara teoritis 
tidak terbatas atau potensial, potensi penciptaan prospek, dan umpan balik seperti CTA-Call to Action.

Guna memitigasi resiko, Ellin Hijab lebih menggunakan pendekatan whatsapp grup bagi reseller, agen, maupun pelanggan setianya. Dan terbukti komplain relatif rendah. Ketika ada komplain, yang dilakukan admin Ellin Hijab adalah menelpon konsumen, dan menawarkan solusi berupa retur ataupun refund, bergantung keinginan konsumen. Penjadwalan produk di sosmed pun tertib dilakukan oleh admin secara berkala; produk baru pun dikeluarkan secara berkala. Tentang konten, ada keragaman besar, dan dimungkinkan untuk menemukan kesaksian yang mengarah ke penggunaan teks, gambar, suara, video langsung, dan foto artistik. Ada juga kecenderungan untuk ini publikasi untuk dikaitkan dengan peringatan atau konteks lain yang memanfaatkan komunikasi untuk tingkat ketenaran.

Treatment bagi agen, reseller, dan konsumen setia dilakukan oleh Ellin Hijab dengan memberikan give away saat launching produk baru dan bonus, yang ditentukan dengan kriteria yang sudah ditentukan. Kenyamanan karyawan bekerjapun diperhatikan Ellin Hijab dengan memberikan gaji di atas upah minimum kabupaten (UMK) Cirebon; bonus (dengan syarat dan ketentuan khusus); juga layanan kesehatan. Sehingga dimungkinkan membentuk indikator loyalitas pelanggan termasuk loyalitas karyawan pada Ellin Hijab ini. Ada juga tren penerapan inisiatif tindak lanjut pelanggan di pasca-penjualan dan menentukan derajat kepuasan pelanggan.

Dengan menggunakan digital marketing online shop, Ellin Hijab mampu mengubah paradigma desa menjadi desa digital dengan mengedukasi bagi yang berminat menekuni 
bisnis online ini, hingga total penduduk yang menekuni bisnis online kini mencapai $80 \%$. Dengan omzet rata-rata perbulan 25-30juta. Dukungan pemerintah desa guna menjaga kondusifitas dan keberlanjutan proses online ini direalisasikan oleh Kuwu dengan menerbitkan kebijakan berupa SK sebagai dasar kegiatannya (Islah, 2021).

Diakhir wawancara dengan pelaku usaha, bahwa bisnis online ini lebih membuat tenang, aman, praktis, murah, tidak terikat waktu dan tempat/fleksibel, dan mampu menghasilkan omzet tinggi dibandingkan penjualan konvensional.

\section{Simpulan}

Efek berbahaya yang disebabkan oleh pandemi Covid19, yang tidak disadari oleh pelaku usaha, adalah kesiapan menggunakan tehnologi digital untuk pemasarannya. Secara bertahap, usaha pemasaran konvensional cenderung melepaskan inisiatif terisolasi yang terkait dengan pemasaran tradisional untuk mempromosikan aktivitas dan produk mereka dan cenderung menggabungkan inisiatif terkait dengan pemasaran digital. Ellin Hijab, di masa sebelum Covid-19 di tahun 2016 melakukan pemasaran konvensional, kekuatan pendorong di balik perubahan ini berpusat pada kebutuhan untuk menemukan keberlanjutan bisnis dan mengurangi sebanyak mungkin kerugian yang dihasilkan dari kegiatan komersial yang dikerjakan, dan memberikan rasa aman tanpa kontak fisik langsung dengan agen, reseller, dan konsumen.

Dalam konteks ini, alat pemasaran digital cenderung gratis, mudah ditangani dan dikelola dan memungkinkan interaktivitas dengan audiens target yang tepat, sehingga produk jadi diminati. Namun demikian, manfaat yang timbul dari pelaksanaan inisiatif yang terkait dengan pemasaran 
digital ini diakui, namun keuntungan tidak cukup untuk mengkompensasi kerugian yang terkait dengan model bisnis baru, hanya faktor keamanan dimana terhindar dari kontak fisik atas produk seperti pada penjualan konvensional. Implementasi pemasaran digital menjadi strategi Ellin Hijab, dengan melihat beberapa inisiatif yang dipertimbangkan dibidang ini sehingga dapat digunakan di masa darurat sosial. Dukungan pun di dapat dari pemerintah desa dengan mengatur sistem pemasaran online yang sehat dan berkelanjutan.

\section{Daftar Pustaka}

Helsen, K. (2019). Digital Marketing in The Global Marketplace: Latest Developments. 24.

Islah. (2021, March 30). Prajawinangun Wetan jadi Kampung Online. Suara Cirebon. https://suaracirebon.com/2021/03/30/prajawinangunwetan-jadi-kampung-online/

Vidiati, C. (2021). Kajian Sosial Budaya: Suatu Implementasi Nilai Kerakyatan yang Bersumber dari Pancasila Mengatasi Pandemi COVID-19. In Akselerasi SDM Unggul Saat Pandemi (1st ed., p. 125). Akademia Pustaka. 
Menyongsong PTMT Pada Dunia Pendidikan 


\title{
UPAYA MENGATASI MISKONSEPSI BELAJAR AKUNTANSI PADA MASA PEMBELAJARAN TATAP MUKA TERBATAS
}

\author{
Shelly Midesia, S.E., Ak., M.Si. ${ }^{15}$
}

IAIN Langsa

"Meningkatkan keberhasilan penyerapan materi akuntansi, mahasiswa diajak untuk ikut memberikan pendapat bagaimana cara mudah mereka memahami materi dengan cara merumuskan kontrak perkuliahan"

\section{Pendahuluan}

Tulisan ini bertujuan untuk menjelaskan upaya 1 mengatasi miskonsepsi dalam proses belajar dan mengajar akuntansi yang dikumpulkan dari pengalaman selama mengajar di Fakultas Ekonomi dan Bisnis Islam, IAIN Langsa pada masa pandemi Covid-19. Pengalaman dalam kegiatan mengajar, berdiskusi dengan mahasiswa, dan berbagai diskusi dengan rekan-rekan sesama pengajar selama masa pandemi ini, bahwa proses pembelajaran akuntansi pada masa pembelajaran tatap muka terbatas mengalami beberapa miskonsepsi pada mahasiswa dan

15Penulis lahir di Meulaboh, 12 November 1990, penulis merupakan Dosen IAIN Langsa dalam bidang ilmu Akuntansi, penulis menyelesaikan gelar Sarjana Ekonomi pada Program Studi Akuntansi di Univeristas Syiah Kuala (2012), mengambil Program Pendidikan Profesi Akuntansi (PPAk) di Universitas Syiah Kuala (2013) dan menyelesaikan gelar Magister Akuntansi di Universitas Syiah Kuala (2016). 
untuk itu dosen diharuskan mengambil beberapa upaya untuk mengatasi miskonsepsi yang sedang terjadi ini.

\section{Miskonsepsi Belajar Akuntansi}

Konsepsi merupakan pemahanan yang keliru, yaitu konsep seseorang yang tidak sesuai dengan ilmiah yang sebenarnya. Miskonsepsi ini harus segera diatasi, karena akan berakibat pada hasil belajar siswa dan akan mengalami ketidaktuntasan hasil belajar pada pelajaran akuntansi. Tidak hanya ketidaktuntasan hasil belajar, miskonsepsi pada materi awal akuntansi akan berpengaruh pada materi-materi selanjutnya, seperti dalam pembuatan kertas kerja (worksheet) dan juga akan berpengaruh terhadap laporan keuangan. Dengan demikian, siswa harus benar-benar dalam memahami konsep jurnal penyesuaian ini (Yuniarti, 2013).

Tidak seperti pelajaran matematika yang menghitung angka-angka sesuai dengan rumus yang baku, pada ilmu akuntansi dikhawatirkan miskonsepsi lebih sering terjadi dikarenakan angka-angka yang dihitung pada akuntansi mengikuti dari bermacam-macam transaksi yang terjadi mengikuti jenis usaha perusahaannya. Tidak semua perusahaan bergerak dibidang usaha yang sama. Diperlukan pemahaman konsep ilmu akuntansi yang jelas, sehingga mahasiswa mampu memahami siklus akuntansi secara keseluruhan serta mampu membuat dan menganalisis laporan keuangan perusahaan.

\section{Sikap Mahasiswa Dalam Proses Belajar}

Sering kali penyampaian materi perkuliahan pada proses belajar dan mengajar dihambat oleh mindset mahasiswa yang hanya peduli dengan nilai yang bisa didapat dengan cara bersantai. Kita sebagai pegajar perlu 
meluruskan pola pikir para mahasiswa tersebut. Nilai optimal didapat dari pemahaman materi yang dikuasi oleh mahasiswa yang dibuktikan dengan soal ujian yang dijawab benar. Bagaimana bisa mahasiswa memperoleh nilai yang maksimal jika tidak bisa memahami materi yang sudah dibahas di kelas. Pada masa pandemi, perkuliahan dilaksanakan secara online melalui zoom, siakad atau edlink, tetapi dalam pelaksanaannya mahasiswa sering kali beralasan dengan menyalahkan jaringan internet yang tidak stabil untuk tidak mengikuti perkuliahan atau tidak mengerjakan tugas yang diberikan karena kurang paham dengan materi yang disampaikan secara online. Mahasiswa berpikir dengan pembelajaran metode daring dosen banyak memberikan dispensasi karena mahasiswa masih belum mampu menyesuaikan diri dengan metode pembelajaran yang masih terbilang baru diterapkan, mahasiswa berpikir bisa dengan mudah mendapatkan nilai yang bagus tanpa perlu belajar dengan benar, dengan mengandalkan kalimat "maaf pak/bu, jaringan di rumah saya lemot." Hal tersebut ampuh bagi beberapa dosen yang iba, dengan memberikan toleransi keterlambatan waktu untuk mengumpulkan tugas.

\section{Upaya Mengatasi Miskonsepsi Belajar Akuntansi}

Pada masa pembelajaran tatap muka terbatas, dosen diharuskan memiliki sikap kreatif dalam menyampaikan materi. Terlebih, selama masa pandemi, mahasiswa sudah mulai nyaman belajar secara on-line, mahasiswa serasa kembali beradaptasi, dari nyamannya belajar dari atas tempat tidur tanpa mandi, kemudian kembali lagi belajar di ruang kelas. Sebagai pengajar, kita harus bisa membujuk mahasiswa untuk bisa kembali berpikir kritis. Atas adaptasi cara belajar ini, terdapat miskonsepsi bagi beberapa 
mahasiswa, untuk itu beberapa upaya mengatasi miskonsepsi dalam belajar akuntansi sebagai berikut:

1. Dosen mempersiapkan bahan ajar dan diri secara matang sebelum perkuliahan dimulai. Jangan mengabaikan persiapan, persiapan berperan penting dalam suksesnya mahasiswa mengerti materi akuntansi.

2. Membuat buku saku istilah akuntansi. Menjelaskan setiap sinonim dari akun atau istilah dalam akuntansi, contoh:

a. Aktiva merupakan kekayaan (harta) yang dimiliki perusahaan, aktiva merupakan sumber daya (reesources) bagi perusahaan untuk melakukan usaha (Soemarso, 2009). Aktiva disebut juga denga aset dan istilah dalam Bahasa Inggrisnya assets.

b. Kewajiban berisikan akun-akun seluruh utang perusahaan. Kewajiban disebut juga dengan liabilitas (liability).

c. Modal merupakan sumber pembelanjaan perusahaan yang berasal dari pemilik (Soemarso, 2009). Modal disebut juga dengan ekuitas (equity).

Dan seterusnya.

3. Membuat pembelajaran dengan menggunakan setting pembelajaran group investigation. Tipe pembelajaran ini menekankan pada kualitas dari keaktifan mahasiswa dalam membangun pengetahuannya. Suatu proses aktif dimana terjadi interaksi dengan lingkungannya dan menstranformasinya ke dalam pikirannya dengan 
bantuan strukrur kognitif yang telah ada dalam pikirannya. Pembelajaran akuntansi penuh dengan konsep-konsep yang harus dipahami oleh mahasiswa secara utuh sejak dini. Pemahaman terhadap konsep-konsep merupakan dasar untuk mengubah miskonsepsi, disamping itu juga merupakan landasan dalam pencapaian hasil belajar (Suandi, 2013).

4. Membuat suasana di kelas lebih hidup, salah satunya dengan cara belajar melalui suatu kasus akuntansi. Misal untuk pengantar akuntansi, tunjuk satu mahasiswa sebagai owner perusahaan start-up, kemudian tunjuk mahasiswa yang lain berperan sebagai perusahaan saingan, konsumen, supplier, dan lain sebagainya. Biarkan para mahasiswa tersebut menyebutkan berapa nominal harga-harga yang terkait, dari transaksi yang terjadi ini, barulah dosen mengarahkan bagaimana cara menjurnal transaksi sampai menghasilkan laporan keuangan.

5. Membuat materi dalam power point dengan tampilan yang bervariasi disertakan dengan audio (rekaman suara) dari dosen, sehingga ketika mahasiswa membaca materi bisa sekaligus mendengar penjelasan dari dosen melalui audio per slide power point. Memasukkan audio penjelasan lebih efisien dari pada video, karena video akan membuat ukuran file power point menjadi sangat besar, bisa mencapai $250 \mathrm{MB}$ dan nantinya dosen akan mengalami kesulitan pendistribusian materi karena file yang bisa diunggah pada whatsapp max. $25 \mathrm{MB}$, untuk edlink atau pun siakad terbatas dikisaran 2 MB saja. 
6. Memanfaatkan fasilitas internet, menurut Putra (2019) hasil belajar siswa mengalami peningkatan eetelah diterapkannya penerapan media internet dalam pembelajaran. Jadi upaya terakhir dalam mengatasi miskonsepsi belajar akuntansi yaitu, dosen dapat membuat video penjelasan materi dan diunggah ke channel youtube dosen pengampu, sehingga mahasiswa yang kurang memahami materi di dalam kelas dan tidak sempat bertanya dikarenakan adanya keterbatasan waktu, maka mahasiswa tersebut bisa memahami kembali materi yang disampaikan melalui video pembelajaran.

\section{Penutup}

Untuk meningkatkan keberhasilan penyerapan materi akuntansi pada mahasiswa, mahasiswa diajak untuk ikut memberikan pendapat bagaimana cara mudah mereka memahami materi, dosen mengikuti gaya belajar dari masing-masing kelas. Mahasiswa yang diajak merumuskan kontrak perkuliahan bersama, akan lebih antusias dalam mematuhi aturan karena mereka ikut bertanggung jawab atas usulannya. Kemudian dosen tidak boleh menganggap jika semua mahasiswa memiliki kecepatan dan tingkat pemahaman yang sama, oleh karena itu dosen dalam mengajar harus fleksibel dan memfasilitasi ilmu yang dibutuhkan oleh mahasiswa dengan cara-cara yang baru.

\section{Daftar Pustaka}

Putra, P. K. K. (2019). Penerapan Media Internet Untuk Mendukung Pembelajaran Pada Mata Pelajaran Etika Profesi Kelas X Akuntansi Di Smk Negeri 1 Singaraja. Jurnal Pendidikan Ekonomi Undiksha, 10(2), 480-489. 
Soemarso, S. R. (2009). Akuntansi suatu pengantar, edisi kelima. Jakarta: Salemba Empat.

Suandi, I Ketut, Ni Nyoman Aryaningsih. (2013). Implementasi Tipe Pembelajaran Group Investigasi dan Pengetahuan Awal dalam Merubah Miskonsepsi Mahasiswa dalam Pembelajaran Akuntansi. Prosiding Simposium Nasional Akuntansi Vokasi ke-2: Politeknik Negeri Bali, 17 - 18 Mei.

Yuniarti, S., \& Ulfah, M. (2013). Miskonsepsi Siswa dalam Pencatatan Jurnal Penyesuaian Perusahaan Jasa Kelas X Akuntansi 1 SMKN 3. Jurnal Pendidikan dan Pembelajaran Khatulistiwa, 2(12). 
Menyongsong PTMT Pada Dunia Pendidikan 


\title{
PENTINGNYA PEMBELAJARAN BERWIRAUSAHA PASCA PANDEMI
}

\author{
Diah Lukitasari, S.E., M.M16 \\ Universitas Pendidikan Mandalika
}

"Pembelajaran berwirausaha dapat diterapkan pasca pandemi melalui kegiatan pelatihan, asas kewirausahaan dan pembelajaran berbasis produk dengan tujuan untuk meningkatkan pengetahuan dan keterampilan siswa"

$\mathrm{M}$ asa pandemi covid-19 menuntut manusia agar bisa beradaptasi dan menata kembali kehidupan yang new normal. Tantangan dan kendala cukup dirasakan terutama di dunia pendidikan. Akibatnya muncul kebijakan-kebijakan baru dari Menteri Pendidikan terkait proses pembelajaran harus dilakukan secara jarak jauh atau secara daring/online. Keputusan untuk menerapkan pembelajaran secara online membutuhkan kesiapan yang matang bagi berbagai pihak diantaranya satuan pendidikan, guru, siswa dan orang tua sebagai wali murid. Dalam mempersiapkan pembelajaran jarak jauh/online siswa membutuhkan kuota data dan akses internet yang terjangkau. Di lain pihak, sekolah tidak memfasilitasi guru dan siswa untuk mendapatkan kuota internet secara gratis dan hanya

16Penulis lahir di Semarang, 11 Juni 1970, penulis merupakan Dosen di Universitas Pendidikan Mandalika dalam bidang Manajemen, penulis menyelesaikan gelar Sarjana Ekonomi di Universitas Diponegoro (1998), sedangkan gelar Magister Manajemen diselesaikan di Universitas Mataram pada Program Studi Ilmu Manajemen (2013). 
mengandalkan kuota internet pribadi. Akibatnya proses pembelajaran jarak jauh/online tatap muka dibatasi dan sisanya mengandalkan belajar mandiri dari rumah dengan pantauan orangtua siswa masing-masing.

Pembelajaran secara jarak jauh/online memberikan peluang dan kesempatan bagi siswa untuk belajar berbagai hal, salah satunya adalah berwirausaha. Wirausaha merupakan kegiatan usaha untuk menghasilkan nilai ekonomis bagi diri sendiri maupun orang lain. Kegiatan wirausaha mampu menciptakan ide-ide baru yang kreatif dan inovatif dalam menghasilkan suatu produk yang memiliki nilai jual dan nilai tambah. Hal ini diperkuat oleh Dewi \& Mashami (2019) bahwa kegiatan wirausaha dapat dilakukan melalui pembelajaran berbasis kewirausahaan. Pembelajaran berwirausaha dapat menumbuhkan minat dan motivasi siswa untuk menghasilkan produk yang memiliki nilai jual (Dewi, 2019). Pembelajaran berwirausaha dapat memberikan kesempatan bagi siswa untuk berkreativitas dalam menghasilkan suatu produk baru (Dewi etal., 2018; Katamsih etal., 2016; Marwah etal., 2016).

Pada proses pembelajaran berlangsung guru berperan dalam memfasilitasi siswa untuk menumbuhkan minat wirausaha sedini mungkin agar tercapai perkembangan diri yang optimal. Dalam hal ini, peran guru sangat penting untuk mengarahkan dan membimbing siswa agar menekuni dunia usaha sebagai bekal awal menjadi seorang entrepreneur. Agar menjadi entrepreneur yang handal, tentunya dibutuhkan pengetahuan dan keterampilan dalam berwirausaha. Untuk mendapatkan pengetahuan dan keterampilan berwirausaha harus ditumbuhkan melalui 
kegiatan-kegiatan pembelajaran yang berbasis wirausaha diantaranya:

\section{Melalui Kegiatan Pelatihan}

Pembelajaran berwirausaha dapat dilaksanakan melalui kegiatan pelatihan misalnya, pembuatan mie kangkung dengan berbagai tahapan yakni diawali dengan proses pembekalan pengetahuan melalui kegiatan sosialisasi atau webinar untuk mengubah pola pikir siswa. Pada tahap selanjutnya, dilakukan praktek secara langsung untuk memberikan pemahaman kepada siswa terkait proses pembuatan mie kangkung (Dewi etal., 2021). Dengan kegiatan pelatihan ini, akan dapat memberikan pembelajaran bagi siswa dalam menumbuhkan minat berwirausaha.

\section{Melalui Asas Kewirausahaan}

Dalam menerapkan pembelajaran berwirausaha harus memahami asas-asas dalam kewirausahaan yakni sebagai berikut:

a. Memiliki kemampuan menciptkan sesuatu yang baru/ide baru yang menghasilkan suatu karya berlandaskan pada etika berbisnis yang sehat.

b. Memiliki kemampuan kerja yang tekun, teliti dan produktif.

c. Memiliki kemampuan dalam menyelesaikan masalah dan menentukan keputusan secara terstruktur dan terorganisasi khususnya dalam mengambil resiko terbesar dalam berbisnis.

d. Memiliki kemampuan untuk berkarya dengan penuh semangat dan kemandirian yang tinggi. 
e. Mempunyai kemampuan dalam berpikir dan bertindak secara kreatif dan inovatif.

\section{Melalui Pembelajaran Berbasis Produk}

Pembelajaran berbasis produk merupakan model pembelajaran yang menghubungkan antara pengetahuan dengan keterampilan dalam kegiatan eksperimen atau percobaan. Kombinasi antara pengetahuan dan keterampilan ini bertujuan untuk menghasilkan suatu produk yang memiliki nilai jual. Dalam hal ini, pengetahuan dan keterampilan bisa dijadikan sebagai modal usaha untuk membuka lapangan pekerjaan. Tentunya pembelajaran berbasis produk menekankan pada proses pembelajaran yang aktif, kreatif, inovatif dan mampu berkomunikasi dan berinteraksi sosial yang baik (Dewi \& Kurniasih, 2017). Keberhasilan dalam menerapkan pembelajaran berbasis produk dipengaruhi oleh faktor pendukung yaitu: a) Fasilitas yang terstandarisasi, b) Pendidik atau instruktur yang bersertifikat, c) Pengalaman tambahan untuk menjamin kesiapan kerja, d) Penghargaan terhadap kepuasan konsumen, e) Komitmen untuk menjaga kualitas. Sedangkan faktor lain yang mempengaruhi meliputi: a) Kompetensi dosen/instruktur, b) Kesiapan peserta didik, c) Tersedianya peralatan dan bahan yang sesuai dengan kebutuhan, dan d) Modal yang cukup besar.

Dengan demikian, dapat disimpulkan bahwa pembelajaran berwirausaha dapat diterapkan pasca pandemi melalui kegiatan pelatihan, asas kewirausahaan dan pembelajaran berbasis produk dengan tujuan untuk meningkatkan pengetahuan dan keterampilan siswa. Implikasi dari pentingnya 
pembelajaran berwirausaha pasca pandemi yakni a) dapat menciptakan lapangan pekerjaan baru sehingga meminimalisir penggangguran yang ada, b) mendukung pergerakan pembangunn di lingkungan sekitar, c) dapat menciptakan pribadi yang mandiri, disiplin, jujur, tekun dan bertanggungjawab, c) menjadi contoh bagi orang lain dalam hal bekerja keras, d) pantang menyerah, e) memprioritaskan efisiensi dari hasil kerja.

\section{Daftar Pustaka}

Dewi, C. A., \& Mashami, R. A. (2019). The effect of chemoentrepreneurship oriented inquiry module on improving students' creative thinking ability.Journal of Turkish Science Education, 16(2), 253-263.

Dewi, C. A. (2019). Improving creativity of prospective chemistry teacher through chemoentrepreneurship oriented inquiry module on colloid topics. In Journal of Physics: Conference Series (Vol. 1156, No. 1, p. 012017). IOP Publishing.

Dewi, C. A., Anggriani, M., \& Pahriah, P. (2018, September). Pengembangan Perangkat Pembelajaran CTL Berbasis Entrepreneurship untuk Meningkatkan Motivasi Belajar Siswa pada Materi Minyak Bumi. In Prosiding Seminar Nasional Lembaga Penelitian dan Pendidikan (LPP) Mandala (pp. 129-141).

Dewi, C. A., \& Kurniasih, Y. (2017). Pemberdayaan petani jagung melalui pengembangan usaha diversifikasi produk olahan jagung di Labuapi Kabupaten Lombok Barat. Lumbung Inovasi: Jurnal Pengabdian kepada Masyarakat, 2(1), 1-6.

Dewi, C. A., Kurniasih, Y., Lukitasari, D., \& Sakban, A. (2021). Pelatihan Pembuatan "MIKUNG"(Mie Kangkung) Untuk Petani Kangkung di Kecamatan Lingsar Lombok Barat. Jurnal Lentera Widya, 2(2), 12-18. 
Katamsih, D. U., Dewi, C. A., \& Pahriah, P. (2016). Penerapan Model Learning Together (LT) Berbasis Entrepreneurship Terhadap Minat Wirausaha dan Hasil Belajar Siswa. Hydrogen: Jurnal Kependidikan Kimia, 4(1), 11-16.

Marwah, M., Dewi, C. A., \& Mashami, R. A. (2016). Pengaruh Pembelajaran Kooperatif Tipe TAI Berbasis Chemoentrepreneurship Terhadap Motivasi Berwirausaha dan Penguasaan Konsep Siswa Pada materi Koloid. Hydrogen: Jurnal Kependidikan Kimia , 4(2), 80-86. 


\title{
PEMBIASAAN KEBIJAKAN PEMKAB BANDUNG BAGI UKM COFFE SHOP MASA PANDEMI HINGGA KINI
}

\author{
Lathifaturahmah 17 \\ STKIP Pangeran Dharma Kusuma
}

"Skema pembiayaan, pinjaman kewirausahaan, pelatihan staf terampil, transformasi teknologi digital, peningkatan likuiditas dengan lebih banyak pinjaman jangka pendek dan perencanaan proaktif untuk masa depan"

\section{Pendahuluan}

Dewasa ini, Ekonomi global telah dipengaruhi oleh beberapa resesi pada akhir abad ini karena adanya perubahan mendadak dalam harga minyak, kebijakan dan keuangan. Namun, gelombang pandemi covid-19 telah membawa dampak besar pada kesehatan dan ekonomi, maupun dalam hal investasi, perdagangan dan pariwisata (Gösslingetal.,2020). Penerapan social distancing telah membuat semua orang sangat berhati-hati dalam melakukan aktivitas terbatas di luar rumah. Hal ini berdampak pada berbagai sektor bisnis yang ada.

17Lathifaturahmah lahir di Cirebon 06 April 1995, latar belakang pendidikan S1 Ilmu Hukum di STAIMA Cirebon, lulus tahun 2016, S2 di Universitas Pasundan Bandung Fakultas Manajemen Bisnis Konsentrasi Sumber Daya Manusia lulus tahun 2020. Memulai karir mengajar tahun 2021 dan saat ini dosen Program Studi Pendidikan Ekonomi di STKIP Pangeran Dharma Kusuma Indramayu. 
Peran di perusahaan besar dan kecil telah mendorong pertumbuhan ekonomi. Namun, sejak adanya pandemi covid-19 bisnis menjadi rentan, karena perusahaan sangat tergantung pada kecepatan perputaran uang dari penjualan produknya. Oleh karena itu, penurunan permintaan konsumen telah mengurangi aliran arus kas perusahaan (Priyono et, al.,2020).

Pemerintah telah menerapkan kebijakan physical distancing, social distancing, perjalanan terbatas dan pemberlakuan pembatasan kegiatan masyarakat (PPKM), dengan demikian, berbagai bisnis telah terpengaruh termasuk pusat perbelanjaan, restoran, dan pasar (Chettyetal., 2020). Konsumen di berbagai daerah telah mengubah kebiasaan cara belanja mereka dan memenuhi kebutuhan belanja mereka secara online (Bartiketal., 2020a, 2020b). Pemerintah telah mengeluarkan kebijakan public, pemberlakuan pembatasan kegiatan masyarakat (PPKM) pertama kali berlaku di 11 Januari sampai 25 januari 2021 termasuk di daerah kabupaten bandung dan 23 kabupaten atau kota pada enam provinsi yang memiliki resiko covid-19 yang tinggi, sebelumnya, terdapat sebutan lain yang diperkenalkan pemerintah pada awal pandemi covid-19 yaitu PSBB dan PPKM mikro, aturan tersebut diberlakukan pada tanggal 17 bulan April tahun 2020, kemudian pemerintah memberlakukan istilah baru untuk menekan penyebaran covid-19 pada daerah yang beresiko tinggi dengan nama PPKM.

Covid-19 telah menghambat perekonomian dan pertumbuhan di seluruh dunia dengan sangat cepat dan luas. Menurut laporan bank dunia kemunculan tiba-tiba covid-19 telah membawa tren resesi pada ekonomi global dengan tidak ada satu negara yang dapat bertahan terhadap 
dampak buruk covid-19. Secara keseluruhan, 5,2\% mengalami penyusutan di tahun 2020 dilaporkan oleh bank dunia. Hal ini menunjukkan perusahaan kecil dan menengah sebagai korban pandemic covid-19 ini dan memiliki implikasi yang parah bagi bisnis untuk periode jangka panjang. Fakta-fakta tersebut jelas menunjukkan dampak covid-19 dapat terjadi pada usaha kecil dan menengah.

Covid-19 telah melemahkan kesehatan manusia dan perekonomian global. Hal ini dapat dilihat pada pengurangan konsumsi di berbagai barang dan jasa, seperti kenaikan biaya operasional bisnis, dan gangguan pasokan tenaga kerja. Secara khusus, pandemi covid-19 telah mengganggu konstruksi alur kerja industri dan rantai pasokan, dampak lainnya mencakup penutupan tempat kerja, pembatasan perjalanan, produktivitas rendah, kehilangan pekerjaan, kecemasan pekerja dan kesulitan, kenaikan anggaran manajemen dan biaya operasi yang tinggi (Al Amri dan Marey Perez, 2020)

WHO dan ILO (2020) mengeluarkan panduan mengenai langkah-langkah kesehatan dan keselamatan kerja untuk menangani pandemi covid-19 di dunia. Pelaku bisnis yang ada telah mengubah cara untuk memenuhi tuntutan baru pada era pandemic covid-19 melalui adaptasi pengaturan kerja, penerapan perencanaan kerja, bahkan pekerjaan di lakukan secara virtual, serta manajemen stres dan risiko psikososial lainnya (Ogunnusi dkk., 2020).

Lebih lanjut di Indonesia, pihak berwenang mengakui kebutuhan mendesak untuk melindungi kesehatan dan kesejahteraan pekerja pada lokasi bisnis dalam menghadapi penyebaran serta peningkatan jumlah kasus covid-19 di negara ini. Oleh karena itu, Peraturan yang telah dibuat mengintruksikan untuk penggunaan masker wajah di 
tempat kerja, pembatasan berkerumun, diwajibkan jarak minimal $1 \mathrm{M}$ antara pekerja, membatasi lebih dari 50 orang di ruang tertutup, perizinan akses hanya ke personel penting di tempat dan melarang pekerja pada suhu tubuh diatas 38 derajat celcius masuk di lokasi.

\section{Pembahasan}

Perusahaan yang bergantung terhadap ruang fisik, seperti restoran, supermarket, kebugaran, pusat perbelanjaan, pasar makanan tradisional, bioskop dan dealer mobil, semuanya mengalami kerugian. Hal ini adalah kebalikan dari pasar online, disaat pandemic covid-19 seperti lockdown covid-19, penggunaan teknologi adalah solusi terbaik untuk menjaga kelangsungan bisnis (Fletcher dan Griffiths, 2020).

Perusahaan besar maupun kecil adalah bagian dari sistem ekonomi, adopsi teknologi digital sangat penting untuk mencapai keberlanjutan bisnis baik sekarang maupun di masa depan (Ameen, et.al.,2021). Pada beberapa perusahaan, terutama pada usaha kecil, tidak memiliki pengetahuan yang cukup tentang keterampilan digital untuk menjalankan bisnis mereka secara online sehingga situasi ini memaksa mereka untuk mempelajari dan menggunakan alat bisnis online (Antonescu, 2020). Namun, konsumen dapat melanjutkan hidup mereka dengan penggunaan teknologi digital yang telah disediakan oleh layanan seperti Amazon, Google, Cloud, layanan Web, Microsoft, Azure, dan dengan bantuan aplikasi seperti Zoom, Netflix, dan Slack (Javaid et al., 2020).

Pada masa Pemberlakuan Pembatasan Kegiatan Masyarakat (PPKM) covid-19 seharusnya tidak menjadi penghalang bagi perusahaan untuk meningkatkan penjualannya karena perusahaan dapat mengadopsi 
teknologi baru untuk mempromosikan produk dan layanan mereka melalui saluran digital online (Doyle dan Conboy, 2020). Strategi teknologi digital mengharuskan mengubah toko offline perusahaan menjadi online, untuk keselamatan konsumen dan demi berjalnnya bisnis serta kenyamanan selama pandemi covid-19, perusahaan dapat meningkatkan promosi mereka melalui aplikasi online untuk penjualan dan pengiriman (Chetty, et.al., 2020).

Pemberlakuan Pembatasan Kegiatan Masyarakat (PPKM) covid-19 ternyata menjadi peluang yang tepat bagi perusahaan untuk lebih fleksibel dan dapat menyesuaikan dalam berbagai situasi yang berbeda. Hal ini telah mendorong mereka untuk mengembangkan strategi yang berbeda untuk menyediakan barang dan jasa berdasarkan kebutuhan konsumen maupun bisnis mereka (Chetty et.al., 2020).

Pelaku usaha sektor UMKM, khususnya sektor coffe shop pada kabupaten bandung, ikut merasakan dampak berat terkena pandemi covid-19, pada pemberlakukan pembatasan kegiatan masyarakat yang telah di berlakukan oleh pemerintah, sektor coffe shop sangat terdampak setelah Pemberlakuan Pembatasan Kegiatan Masyarakat (PPKM) karena warga harus menghindari kerumunan, semua transaksi pembelian terutama dalam hal kuliner makanan harus take away, mulai dari distribusi supply and demand terhambat, serta penjualan biji kopi maupun pemasaran kopi melalui penggunaan media cangkir.

Pandemi covid-19 telah menjadi ujian berat bagi seluruh pengelola bisnis coffe shop yang ada, pada awal bulan merebaknya covid-19, sudah banyak pelaku bisnis yang telah terganggu agenda jual beli dan promosinya, bahkan tak sedikit toko yang harus tutup karena tidak bisa 
menutup biaya produksi yang harus ditanggung. Delapan bulan setelah kasus pertama Covid-19 ditemukan di Indonesia, pandemi masih jauh dari kata selesai, pihakpihak terdampak harus bisa bertahan dengan caranya masing-masing untuk menghadapi tantangan tersebut. Hal ini sangat dirasakan oleh semua pelaku bisnis coffe shop yang ada di kabupaten bandung, coffe shop harus terus berinovasi untuk bertahan ditengah pandemi.

\section{Simpulan}

Penekanan dari penulisan ini adalah pada analisis sektor coffe shop di kabupaten bandung, stabilitas ekonomi keluarga pada kalangan masyarakat menengah kebawah selama pemberlakuan pembatasan kegiatan masyarakat. Berawal pada bukti dokumenter dan terkait literatur secara kolektif, dieksplorasi untuk mengidentifikasi konsekuensi yang dihadapi UKM terhadap lonjakan Covid-19. Usaha Kecil dan menengah telah mengalami masalah seperti kekurangan barang, transportasi, penurunan permintaan produk dan jasa, penurunan laba dan penjualan, operasi terbatas, pembatasan kegiatan dan PHK karyawan.

Temuan pada penelitian ini diikuti dengan rekomendasi sebagai langkah kebijakan untuk pemerintah dan manajemen UKM. Langkah-langkah yang disebutkan sebagai rekomendasi adalah implikasi praktis dari penelitian ini bagi para pemangku kepentingan. Skema pembiayaan, pinjaman kewirausahaan, pelatihan staf terampil, transformasi teknologi digital, peningkatan likuiditas dengan lebih banyak pinjaman jangka pendek dan perencanaan proaktif untuk masa depan.

Diharapkan dengan adanya penelitian ini, para akademisi memiliki lebih banyak bukti tentang subjek dan selanjutnya dapat memperluas penelitian di berbagai sektor 
di kabupaten Bandung. Penelitian ini memperkaya literatur yang berkaitan dengan dampak pandemi pada usaha kecil dan menengah dan terbukanya jalan untuk penelitian di masa yang akan datang.

\section{Datar Pustaka}

Al Amri,T.and Marey-Perez, M. (2020),"ImpactofCovid19onOman'sconstruction industry", Technium Social Sciences Journal, Vol.9No.1,pp.661-670.

Ameen, N., Tarhini, A., Reppel, A. and Anand, A. (2021), "Customer experiences in the age of artificial intelligence", Computers in Human Behavior, Vol.114, p. 106548.

Antonescu, D. (2020), "Supporting small and medium-size enterprises through the Covid-19 crisis in Romania", Central European Journal of Geography and Sustainable Development, Vol.2No.1, pp.38-57.

Bartik, A.W., Bertrand, M., Cullen, Z.B., Glaeser, E.L., Luca, M. and Stanton, C.T. (2020a), HowAre Small Businesses Adjusting to Covid-19? Early Evidence from a Survey (No. w26989), National Bureau of Economic Research.

Chetty, R., Friedman, J.N., Hendren, N., and Stepner, M. (2020), "Real-time economics: a new platform to track the impacts of Covid-19 on people, businesses, and communities using private sector data", NBER Working Paper, Vol.27431.

Chetty, R., Friedman, J.N., Hendren, N., and Stepner, M. (2020), "Real-time economics: a new platform to track the impacts of Covid-19 on people, businesses, and communities using private sector data", NBER Working Paper, Vol.27431.

Doyle, R. and Conboy, K. (2020), "The role of is in the covid-19 pandemic: a liquid-modern perspective", International Journal of Information Management, Vol.55, p.102184.

Fernandes, N. (2020), "Economic effects of coronavirus outbreak (Covid-19) on the world economy", Available at SSRN3557504. 
Fletcher, G. and Griffiths, M. (2020), "Digital transformation during a lockdown", International Journal of Information Management, Vol.55, p.102185

Gössling, S., Scott, D. and Hall, C.M. (2020), "Pandemics, tourism and global change: a rapid assessment of Covid-19", Journal of Sustainable Tourism, pp.1-20.

Javaid, M., Haleem, A., Vaishya, R., Bahl, S., Suman, R. and Vaish, A. (2020), "Industry 4.0 technologies and the applications in fighting Covid-19 pandemic", Diabetes and Metabolic Syndrome: Clinical Research and Reviews, Vol.14No.4, pp.419-422.

McKibbin, W.J.and Fernando, R.(2020), The Global Macroeconomic Impacts of COVID-19: Seven Scenarios, Asian Economic Papers, MIT Press, pp.1-55.

Ogunnusi, M., Hamma-Adama, M., Salman, H. and Kouider, T. (2020), "COVID-19 pandemic: the effects and prospects in the construction industry", International Journal of Reconfigurable and Embedded Systems, Vol.14 No. Special Issue2, pp.120-128

Priyono, A., Moin, A. and Putri, V.N.A.O. (2020), "Identifying digital transformation paths in the business model of SMEs during the Covid-19 pandemic", Journal of Open Innovation: Technology, Market, and Complexity, Vol.6No.4, p.104. 


\section{MANAJEMEN PENGEMBANGAN PARIWISATA DAN EKONOMI KREATIF WARUNG KOPI DI MASA PANDEMI}

\section{Amik Nadziroh, M.Pd 18 \\ UIN Sayyid Ali Rahmatullah Tulungagung}

"Dunia pariwisata dan ekoniomi kreatif warung kopi dimana dengan turut menghadirkan pemandangan alam dan biuatan yang dapat menjadi brand, daya tarik bagi konsumen"

Coronavirus Diseanse (Covid-19) menimbulkan banyak
permasalahan seperti; pada sektor pariwisata dan ekonomi. Ditambah pula dengan Peraturan Mentri Hukum dan HAM Nomor 11 Tahun 2020 tentang larangan warga negara asing (WNA) masuk ke Indonesia, sebagai upaya mengantisipasi penyebaran virus Covid-19. Situasi ini mengakibatkan keberadaan pelaku usaha pariwisata dan ekonomi menurun yang seharusnya mendapatkan perhatian khusus karena merupakan penggerak utama perekonomian bangsa dan turut menyumbang PDB terbesar negara.

Pasca terpuruk akibat adanya pandemic Covid-19, kegiatan perekomian terus menupayakan, membangun,

18Penulis lahir di Tulungagung, 04 April 1994, penulis merupakan mahasiswa Pascasarjana program Doktoral prodi Manajemen Penidikan Islam di UIN Sayyid Ali Rahmatullah Tulungagung dan pendiri serta ketua TPQ Sulaiman Desa Tenggong Kecmatan Rejotangan Kabupaten Tulungagung. Penulis menyelesaikan pendidikan S1 dengan prodi Pendidikan Guru Madrasah Ibtidaiyah di STAI Diponegoro Tulungagung dan melanjutkan S2 dengan prodi yang sama di IAIN Tulungagung. 
mengembangkan, dan membuka peluang baru bagi pelaku pariwisata dan ekonomi kreatif tanah air salah satunya usaha pariwisata dan ekonomi kreatif warung kopi dengan menyediakan nuansa alam di sekelilingnya. Hal tersebut menjadi salah satu kekuatan baru bagi sektor pariwisata dan ekonomi kreatif, yang nantinya setelah pandemi berakhir kemampuan menguasai pasar dan lebih mencintai produk lokal atau dalam negeri.

Meninjau dari program keberhasilan usaha warung kopi dengan mengedepankan pariwisata dan ekonomi kreatif bernuansa alam nusantara dengan harapan adanya Pemulihan Ekonomi Nasional. Bahu menbahu dalam menciptakan inovasi dan kreasi mewujudkan target pemerintah. Pasalnya, inovasi yang diterapakan merupakan napad dari keberlangsungan pariwisata dan ekonomi kreatif khususnya warung kopi. Jika inovasi dan kreativitas dapat berjalan beriringan, maka tujuan dari pemulihan khususnya bidang pariwisata dan ekonomi kreatif akan semakin mudah terwujud.

Sebagai upaya pengelolaan manajemen yang diterapkan pada sektor pariwisata dan ekonomi kreatif warung kopi masa pandemi ialah: Pertama, adanya pendampingan dimana program tersebut sebagai pengelolaan kemandirian yang diunjukkan oleh pelaku ekonomi dalam kelompok sasaran warung kopi pasca keberlakuan PPKM, hal ini dilakukan karena adanya kemitraan yang terbangun secara alami dari masing-masing kelompok sasaran di satu lokasi pariwisata dengan banyak pelaku ekonomi kreatif didalamnya. Dengan demikian dapat dikatakan bahwasanya interaksi yang terjadi antar anggota kelompok pelaku ekonomi kreatif muncul secara 
alami dengan budaya tolong menolong, gotong royong, dan sebagainya.

Kedua, Marketing Strategy diterapkan atas dasar tindakan yang mengarah pada kegiatan pemasaran dengan kondisi persaingan dan lingkungan yang bisa saja berubah. Penerapan yang diterapkan sebelum adanya strategy pemasaran ialah mempelajari kondisi pasar dan menilai posisi pasar agar dapat lebih mudah menentukan kegiatan pemasaran. Berikut beberapa strategy yang dapat di terapkan; a) Segmentation tindakan yang diterapkan dengan mengidentifikasi konsumen secara terpisah serta memperhatikan karakteristik kebutuhan produk dan bauran pemasaran. b) Targeting yang merupakan tindakan memilih satu atau lebih segmen pasar dengan memperhatikan tingkat permintaan, daya tarik, dan sasaran. c) Positioning dengan mempertimbangkan posisi usaha dalam artian pasar atas dasar atribut seperti kualitas dan harga menurut kelas pengguna atau pun produk

Ketiga, Marketing Tactic sebuah strategy untuk meningkatkan produk(pariwisata dan ekonomi kreatif warung kopi) agar dapat dinikmati dan niminati oleh konsumen mencpai winning market share dengan bebepa strategi diantaranya: a) product Differentiation proses dimana membuat produk lebih menarik dengan cara pembedaan yang dilakukan baik terhadap produk competitor maupun produk sendiri. b) $7 P$ ialah strategi yang diterapjan menggunakan konsep 7P (products, promotions, place, people, proces, and physica; evidence. c) personal Selling, andanya komunikasi perorangan antara penjual dan pembeli dengan memperkenalkan produk unggulan. 
Keempat, Marketing Value adanya pradigma pemasaran yang dapat dibangun melalui: a) Brand, merek, nama, desain yang membuatnya dapat diingat oleh masyarakat luas atau pasar. b) Service, pemberian pelayanan sebgai wujud perbuatan dengan memberikan kepuasan kepada konsumen. c) Process, menyangkut adanya kemampuan mengolah dan mendistribusikan kebutuhan konsumen.

Semua proses tersebut akan dikemas dalam dunia pariwisata dan ekoniomi kreatif warung kopi dimana dengan turut menghadirkan pemandangan alam dan biuatan yang dapat menjadi brand, daya tarik bagi konsumen dengan tetap mengintensifkan informasi dan kreativitas dengan mengandalkan ide menarik dan wahanawahana baru di lingkungan ekonomi kreatif seperti: kegiatan promosi, pelayanan prima, pembangunan wahana baru, spot foto baru, dan sebaginya.

\section{Daftar Pustaka}

Muchfudz, Msyhuri. 2021. Kemandirian Pelaku Ekonomi Kreatif Berbasis Singkong Pasca Program Stimulan Dana melalui TRansaksi Qordhul-Hasan Dimasa Pandemi. Jurnal Aplikasi dan Inovasi Ipteks SOLIDITAS. Nov 4;2: 155-160. Doi: 10.31328/js.v4i2.2722

Siagian, Onny, Ade. 2021. Strategi Pemuliahan Pemasaran UMKM di Masa Pandemi Covid-19 pada Sektor Ekonomi Kreatif. Jurnal Teknologi dan Informasi Bisnis. Januari $3 ; 1(31)$ 206-217. https://doi.org/10.47233/jiteksis.v3l1.2.2 


\section{BAB III}

PENERAPAN DAN

PERMASALAHAN

SELAMA PTMT

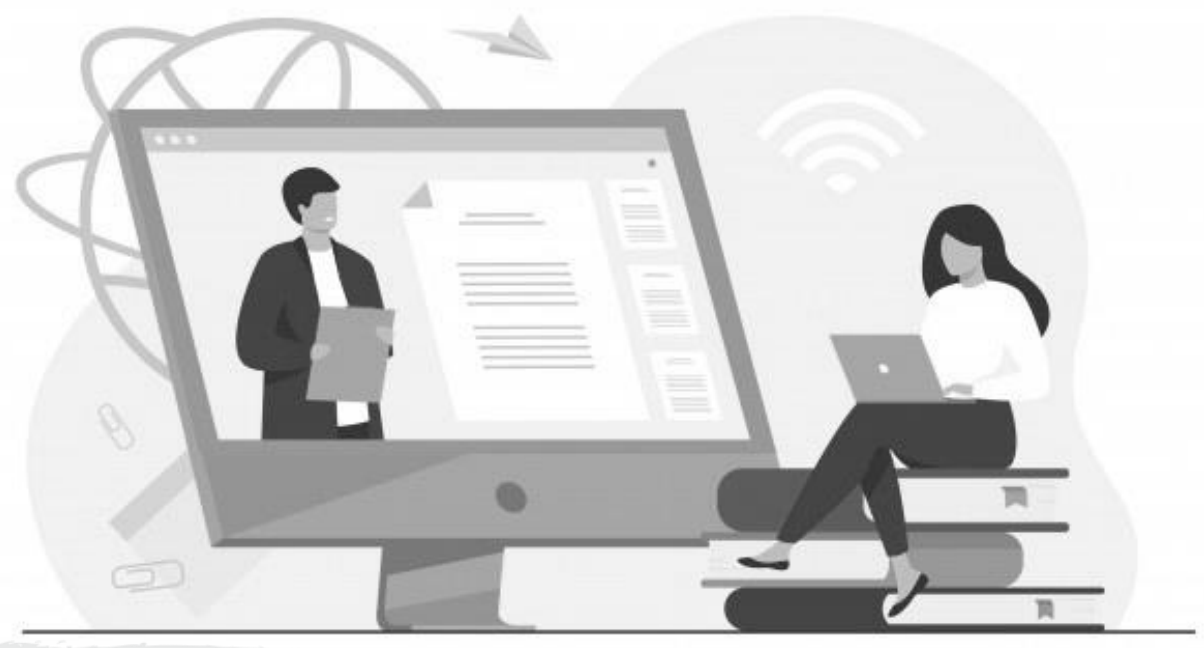


Menyongsong PTMT Pada Dunia Pendidikan 


\title{
KEKURANGAN DAN KELEBIHAN \\ PEMBELAJARAN BLENDED LEARNING \\ PASCA PANDEMI
}

\author{
Muhammad Yusuf, S.Pd.I, M.Pd 19 \\ Bosowa School Makassar/STAI DDI Makassar
}

“Blended Lerning membuat peserta didik tidak bosan atau jenuh karena adanya variasi dalam pembelajaran, sedangkan

kekurangannya durasi waktu yang masih kurang saat pelaksanaan pembelajaran sehingga belum cukup maksimal"

\section{Pengertian Pembelajaran Blended Learning}

N enurut bahasa bahwa yang dimaksud dengan Blended 1 learning adalah belended berarti perpaduan atau campran, sedangkan learning berarti pembelajaran. Selanjutnya menurut istilah bahwa Blended Learning adalah suatu system pembelajaran yang mengandung unsur penggabungan antara system yang satu dan system yang lainnya dalam proses pembelajaran. Graham mengatakan bahwa blended learning itu merupakan pengkombinasian

${ }^{19}$ Penulis Lahir di Botto Padang ( Bone, Sulawesi Selatan ) 03 Juli 1985, Penulis merupakan pengajar di Bosowa School Makassar dan Sekolah Tinggi Agama Islam (STAI ) DDI Kota Makassar dalam bidang Ilmu Pendidikan Agama Islam ( PAI ), penulis pernah belajar di Lembaga Pendidikan Islam dan Arab ( LIPAI ) tahun 2004-2008, kemudian menyelesaikan gelar Sarjana S1 tahun 2008 di Institut Agama Islam AlAqidah Jakarta dan Menyelesaikan Gelar Magester di UIN Alauddin Makassar pad tahun 2016 dengan Jurusan Pendidikan Agama Islam (PAI), sekarang penulis sedang melanjutkan kuliah pada program doctoral dengan konsentrasi Pendidikan dan Keguruan di UIN Alauddin Makassar. 
antara pembelajaran tradisionalyang biasa dilakukan oleh para praktisi pendidikan melalui penyampaian materi secara online dan offline kepada peserta didik dengan memanfaatkan media tekhnologi.

Menurut Musa blended learning adalah penggabungan pembelajaran antara pemebelajaran daring dengan pembelajran luring atau tatap muka. Dengan melakukan pembelajaran online yang memanfaatkan media internet. Blended learning ini merupakan perpaduan dari pengembangan teknologi berbasis multimedia, CD ROM, video streaming, email, voice mail dll dengan menggabungkan pembelajaran tatap muka dikelas. Pembelajaran luring memberi kesempatan kepada peserta didik untuk menanyakan hal ataupun permasalahan yang berkaitan materi yang diajarkan oleh guru.

Model pembelajaran blended learning adalah model pembelajaran tatap muka yang digabung dengan model pembelajaran online yang berbasis tekhnologi. Metode ini terkadang disalah artikan sama seperti pembelajaran online atau daring. Blended learning merupakan penyempurnah dari metode pembelajaran online yang mengharuskan peserta didik melakukan pembelajaran dengan system daring secara utuh. Melalui blended learning, pembelajaran dianggap lebih efektif dan tidak membuat bosan peserta didik karena memungkinkan peserta didik dapat berkomunikasi dengan dua arah secara langsung (live).

Adapun unsur-unsur yang perlu diperhatikan dalam modela pembelajaran blended learning adalah:

1. Tatap muka atau bertemu langsung.

Hal ini bukan menjadi sesuatu yang baru dalam system pendidikan, khususnya di Negara kita Indonesia 
tetapi system pembelajaran dengan tatap muka itu sangat efektif dilakukan dalam proses pemlejaran agar guru dan peserta didik dapat berkomunikasi dengan baik.

2. Belajar mandiri.

Peserta didik dapat belajar secara mandiri dengan menerapkan metode pembelajran blended learning, karena pembelajaran dengan metode blended learning tidak menfokuskan belajar dengan satu arah saja tetapi pembelajaran dapat dilakukan dengan berbagai metode yang dapat dilakukan oleh peserta didik.

3. Kerja sama.

Hal ini sangat penting, agar guru dan peserta didik bisa memaksimalkan waktunya dengan baik sehingga proses pembelajaran dilakukan secara online bisa maksimal. Disini guru dapat merancang dengan baik model-model pembelajaran blended learning agar kalaborasi guru dan peserta didik, peserta didik dengan teman sejawat bisa berkalaborasi dengan baik melalai tool-tool yang ada dalam alat komunikasi seperti chat room, whatshap, classroom, dan lain-lain.

4. Evaluasi.

Evaluasi dari pembelajaran blended learning perlu dilakukan untuk mengukur keefektifan dalam proses pembelajaran baik itu pembelajaran secara daring maupun secara luring sehingga pembelajaran dapat kita capai sesuai dengan tujuan yang di inginkan.

\section{Kelebihan Dan Kekurangan Pembelajaran Blended Learning Pasca Pandemi}

Wabah pandemic covid 19 telah mengubah berbagai aktifitas masyarakat termasuk dunia pendidikan, yang 
dulunya model pembelajaran dilakukan dengan tatap muka, sekarang ini berubah ke berbagai macam model pembelajaran diantaranya adalah dengan model pembelajaran blended learning.

Model pembelajaran Blended Lerning ini merupakan solusi yang bagus untuk dilakukan oleh guru dalam melakukan proses pembelajaran sehingga semua kegiatan dapat terlaksana dengan baik dan lancar. Pembelajaran Blended learning merupakan pembelajaran yang sangat efektif dan efesien dalam meningkatkan minta belajar peserta didik di lingkungan belajar yang berbeda-beda.

Pembelajaran Blended learning ini mempunyai banyak kelebihan dan kekurangan. Adapun kelebihan dari pembelajaran blended learning adalah:

1. Fleksibel

Dengan adanya pembelajaran blended learning ini yang memudahkan dalam melakukan proses pembelajaran yang memberikan solusi yang fleksibel terhadap guru dan peserta didik atau dosen dan mahasisiwa. Dengan metode ini, guru dan peserta didik atau dosen dan mahasisiwa tidak musti harus datang dikampus tiap hari. Proses pembelajaran dapat dilakukan secara online dalam kesepatan yang sudah disepakati bersama.

\section{Efesien}

Di antara kelebihan Pembelajaran blended learning lebih efesien baik dari segi biaya dan waktu. Para guru dan dosen tidak perlu lagi memiliki materi dalam bentuk dokument fisik karena sudah tersedia semua dalam sebuah data tertentu. Dari segi waktu, guru dan 
dosen dapat melakukan pembelajaran kapan dan dimana saja.

3. Interaktif

Dengan metode blended learning,materi pembelajaran bisa lebih intraktif. Sebeb peserta didik dapat menerima materi pelajaran dalam berbagai bentuk termasuk dalam bentuk video interaktif, video penjelasan-penjelasan guru atau dosen dan materimateri dari buku online (e-book).

Selanjutnya menurut Arman Saputra (Guru Bosowa School Makassar) bahwa kelebihan dari pembelajaran blended learning adalah dapat membuat peserta didik tidak bosan atau jenuh karena adanya variasi dalam pembelajaran. Begitupula menurut Rifky Wijaya (Guru bosowa School Makassar) bahwa kelebihan dari pembelajaran blended learning adalah peserta didik dapat mengenal konsep belajar yang belum pernah dilakukan sebelumnya, dapat mendorong peserta didik lebih adaptif terhadap perubahan model dalam pembelajaran, serta mengakomodasi kebutuhan peserta didik secara offline dan online.

Sedangkan kekurangan dari pembelajaran blended learning adalah:

1. Kertergantungan terhadap jaringan internet

2. Blended learning akan sulit diterapkan jika sarana dan prasarana tidak memamadai.

3. Fasilitas yang dimiliki oleh peserta didik tidak merata.

4. Jaringan internet tidak merata disemua daerah, khususnya didaerah pelosok. 
Adapun kekurangan dari model pembelajaran blended learning menurut Arman Saputra bahwa durasi waktu yang masih kurang saat pelaksanaan pembelajaran tatap muka ( offline ) sehingga materi yang disampaikan kepada peserta didik tidak terlalu maksimal. Selanjutnya menurut Rifky Wijaya bahwa kekurangan dari blended learning adalah, pertama: guru menuai kesulitan dalam mengajar jika melakukan blended learning dengan cara parallel dengan offline dalam satu waktu yang bersamaan. Kedua: guru harus mempersiapkan bahan ajar dan penilaian dalam dua model sehingga guru harus kreatif dalam membuat materi dan penilaian.

\section{Daftar Pustaka}

Graham R, Charkes, Antony G. Piccianon, Charles D, Dziuban. Blended Learning Research Perspestive.New york: Routledge, 2014

https://educhannel.id/blog/artikel/pengertian-blended-

learning.html.diakses14 November 2021.

https://blog.lintasarta.net/article/solution/smart-city/smartcampus//apa-itu-metode-pembelajaran-blended-learning diakses 14 November 2021

Rusman, dkk, Pembelajaran Berbasis Teknologi Informasi dan Komunikasi, Jakarta: PT RajaGrafindo Persada, 2011 


\title{
JOGO TONGGO: \\ ETOS KEDERMAWANAN \\ DI MASA PANDEMI
}

\section{Muhammad Julijanto, S. Ag., M. Ag. ${ }^{20}$ \\ UIN Raden Mas Said Surakarta}

"Jogo tonggo sebagai etos kedermawanan di masa pandemi menjadi solusi dalam membangun solidaritas warga"

\begin{abstract}
Dandemi Covid-19 telah merubah sikap, perlilaku, tindakan, seseorang dalam pergaulan sosial di tengah masyarakat. Kerinduan masyarakat akan berkumpul, berkerumun, bertatap muka, bersilaturrahmi saling kunjung menguji menjadi gaya hidup yang kini dibatasi. Secara psikologis manusia sebagai makhluk sosial yang senantiasa melakukan interaksi dengan sesamanya dalam kondisi suka dan duka sekalipun. Kehadiran secara fisik menjadi bukti sebuah komitmen, kemanusiaan, kebersamaan dan solidaritas.
\end{abstract}

20Penulis lahir di Banjarnegara, 15 Juli 1972, Dosen Program Studi Hukum Ekonomi Syariah Fakultas Syariah UIN Raden Mas Said Surakarta. Pendidikan dimulai dari SD Muhammadiyah I Banjarnegara 1986, MTs PPMI Assalaam Surakarta 1989, SMA PPMI Assalaam Surakarta 1992, Pendidikan sarjana ditempuh di Jurusan Peradilan Agama Fakultas Syariah IAIN Walisong Semarang di Surakarta 1997, Magister Agama ditempuh di Pascasarjana IAIN Sunan Kalijaga Yogyakarta tahun 2003 dan Pendidikan program doctor masih on going 2018 di Studi Islam Konsentrasi Ilmu Hukum dan Pranata Sosial Islam Pascasarjana UIN Sunan Kalijaga Yogyakarta. 
Kondisi yang serba dibatasi menciptakan kreativitas dan inovasi dalam berbagai bidang kehidupan. Sebuah ungkapan menyatakan setiap krisis akan menghasilkan pemenang, merekalah yang tangguh dan mampu mengerahkan segala sumber dayanya untuk mampu memenangkan persaingan dalam survival krisis yang dihadapi. Demikian juga detailnya gagasan segara dikembangkan dan pikiran kreative mendorong solusi di tengah berbagai pembatasan interaksi sosial. Interaksi berubah yang dahulunya bebasis luring jumpa fisik dan tatap muka, berinteraksi secara langsung, kini di tengah pandemi dilakukan secara daring dengan berbagai plafom aplikasi pertemanan-media sosial berbasis internet.

Pandemi di sisi lain melahirkan etos kedermawanan dan rasa simpati, empati kepada sesama semakin menjamur dan mendorong profesionalitas dalam pengelolaan lembaga filantropi seperti BAZNAS, LAZ, LAZISMU, LAZISNU, Dompet Dhu'afa, Solopeduli, Al Azhar Peduli, Al Hidayah Peduli, berbagai NGO menggalang dana kemanusiaan penanggulangan Covid-19. Sehingga muncul programprogram yang visioner strategis dalam aksi tanggap darurat penanggulangan bencana non alam, bahkan bisa dikembangkan dalam program-program penanggulangan bencana lainnya.

Program-program kedermawanan mulai menjamur di berbagai daerah menjadi solusi mengurai masalah sosial, seperti warteg gratis, gratis makan di warung HIK, jumat berkah dimana setiap hari jumat ada sedekah dari jamaah untuk jamaah masjid, gerakan subuh berjamaah dilanjutkan sarapan bersama jamaah yang merupakan donasi jamaah, pengajian ahad pagi, SPBU gratis BBM untuk jamaah yang 
membaca Alquran beberapa juz. Bedah rumah gratis, pembagian sembako rutin kepada jamaah.

Gerakan kedermawanan dimotori berbagai lembaga dan masjid-masjid visoner seperti Masjid Jogokariyan Yogyakarta yang menginspirasi bagaimana masjid dikembangkan sebagai pusat peradaban, kesehatan dan pusat ekonomi jamaah. Masjid menjadi embrio untuk pemberdayaan umat yang lebih masif lagi, sehingga etos kedermawanan menjadi modal sosial yang sangat bagus.

Gerakan sosial interprenuership terus bergerak menjadi etos kerelawanan, kepedulian, filantropi. Orang yang terjun ke dunia kerelawanan merasakan hati dan pikirannya menjadi tenang, dampak sosial yang dirasakan menjadi etos sosial yang tinggi. Merasakan hati dan pikiran tenang, penuh kebermaknaan hidup karena membantu mereka yang membutuhkan. Orang merasa bahagia dapat berbagi, orang lain terbantu, sekalipun bantuan tersebut sepele, sederhana, mudah dilakukan banyak orang. Merasakan power of giving merasuk dalam sanubari dan jiwa raganya, menjadi bermaknaan hidupnya.

Hasil penelitian sosial para antropolog, sosiolog membuktikan data-data positif tentang kemakmuran seseorang dan wilayah tertentu karena keberkahan harta yang mereka miliki ambil contoh Zuly Qodir (2002: 131) membuktikan risetnya dengan judul Agama Etos Dagang berangkat dari pertanyaan "Benarkah spirit keagamaan secara langsung memberikan pengaruh pada prilaku hidup atau etos pada pemeluknya? Islam sebagai agama kerja, agama sosial, agama keimanan telah membuktikan. Sehingga para psikolog juga membuktikan dengan riset yang serius untuk membuktikan dari data-data lapangan implementasi doktrin agama dalam kehidupan sosial. 
Islam itu indah, damai, sejahtera, makmur, berbagi, tolong menolong, kemajuan dan keunggulan. Alquran dan Hadis sangat indah menggambarkan kehidupan ideal sumber perilaku kehidupan manusia. Namun praktiknya masih ada kesenjangan seharusnya dengan senyatanya. Karena itu nilai-nilai normatif ajaran Islam sekuat tenaga diwujudkan dalam realitas kehidupan.Tugas dakwah setiap muslim membuktikan ajaran Islam tangguh hadapi aneka masalah sosial.

\section{Jogo Tonggo}

Peranan lingkungan meliputi keluarga, teman-teman, dan lingkungan masyarakat tempat kita berada. Karena merekalah kita belajar dan mendapat nilai-nilai tentang kepedulian sosial. Nilai-nilai yang tertanam itulah yang nanti akan menjadi suara hati kita untuk selalu membantu dan menjaga sesama. Kepedulian sosial sebenarnya bukanlah perilaku sosial untuk mencampuri urusan orang lain, tetapi lebih pada bagaimana dan dengan cara apa orang atau kelompok membantu menyelesaikan permasalahan yang dihadapi orang lain dengan tujuan kebaikan karena merasa terpanggil, iba, dan tidak tega membiarkannya (Ravik Karsidi, 2021: 93).

Jogo tonggo mendorong terbentuknya kesadaran bersama dan ketaatan warga masyarakat Jawa Tengah pada himbauan pemerintah. Jogo tonggo dianggap sebagai salah satu konsep percepatan pageblug (wabah penyakit) dan menempatkan masyarakat sebagai garda terdepan bersama dengan pemerintah untuk menghadapi penularan Covid-19 (Muh. Fajar Shodiq, 2021: 424). Donasi Jogo tonggo dihimpun dari warga sekitar yang peduli terhadap warga yang lain yang terpapar Covid-19. Setiap warga yang terpapar Covid-19 lingkungan sekitar melakukan upaya 
Jogo tonggo untuk memenuhi segala kebutuhan terkait dengan logistik dan kesehatan keluarga. Satuan Tugas (Satgas) yang ada di lingkungan memberikan data keluarga yang terpapar Covid-19. Pihak Rukun Tetangga mengkonsolidasikan kepada semua warga untuk memberikan bantuan dan mengirim makanan maupun bahan makanan bila tidak bisa memasak ataupun mengolah sendiri.

Di era pandemi Corona, dengan akar budaya guyub, gotong royong, gugur gunung menjadi jaring pengaman sosial kemanusiaan sevcara kultural tumbuh kembali di berbagai tempat. Banyak kalangan, baik lembaga maupun personal sebelum pemerintah memberikan bantuan yang secara birokratik lebih rumit, lambat, bergotong royong melakukan aksi tanggap darurat dengan cara beragam. Menurut Islah memberikan bantuan, perhatian yang lebih fokus pada keluarga dan masyarakat pada setiap aspek yang dibutuhkan dalam kehidupan sehari-hari, seperti membagikan sembako, nasi bungkus, masker, hand sanitizer, dan hal-hal lain yang dibutuhkan (Islah Gusmian, dalam Abd. Halim, dkk, 2020: 124).

Seperti tudi yang dilakukan (Mansur Efendi, 2021: 119) menunjukkan minat dan kemauan yang besar masyarakat akan etos kedermawanan telah membentuk karakter bangsa Indonesia di tengah pandemi bahkan dalam setiap momen yang mengundang empati masyarakat untuk berdonasi, besar kecilnya tidak terlalu diperhitungkan, namun bentuk partisipasi dan semangat filantropinya yang sangat mengagumkan. Sehingga menjamur Lembaga sosial yang terus lahir dari kekuatan power of giving. Dimana ada kekyakinan kuat masyarakat karena pemahaman terhadap 
doktrin keagamaan yang telah sampai dan dipahami dan diyakini sebagai kebaikan yang terus mengalir.

Secara psikologis orang yang memberikan akan mempunyai efek terhadap hormon ketenangan batin dan sekaligus menjadi kekuatan terhadap masyarakat sekitar. Sedekah atau derma yang dikeluarkan benar-benar ikhlas akan memberikan rasa ketenangan jiwa bagi orang yang mengeluarkan, apalagi ada janji teologis yang langsung dibaca dan dirasakan oleh donator.

Melihat transparansi dan pengiriman donasi yang diberikan dan langsung diterima manfaatnya. Sehingga menjamurnya lembaga sosial keagamaan atau lembaga donasi yang terkumpul dari tingkat yang paling rendah dalam keluarga, lingkungan rukun tetangga, rukun warga, desa/ kelurahan, kecamatan, kabupaten/kota, provinsi, negara dan bangsa di berbagai belahan dunia melakukan model pemberdayaan dan donasi dalam berbagai kegiatan kemanusiaan.

Filantropi merupakan perilaku kedermawanan yang berorientasi pada kecintaan terhadap manusia. Biasanya berupa tindakan memberi bantuan kepada orang lain, baik berupa bantuan uang, barang maupun tenaga. Dalam ajaran Islam, tradisi ini serupa dengan perintah zakat, infak, dan sedekah. Bagi masyarakat muslim semangat filantropi menguat seiring dengan ritual datangnya bulan suci Ramadhan yang dijadikan momentum kebangkita etos kedermawanan mayoritas umat Islam. Tidak terkecuali di Indonesia ini. Masyarakat menyadari bulan suci Ramadhan mempunyai nilai strategis dari spiritual maupun material, sebab pahala orang yang berderma mendapatkan kelipatan pahala beramal di bulan suci, secara material kegiatan ekonomi semakin masif yang menyebabkan kebutahan stok 
makanan meningkat dan perputaran uang juga meningkat hingga menjadi gerakan ekonomi dan sosial yang lebih besar, belum lagi efek ekonomi dari tradisi mudik lebaran yang berpengaruh besar terhadap system ekonomi yang terjadi.

\section{Penutup}

Pandemi telah mengajarkan kearifan, kedermawanan, filantropi dari level individu, kelompok, grup media sosial, komunitas senasib seperjuangan, sejawat di tempat kerja, mitra bisnis, rukun tetangga, rukun warga, dusun, desa, kelurahan, kecamatan, Kabupaten, provinsi, hingga tingkat nasional, bahkan di level global antar negara bahu membahu memberikan bantuan lunak yang bersifat charity kepada bangsa lain yang menghadapi pandemi lebih parah membutuhkan uluran tangan dari negara lain. Jogo tonggo sebagai etos kedermawanan di masa pandemi menjadi solusi dalam membangun solidaritas warga. Etos tersebut sangat bermanfaat dalam setiap kondisi sosial yang terjadi baik dalam masa krisis dan tanggap darurat maupun saat aman.

\section{Daftar Pustaka}

Efendi, Mansur. 2021. Pengelolaan Filantropi Islam di Tengah Pandemi Covid-19 (Studi pada Komunitas Kurir Sedekah), Filantropi: Jurnal Manajemen Zakat dan Wakaf , 2. (1): 119.

Gusmian, Islah. 2020. "Pandemi Covid-19, Informasi Ilmiah, dan Solidaritas Kemanusiaan" dalam Abd. Halim, dkk, Rahayu Nir Sambikala Refleksi Dosen IAIN Surakarta Selama \#dirumahsaja, Surakarta: IAIN Press.

SF, Ihsan. dan Rabbani, Abdullah. 2017. 
Menyongsong PTMT Pada Dunia Pendidikan

Karsidi, Ravik. 2021. Bersahabat Dengan Zaman Kolom-Kolom Prof. Dr. Ravik Karsidi, MS., Pengantar Prof Dr Muhadjir Effendy, MAP., Solo: Solopos.

Qodir, Zuly. 2002. Agama Etos Dagang, Yagyakarta: LP3ES.

Shodiq, Muh Fajar. 2021. "Jogo Tonggo" Efektivitas Kearifan Lokal, Solusi Pandemi Covid-19, Salam: Jurnal Sosial dan Budaya Syar-i. Volume 8 Nomor (2): pp.423-440. DOI: 10.15408/sjsbs.v8i2.19412. 


\title{
PERSIAPAN PRAKTIK MICROTEACHING MAHASISWA PGMI PASCA PANDEMI
}

\author{
Nazri Adlani, M.Pd 21 \\ IAIN Takengon
}

"Persiapan mikroteacig diawali dengan persiapan mahasiswa menguasai teknik mengajar yang disampaikan pada mata kuliah tertentu, dengan membuka, menutup pelajaran serta memberikan penguatan."

\section{Microteaching}

Cetiap kampus tentu ingin lulusan alumninya menjadi - lulusan yang terbaik, baik dari segi kualitas alumni di bidang pendidikan maupun sifat akhlakul karimah setiap alumni. Pencapaian tersebut menciptakan lulusan yang dapat di terima di masyarakat secara luas. Menjadi pengajar yang berkualitas, tentu memerlukan latian khusus yang dilakukan mahasiswa. Mahasiswa harus sering dan banyakbanyak berlatih mengajar di kampus maupun di sekolah

${ }^{21}$ Nazri Adlani, M.Pd. di lahirkan di Aceh Tenggara 25 Juni 1991. Menyelesaikan Pendidikan Sekolah Dasar pada Tahun (2003) di SDN Terutung Pilun Kutacane, Sekolah Menengah Pertama Tahun (2006) di SMPN 3 Kutacane. Melanjutkan Sekolah Menengah Atas tahun (2009) di SMAN 1 Kutacane. Kemudian memperoleh gelar Sarjana Pendidikan (S.Pd) S1 Pendidikan Biologi di Universitas Gunung Leuser Kutacane Aceh Tenggara Lulus Tahun (2015) dan Lulus dengan Predikat Cumlaude Gelar Magister (S2) di Bidang Pendidikan Guru Madrasah Ibtidaiyah (PGMI) di Universitas Islam Negeri Sunan Kalijaga (UIN-Suka) Yogyakarta tahun (2018). Penulis merupakan dosen Prodi PGMI di IAIN Takengon pada tahun 2019-sekarang. 
agar mempunyai banyak pengalaman mengajar. Namun semua itu terhalang dan terbatas di saat dunia dilanda dengan kegalauan akibat masuknya wabah virus covid 19 yang terjadi mulai di bulan maret 2020 di Indonesia. Pada bulan april 2020 akhirnya semua aktifitas di lakukan secara jarak jauh atau WFH. Tidak terkecuali kegiatan kampus juga di laksanakan secara daring, baik mengajar maupun kegiatan praktik microteaching mahasiswa PGMI. Kejadian tersebut menyebabkan kegiatan di kampus sangat tidak efektif. Pada dasarnya kegiatan ini di lakukan secara nyata oleh mahasiswa, dari tahapan mikroteaching di kelas kemudian di laksanakan PPL (Praktik Pengalaman Lapangan) di sekolah. Alhamdulilah pasca pandemi sekarang sebagian aktifitas kini sudah mulai normal dan hampir semua kegiatan pun sudah bisa dilaksanakan secara PTM (Pembelajaran Tatap Muka).

Microteacing merupakan salah satu bentuk model praktik atau pelatihan mengajar bagi calon guru di kampus. Kegiatan microteaching sangat penting bagi mahasiswa PGMI yang di laksanakan secara langsung di kampus sebagai bekal untuk mereka yang sudah semester 5 atau 6 sebelum melaksanakan tugas PPL di sekolah. Praktik microteaching ini mengarah kepada dukungan kompetensi calon guru agar menjadi profesional. Hal ini sesuai dengan undang-undang nomor 14 tahun 2005 tentang guru dan dosen menuntut adanya kualifikasi sarjana guru tersebut maka Program Pengalaman Lapangan (PPL) di bidang keguruan atau microteaching menjadi sangat penting untuk mahasiswa PGMI. (Undang-Undang Republik Indonesia No 14 Tahun 2005 Tentang Duru dan Dosen, 2005)

Kegiatan microteaching atau pengajaran mikro harus mampu meningkatkan kemampuan dan wawasan 
mahasiswa sebagai calon guru agar lebih siap dan tangguh dalam menghadapi masalah pendidikan. Kegiatannya dilakukan secara berkelompok di dalam ruangan. Kegiatan microteaching bertujuan untuk membantu mahasiswa PGMI sebagai calon tenaga pendidik menguasai keterampilan mengajar secara khusus agar tidak kesulitan pada saat mengajar sesungguhnya, sebagai kompetensi pembelajaran bagi calon tenaga pendidik, dan mengembangkan bakat serta kemampuan mahasiswa untuk belajar dan menemukan kelemahan ketika mengajar prasekolah.

Microteaching merupakan pengajaran yang dilakukan dalam skala kecil untuk merancang dan mengembangkan keterampilan baru dan memperbaiki keterampilan lama.(Azizah \& Rahmi, 2019: 197)

James B. Brown mengatakan tugas dan peranan seorang pendidik yaitu menguasai dan mengembangkan materi pelajaran, kemudian merencanakan dan mempersiapkan materi pelajaran sehari-hari, sehingga guru dapat mengontrol dan mengevaluasi kegiatan pembelajaran (Nana Sudjana, 2001: 142).

Microteaching merupakan usaha menyederhanakan keseluruhan proses belajar mengajar yang ada secara sistematis (Bahri Jamarah Syaiful, 2002: 125). Sebelum melaksanakan microteaching mahasiswa telah melaksanakan perkuliahan dengan mata kuliah tertentu sebagai persyaratan melaksanakan microteaching.(Ardi, 2014: 77)

Konsep pengajaran mikroteaching dilandasi oleh pokok pikiran ada 7 yaitu:

1. Pengajaran yang nyata yang dilaksanakan dalam bentuk sebenarnya tetapi berkonsep kecil 
2. Latihan terpusat pada keterampilan dasar mengajar, menggunakan informasi dan pengetahuan tentang tingkat belajar siswa sebagai umpan balik terhadap kemampuan calon guru

3. Pengajaran dilaksanakan bagi siswa dengan latar belakang yang berbeda dan berdasarkan pada kemampuan intelaktual kelompok usia tertentu

4. Pengontrolan secara ketat terhadap lingkungan latihan yang di selengarakan dalam ruangan microteaching

5. Pengadaan low threat situation untuk memudakan calon guru/dosen mempelajarai keterampilan mengajar

6. Penyediaan low risk situation yang kemungkinan siswa berpatisipasi aktif dalm pengajaran

7. Penyediaan kesempatan latihan ulang dan pengaturan distribusi latihan dalam jangka waktu tertentu.(Sardiman, 2005: 145)

Berdasarkan peraturan pemerintah Nomor 19 Tahun 2005 Standar Pendidikan Nasional, dimana dalam Bab VI pasal 3 dimuat kompetensi guru sebagai berikut :

1. Kompetensi pedagogic

2. Kompetensi kepribadian

3. Kompetensi profesional dan

4. Kompetensi sosial. (Pemerintah, 2005: 8)

\section{Persiapan Praktik Microteacing}

Persiapan mikroteacig diawali dengan persiapan mahasiswa menguasai teknik mengajar yang disampaikan pada mata kuliah tertentu. Mikroteaching ini dilaksankan dengan persiapan keterampilan yang dimiliki mahsiswa. 
Keterampilan tersebut yaitu keterampilan membuka dan menutup pelajaran, menjelaskan, mengadakan variasi,

memberikan penguatan, bertanya, mengelola kelas, mengajar perorangan/kelompok kecil, dan membimbing diskusi kelompok kecil.(Ardi, 2014: 79)

Hasil penelitian Murdiyanto memberikan gambaran persiapan praktik mikroteacing yang suda dilakukan, yaitu:

1. Loka karya penyusunan program dan revisi hasil loka karya.

2. Pembekalan pratik pengajaran mikro sebanyak dua kali pertemuan

3. Pelaksanaan praktik pengajaran mikro

4. Evaluasi teradap kekurangan pembelajaran mikro.(Moerdiyanto, 2005: 30)

Hal yang perlu dipersiapkan sebelum melaksanakan simulasi mengajar adalah :

1. Pengelolaan di tingkat prodi dengan menyediakan team teaching dosen dalam 4 SKS

2. Dilaksanakan dalam semester 6 PGMI

3. Mahasiswa menyediakan RPP sebelum melaksanakan microteching.

4. Mahasiswa melaksanakan 10 keterampilan dasar mengajar.

5. Mahasiswa diberikan teori teknik dasar mengajar, teori kurikulum, dan perencanaan pembelajaran, teori pelaksanaan pembelajaran, dan teori evaluasi pembelajaran.

6. Dosen membimbing praktik mengajar microteaching. (Sihotang \& Simorangkir, 2020: 67) 
10 Keterampilan Dasar Mengajar

1. Membuka Pembelajaran

2. Menjelaskan

3. Mengadakan Variasi

4. Bertanya

5. Membimbing Diskusi

6. Mengajar Perorangan

7. Memberi Penguatan

8. Mengelola Kelas

9. Memberikan Media

10. Menutup Kelas

\section{Daftar Pustaka}

Ardi, M. (2014). Pelaksanaan pembelajaran bagi mahasiswa program studi PPKn STKIP-PGRI Pontianak. Jurnal Edukasi, 1(88), 77.

Azizah, N., \& Rahmi, E. (2019). Persepsi Mahasiswa Tentang Peranan Mata Kuliah Micro Teaching Terhadap Kesiapan Mengajar Pada Mahasiswa Pendidikan Ekonomi UNP. Jurnal Ecogen, 2(2), 197. https://doi.org/10.24036/jmpe.v2i2.7312

Jamarah Syaiful, B. (2002). Micro Teaching. Bumi Aksara.

Moerdiyanto. (2005). Artikel Jurnal Mikro Teaching. Produktivitas Pembelajaran MIkro, 30.

Pemerintah. (2005). PP Nomor 19 Tahun 2005 tentang Standar Nasional Pendidikan. Evaluation, 36(C), 2005-2008.

Undang-Undang Republik Indonesia No 14 Tahun 2005 Tentang Duru dan Dosen, (2005).

Sardiman. (2005). Belajar Pembelajaran. Rineka Cipta.

Sihotang, H., \& Simorangkir, S. T. (2020). Buku Pedoman Praktik Microteaching. UKI Press. http://repository.uki.ac.id/1863/1/BUKU PEDOMAN Praktik.pdf

Sudjana, N. (2001). Penilaian Hasil Proses Belajar Mengajar. Rosdakarya. 


\section{EFEKTIVITAS PEMBELAJARAN DARING DI MASA PANDEMI CORONA VIRUS DISEASE (COVID I9)}

\section{Petrus Anton Tage Saka, S.Pd 22 \\ SMP Negeri 4 Wolowaru}

"Efektifitas pembelajaran daring di masa Pandemi Covid 19 ini menegaskan bahwa setiap perubahan yang menantang para pendidik dan peserta didik harus bisa disikapi dengan

pola pikir yang baru bahwa inovasi pendidikan terus berkembang, dan pembelajaran daring menjadi sebuah pilihan yang telah dipertimbangkan"

$\mathrm{P}$ eran guru dalam perjalanan sejarah bangsa indonesia sungguh besar dan sangat menentukan. Boleh dikatakan tidak tergantikan oleh teknologi secanggih apapun .Sejak masa penjajahan, guru selalu menanamkan kesadaran akan harga diri sebagai bangsa dan menanamkan semangat nasionalisme kepada peserta didik dan masyarakat. Pada tahap awal kebangkitan nasional, para guru aktif dalam organisasi pemuda pembela tanah air dan pembina jiwa serta semangat para pemuda pelajar.

22Penulis lahir di Ende, 25 Oktober 1976, Penulis merupakan Guru yang mendapat tugas tambahan sebagai Kepala Sekolah pada SMP Negeri 4 Wolowaru Kecamatan Wolojita Kabupaten Ende,Penulis menyelesaikan gelar Sarjana Pendidikan Biologi Universitas Negeri Nusa Cendana Kupang (2000). Penulis pernah menerima Penghargaan Guru Terbaik jenjang SMP Tahun 2021. 
Undang-undang nomor 14 tahun 2005 tentang guru dan dosen menegaskan bahwa guru adalah pendidik profesional dengan tugas utama mendidik, mengajar, membimbing,mengarahkan,melatih, menilai dan mengevaluasi peserta didik pada pendidikan anak usia dini jalur pendidikan formal, pendidikan dasar dan pendidikan menengah. Dengan demikian guru merupakan salah satu faktor yang strategis dalam menentukan keberhasilan pendidikan yang meletakan dasar serta turut mempersiapkan pengembangan potensi peserta didik untuk masa depan bangsa.

Pandemi Covid 19 yang menyebar sejak desember 2019 hingga saat ini telah mengacaukan berbagai aspek kehidupan sosial,ekonomi, kesehatan dan yang paling penting adalah Pendidikan. Semua Negara telah berjuang melawan serangan covid tersebut dengan strategi masingmasing agar tidak semua warganya terpapar dan bahkan harus meninggal dunia. Kasus corona virus yang penyebaran sangat cepat ini mendapat perhatian duni internasional dan kasus ini sudah menjadi kasus dunia.

Wuhan adalah salah satu kota di Cina sebagai relung paling pertama virus ini berkembang dan menginfeksi warganya.Berita dan informasi pergerakan virus tersebut telah meramaikan laman media karena sebaran virus ini semakin hari semakin masif. Penyebarab ke orang lain tanpa mengenal usia inilah yang Membutuhkan perhatian serius dari diri sendiri maupun Pemerintah. Pemerintah indonesia sudah banyak mengeluarkan kebijakan solutif agar penyebaran virus ini dapat ditekan penyebarannya. Salah satu keputusan pemerintah yang memberi dampak luas adalah kebijakan pada bidang Pendidikan, baik pada komponen praktisi maupun regulasi dan lingkungan. 
Kebijakan yang diambil oleh pemerintah merubah semua pola pembelajaran yang dilaksanakan dengan tatap muka fisik langsung kini bergeser dengan melejit menuju ke metode Daring maupun ofline visit home learning. Kajian pemerintah terkait pembelajaran daring ini sebenarnya bertujuan untuk menekan laju angka terpapar covid $19 \mathrm{di}$ jenjang para Pelajar maupun mahasiswa. Berbagai upaya yang diambil oleh pemerintah maupun pelaku pendidikan di lapangan semata-mata untuk mencerdaskan anak bangsa di negeri indonesia tercinta ini. Seiring dengan berbagai upaya solutif yang diambil, kasus covid 19 ini akhirnya merubah minshet para pendidik untuk tidak tertinggal dengan model pembelajaran daring yang bagi para guru terasa sangat baru bahkan belum mengenal seperti apakah model pembelajaran daring tersebut. Kemudahan media sosial melalui android HP ataupun Jenis media lainnya menuntut guru untuk terus berubah, menanggapi inovasi pembelajaran dengan media baru melalui model pembelajaran Daring.

Sri Harnani,S.Pd dalam tulisannya yang berjudul Efektivitas Pembelajaran Daring di Masa Pandemi Covid19 Menjelaskan bahwa Pembelajaran Daring (dalam jaringan) merupakan sistem pembelajaran tanpa tatap muka /fisik secara langsung antara guru dan siswa melalinkan melalui online yang menggunakan jaringan internet. Guru harus memastikan bahwa kegiatan pembelajaran tetap berjalan, meskipun siswa berada di rumah. Solusinya guru dituntut dapat mendesain media pembelajaran sebagai inovasi dengan memanfaatkan media daring (online). Hal ini sesuai dengan Edaran Mentri Pendidikan dan Kebudayaan Republik Indonesia Nomor 4 Tahun 2020 tentang Pelaksanaan Kebijakan Pendidikan dalam masa Darurat 
Penyebaran Corona Virus Disease (COVID19). Sistem pembelajaranpun bergeser dari pertemuan fisik menuju ke media perangkat personal Computer ( PC )atau laptop yang terhubung dengan jaringan internet. Guru akan bertemu dan melaksanakan pembelajaran dengan peserta didik melalui media sosial WhatsApp (WA), telegram,instagram, aplikasi zoom, google clasroom, dan google meet, dengan demikian guru bisa memastikan bahwa peserta didik akan mengikuti pembelajaran walaupun di tempat yang berbeda dalam waktu yang sama.

Kelumpuhan terjadi di semua sektor kehidupan dan salah satunya adalah sektor pendidikan. Kenyataan membuktikan bahwa kesulitan dalam belajar dan mengajar terlihat jelas di masa pandemi covid 19 ini. Salah satu kenyataan yang dialami adalah tidak semua peserta didik dan orangtua memiliki sarana pendukung untuk pelaksanaan pembelajaran secara Daring, selain itupula belum tentu anak yang memiliki sarana seperti HP,laptop, memiliki koneksi jaringan internet. Kondisi yang paling sulit adalah peserta didik yang berada di daerah pedalaman yang tidak memiliki koneksi internet. Aturan dan kebijakan pemerintah agar peserta didik yang berada di zona merah penyebaran covid 19 belum boleh melaksanakan kegiatan tatap muka, ini menjadi kasus yang serius yang harus ditangani oleh pihak sekolah agar peserta didiknya setidak tidaknya merasakan sentuhan pelajaran dari para guru. Salah satu solusi yang diambil oleh pihak sekolah adalah dengan melaksanakan Pembelajaran Jarak Jauh secara luring misalnya Anak diberikan bahan ajar dalam bentuk modul/rangkuman materi serta tugas dan selanjutnya peserta didik secara mandiri belajar melalui modul tersebut dan menyelesaikan tugas yang diberikan oleh guru, 
selanjutnya ada kesepakatan antara guru dan peserta didik untuk memastikan kapan tugas tersebut dikumpulkan. Proses pembelajaran luring ini pula bisa melalui siaran Televisi, dan Pembelajaran melalui Siaran pemancar Radio seperti RRI. Khusus untuk daerah yang jangkauan pemncar RRI dan Televisi tidak dapat dijangkau maka anak hanya bisa belajar dari modul yang diberikan oleh guru.

Permasalahan pembelajaran daring yang paling urgen adalah ketersediaan kuota internet dan kepemilikan sarana seperti komputer, Handphone ( HP ) bagi peserta didik dari orangtua yang ekonominya rendah, hal ini tentu akan dibebankan kepada orangtua yang ingin anaknya menerima pembelajaran secara Daring. Diberbagai media sosial sangat ramai diperbincangkan pengalaman para orantua mendampingi anaknya saat belajar dari rumah secara Daring, kenyataan yang ditemukan bahwa banyak orang tua yang tidak sabaran terhadap anaknya yang sulit diatur saat menerima pembelajaran secara daring, sering orangtua marah-marah dan bahkan ada orangtua yang putus asa jika respon anak sangat rendah, sehingga banyak orangtua yang menginginkan agar anaknya segara kembali ke sekolah untuk menerima pelajaran secara tatap muka bersama dengan guru di sekolah.

Kejadian yang dialami oleh orangtua di rumah saat mendampingi anaknya belajar membuktikan bahwa mendidik anak untuk menjadi pintar itu tidaklah mudah, diperlukan kesabaran yang sangat besar. Sehingga orangtua perlu menyadari dan mengetahui bagaimana cara membimbing anak-anak untuk belajar di rumah. Apapun kondisi saat ini, pembelajaran harus tetap berjalan dan perlu disadari bahwa ketidaksiapan guru dan siswa terhadap pembelajaran daring juga menjadi sebuah 
permasalahan. Mutasi pembelajaran konvensional tatap muka ke pembelajaran Daring terasa sangat cepat dan mau tidak mau tetap harus dilaksanakan. Kesiapan melaksanakan pembelajaran daring oleh sekolah juga ditantang untuk terus berinovasi sehingga proses pembelajaran tetap dilaksanakan.

Pembelajaran daring di masa Pandemi Covid 19 ini adalah pilihan yang tepat karena pembelajaran ini tidak menghadirkan peserta didik di kelas melainkan peserta didik dan guru berada di tempat terpisahpun boleh melaksanakan kegiatan pembelajaran. Tujuan Pemerintah melahirkan program pembelajaran daring adalah penekanan laju penyebaran kasus covid19 terlebih terbentuknya klaster baru di lingkungan sekolah. Beberapa Keunggulan dalam proses pembelajaran daring adalah

1. Guru dan siswa mampu menggunakan aplikasi pembelajaran Daring

2. Pelaksanaan pembelajaran akan lebih fleksibel karena tidak hanya dilaksanakan di sekolah saja, namun pelaksanaanya bisa dari rumah ataupun di mana saja asal koneksi jaringan internetnya memadai

3. Penyebaran Kasus Positif Corona Virus Disease berkurang

4. Kesehatan dan keselamatan guru dan peserta didik diprioritaskan

5. Adanya kesepakatan antara Guru dan peserta didik kapan akan dilaksanakan proses pembelajaran

Adapun Kelemahan dari pembelajaran Daring adalah:

1. Kodrat Makhluk Sosial dari manusia bergeser ke perilaku Egois untuk diri sendiri karena Guru dan 
Peserta didik Tidak bertemu fisik namun online/ dalam jaringan.

2. Sering terjadi kesalah pahaman antara peserta didik dan Guru dalam proses pembelajaran karena tidak terjadi kontak fisik serta jaringan yang tidak selalu bersahabat dengan kita.

3. Peserta didik yang berdomisili pada wilayah yang belum memiliki jaringan internet akan sangat sulit mengikuti pembelajaran daring

4. Belum semua peserta didik atau guru yang memiliki kemampuan dalam memanfaatkan aplikasi pembelajaran online

5. Muncul Sikap tidak jujur, tidak tepat waktu dalam mengumpulkan tugas, Mencontek pekerjaan teman atau Plagiat.

6. Kompetensi siswa sulit diukur karena hasil pekerjaan peserta didik belum sepenuhnya adalah benar pekerjaan peserta didik bisa saja orangtua yang menyelesaikannya.

7. Komunikasi antara guru dan peserta didik menjadi sangat tidak efektif karena komunikasi terjadi saat pembelajaran secara online saja.

8. Orangtua jarang bertemu guru di sekolah, bahkan konsultasi peserta didik dilaksanakan secara online dalm jaringan.

Pada prinsipnya kesehatan dan keselamatan anak yang diprioritaskan pada masa ini, karena generasi yang sedang bertumbuh ini akan terus menjadi investasi bangsa yang terbesar untuk membangun Negara Tercinta ini. Model pembelajaran yang diterapkan dalam kondisi sulit ini pun harus bervariasi sehingga peserta didik tidak merasa jenuh 
dan dibebani dengan segudang tugas yang menumpuk, karena jika demikian sama halnya dengn memberi beban kepada anak dan akan berpengaruh kepada kondisi fisik kesehatan anak, misalnya saja jika semua guru memberikan tugas secara Online maupun ofline dalam satu minggu untuk semua mata pelajaran yang diterimanya di kelas, dengan batas waktu pengumpulan yang sudah ditentukan minggu berikutnya maka dapat dipastikan bahwa tidak semua anak dalam satu kelas menyelesaikan tugas tersebut dengan baik dan tepat pada waktunya serta muncul kejenuhan dari peserta didik karena seluruh aktivitasnya hanya bersama komunitas kecil yaitu keluarga, dan mereka ingin kembali ke komunitas besar yaitu sekolah untuk bergabung bersama sahat-sahabatnya, para guru dan bisa berinteraksi sosial secara lebih baik.

Imelda Wahyuni dalam tulisannya yang berjudul "Dinamika Pembelajaran Daring Pada Masa Pandemi Covid 19" mengatakan bahwa Kondisi pembelajaran pada masa pandemi harus dapat dimanfaatkan dengan perubahan pola pikir, pola belajar, pola interaksi ilmiah yang lebih bermakna sehingga kekakuan dalam menyikapi masa covid 19 dapat dimaksimalkan dengan produktivitas yang bercirikan kebermaknaan. Perasaan pobia diminimalisir dengan optimis bahwa seluruh aktivitas tetap berlangsung dengan protokol kesehatan tatanan baru (New Normal) Khususnya dalam segmen penyelenggaraan pendidikan, baik pendidikan pra sekolah hingga pendidikan tinggi.

Pada Akhirnya Kajian dari tulisan efektifitas pembelajaran daring di masa Pandemi Covid 19 ini menegaskan bahwa setiap perubahan yang menantang para pendidik dan peserta didik harus bisa disikapi dengan pola pikir yang baru bahwa inovasi pendidikan terus 
berkembang, dan pembelajaran daring menjadi sebuah pilihan yang telah dipertimbangkan dengan nurani bening untuk keselamatan pendidik dan peserta didik meskipun muncul tantangan besar seperti ketersediaan jaringan internet, kepemilikan gawai, Plagiasi, juga kejenuhan sosial karena interaksi peserta didik hanya dengan komunitas kecil yaitu keluarga. Namun tujuan dari pembelajaran daring adalah pelayanan pendidikan secara total kepada peserta didik dengan tetap menjaga kesehatan dan keselamatan pendidik dan peserta didik. 
Menyongsong PTMT Pada Dunia Pendidikan 


\title{
URGENSI LITERASI DIGITAL PASCA PANDEMI COVID-I9
}

\section{Femi Fauziah Alamsyah, S.sos., M.Hum, ${ }^{23}$ \\ Universitas Muhammadiyah Bandung}

\begin{abstract}
“Literasi digital menjadi sangat urgen di masa pasca pandemi seperti saat ini, agar masyarakat memiliki pedoman dalam melakukan segala kegiatan digital"
\end{abstract}

\begin{abstract}
pa yang pertama kali anda fikirkan ketika mendengar - kata "Pandemi"? mungkin kita tidak pernah menyangka akan mengalaminya. Hampir dua tahun Dunia mendapat guncangan dahsyat akibat wabah virus corona, termasuk Indonesia. Tidak hanya sektor kesehatan yang terdampak, tapi juga sektor yang lainnya, seperti sosial, budaya, terlebih lagi ekonomi. Warga bumi bersama-sama berjuang untuk bertahan hidup di tengah gentingnya "Pandemi Covid-19".

Pandemi merubah seluruh tatanan hidup masyarakat, hingga lahirlah kata "Adaptasi Kehidupan Baru", seolah olah kita sedang terlahir kembali di tempat yang sama namun suasananya berbeda. Dalam waktu yang singkat kita dituntut untuk berubah mengikuti pola baru, maka tidak heran jika banyak yang masih merasa kaku dan terkesan melanggar karena tidak biasa.
\end{abstract}

23Penulis lahir di Bandung, 04 Juni 1991, penulis merupakan Dosen Universitas Muhammadiyah Bandung dalam bidang Ilmu Komunikasi dan Budaya, penulis menyelesaikan gelar Sarjana Sosial jurusan Ilmu Komunikasi Jurnalistik di UIN Sunan Gunung Djati Bandung (2012), sedangkan gelar Magister Humaniora diselesaikan di Universitas Padjadjaran Program Studi Kajian Budaya (2016), 
Salah satu tuntutan yang hadir dari pandemi ini adalah Transformasi Teknologi Digital, dengan adanya ketentuan sosial distansing (mengurangi aktifitas kontak fisik) kita dituntut untuk lebih melek digital, karena segala aspek kehidupan terutama yang ada kaitannya dengan interaksi sosial tidak lagi dilakukan secara langsung melainkan dalam jaringan (daring), dengan otomatis hal ini dapat merubah kebiasaan masyarakat dalam berfikir dan bertindak.

Pada dasarnya teknologi digital sudah mulai berkembang sejak munculnya revolusi industri 4.0, yaitu adanya tranformasi produksi industri yang menggabungkan antara industri konvensional dan teknologi digital atau internet,

Di mana data menjadi sesuatu yang sangat penting. Interkonektivitas, otomatisasi, machine learning, dan real time data menjadi prioritas industri global.

Pada pertengahan abad ke-19, Friedrich Engels dan Louis Auguste Blanqui memperkenalkan istilah revolusi industri, kira-kira sejak tahun 1750-an. Berawal dari mesin uap yang mendominasi industri saat itu (Revolusi Industri 1.0), kemudian penggerak turbin, samapi saat ini memasuki revolusi industri ke 4 atau Revolusi Industri 4.0

Revolusi Industri 4.0 muncul ditandai dengan adanya terobosan-terobosan baru di bidang teknologi yang meliputi bidang luas seperti kecerdasan buatan (Artificial Inteilligence-AI), internet untuk segala (Internet of ThingsIoT)), kendaraan otomatis, pencetakan 3 dimensi (3D), nanoteknologi, bioteknologi, sains material, penyimpanan energy, serta komputasi kuantum. (Schwab:2019)

Jelas sekali, ciri khas dari revolusi industri 4.0 adalah digitalisasi, dimana masyarakat mengalami perubahan 
berfikir dan cara hidup menjadi serba digital. Terlebih lagi saat pandemi, masyarakat dunia termasuk di Indonesia mau tidak mau di tuntut untuk masuk dalam kebiasaan baru. Disitulah awal mula terjadinya transformasi digital, perubahan besar dari digitalisasi yang nantinya akan melahirkan budaya digital (digital culture).

Kini kata digitalisasi tidak hanya seputar teknis, melainkan lebih menyeluruh pada tatanan kehidupan yang membentuk kultur. Kebiasaan dalam bersikap reflektif dan berkembangnya pengetahuan serta keterampilan masyarakat mengenai teknologi akan mempengaruhi perkembangan budaya digital.

Skinner (2018) melukiskan situasi masyarakat di era digital, ia menegaskan bahwa digitalisasi planet ini sedang menghasilkan sebuah transformasi besar. Semua orang di bumi akan terlibat di dalam jaringan dan semua orang di bumi akan mendapatkan kesempatan berbicara, berdagang atau berbisnis serta bertransaksi dengan semua orang lainnya dalam waktu nyata.

Nampaknya selama masa pandemi hingga pasca pandemi kita sudah mulai terbiasa dengan kehidupan serba digital, hal ini bisa menjadi faktor penyebab meningkatnya taraf hidup atau bahkan sebaliknya, semua memang terlihat serba mudah dan cepat, tapi bisa jadi kita termanipulasi oleh teknologi digital itu sendiri.

Dalam seminar daring yang diselenggarakan oleh Universitas Parahyangan (2020), Prof. Ignatius berkata bahwa Budaya digital dimaksudkan lebih luas dari konteks keberadaan revolusi industry 4.0 atau society 5.0. Budaya digital ditandai dengan kombinasi deep learning dan genetic engineering. Dampak positif yang meningkatkan kapasitas kemampuan manusia dan sebaliknya dampak negatif yang 
harus diwaspadai, dipaparkan dan dibahas secara mendalam.

Adapun dampak positif sebagai berikut:

1. Kelemahan manusia dapat diatasi. Dengan teknologi digital yang canggih setiap kekurangan dan kelemahan masusia bisa disiasati, seperti daya ingat manusia bisa di optimalisasikan, penyakit langka dapat disembuhkan, hambatan komunikasi akan terminimalisir, begitupun tranportasi dirasa semakin efisien, dan juga aspek lainnya.

2. Kemampuan manusia dapat ditingkatkan. Sumber daya atau potensi yang dimiliki manusia dapat diperluas dan dimaksimalkan. Misalnya, manusia mampu untuk melihat kenyataan yang sebelumnya sulit untuk di tembus, dengan teknologi digital seolah-olah segala sesuatu sudah tidak ada lagi batas.

3. Dunia semakin transparan. Manusia sudah tidak lagi terhalang oleh ruang dan waktu, kita mengalami seakan-akan melihat apa yang terjadi di belahan bumi manapun.

4. Sharing culture di perluas. Setiap orang menjadi lebih mudah untuk berbagi kultur, seluruh dunia semakin terhubung satu sama lain dan empati semakin berkembang luas.

Sedangkan dampak negatif kurang lebih sebagai berikut:

1. Bercampur aduknya kenyataan dan hoax. Karena kebesasan dalam menginformasikan segala hal kita mudah tertipu oleh berita yang simpang siur, antara fakta dan hoax sulit untuk dibedakan. Seolah-olah 
setiap orang memiliki kebebasan untuk membuat sensasi tanpa adanya rasa tanggung jawab. Lebih disayangkan lagi, ketiak orang pembuat sensasi bisa bersembunyi atas nama mesin algoritma.

2. Kehidupan pribadi seolah diterobos. Kata privasi sudah mulai menipis, informasi tentang identitas menjadi transparan dan dikonsumsi oleh publik.

3. Waktu terbuang percuma. Disadari atau tidak, banyak waktu dihabiskan untuk hal-hal yang kurang penting, setiap hari kita sibuk dengan produk teknologi digital yang adiktif. Secara tidak disadari kemudian kita tidak lagi produktif memanfaatkan waktu yang ada.

4. Cyber crime atau kejahatan dunia maya. Seperti yang kita tahu, banyak sekali kejahatah-kejahatan yang terjadi di dunia maya, diantaranya cyber bullying, penyebaran nama baik, pornografi, dan lainnya.

Pasca pandemi kita dihadapkan pada situasi yang tidak mudah untuk dijalani, ada peluang sekaligus tantangan di dalamnya. Masyarakat harus meningkatkan life skil untuk mengasah potensi diri dalam beradaptasi dengan kebiasaan baru (kebiasaan digital). Dengan kata lain perkembangan tranformasi digital harus diimbangi juga dengan perkembangan tranformasi mental, dalam hal ini ada tiga perkara yang harus dibangun yaitu: cara berpikir, bersikap dan menyakini sesuatu. Jika ketiganya berjalan beriringan maka akan lahir kesejahteran dalam pembangunan dan peningkatan kualitas manusia.

Hal lain yang tak kalah penting dalam menghadapi kultur digital pasca pandemi adalah kecakapan literasi digital, tujuannya untuk mengarahkan masyarakat agar 
lebih bijak dalam menggunakan teknologi. Sutrisna (2020) mengatakan bahwa pada masa pandemi covid-19, setiap individu perlu menguasai bahwa literasi digital merupakan hal penting yang dibutuhkan untuk dapat berpartisipasi di dunia modern dan menganti-sipasi penyebaran informasi negatif pada masa pandemi covid-19. United Nations Educational, Scientific and Cultural Oganization (UNESCO: 2011) mendefinisikan literasi digital sebagai kemampuan individu untuk mengakses, memahami, membuat, mengomunikasikan, dan mengevaluasi informasi melalui teknologi digital. Sedangkan Gilster (dalam Pratiwi \& Pritanova, 2017) mengartikan literasi digital sebagai kemampuan memahami dan menggunakan informasi dalam banyak format dari berbagai sumber ketika itu disajikan di komputer.

Kegiatan literasi digital selama ini identik dengan kemampuan seseorang dalam menggunakan serta memahami pemanfaatan teknologi informasi dan komunikasi, misalnya dalam mendukung dunia pendidikan dan ekonomi. Japelidi mengelompokkan literasi digital menjadi 10 kompetensi, yaitu: Mengakses, Menyeleksi, Memahami, Menganalisis, Memverifikasi, Mengevaluasi, Mendistribusikan, Memproduksi, Berpartisipasi, dan Berkolaborasi. (Kurnia \& Wijayanto, 2020)

Pradana (2018) menjelaskan bahwa literasi digital memiliki empat prinsip dasar, yaitu:

1. Pemahaman. Artinya masyarakat memiliki kemampuan untuk memahami informasi yang diberikan media, baik secara implisit ataupun eksplisit.

2. Saling ketergantungan. Artinya antara media yang satu dengan lainnya saling bergantung dan 
berhubungan. Media yang ada harus saling berdampingan serta melengkapi antara satu sama lain.

3. Faktor sosial. Artinya media saling berbagi pesan atau informasi kepada masayrakat. Karena keberhasilan jangka panjang media ditentukan oleh pembagi serta penerima informasi.

4. Kurasi. Artinya masyarakat memiliki kemampuan untuk mengakses, memahami serta menyimpan informasi untuk dibaca di lain hari. Kurasi juga termasuk kemampuan bekerja sama untuk mencari, mengumpulkan serta mengorganisasi informasi yang dinilai berguna.

Literasi media digital sebagai suatu rangkaian kegiatan melek media, gerakan melek media dirancang untuk meningkatkan kontrol individu terhadap media yang mereka gunakan untuk mengirim dan menerima pesan. Kemudian dalam hal ini melek media dipandang sebagai sebuah keterampilan yang bisa berkembang di dalam sebuah rangkaian dimana kita tidak selalu melek terhadap media dalam semua situasi, setiap waktu serta terhadap semua media. (Baran dan Dennis: 2010).

Pada intinya, literasi media digital merupakan skill untuk menilai makna dalam setiap jenis pesan, mengorganisasikan makna itu sehingga berguna, dan kemudian membangun pesan untuk disampaikan kepada orang lain. Literasi digital menjadi sangat urgen di masa pasca pandemi seperti saat ini, agar masyarakat memiliki pedoman dalam melakukan segala kegiatan digital. Masyarakat tidak lagi banyak melakukan pelanggaranpelanggaran digital dan lebih cakap dalam memanfaatkannya. Ketika masyarakat mulai sadar tentang 
literasi digital maka yang akan muncul saaat menggunakan teknologi digital adalah dampak postif, bukan dampak negatif, seperti kasus-kasus pornografi, penyebaran nama baik, penyebara berita bohong (HOAX), bullying, body shaming, dan yang lainnya.

\section{Daftar Pustaka}

Baran, Stanley J. \& Dennis K. Davis. 2010. Teori Komunikasi Massa Dasar, Pergolakan, dan Masa Depan. Jakarta: Salemba Humanika.

Kurnia, Novi \& Wijayanto, Xenia Angelica. 2020. Kolaborasi sebagai kunci: membumikan kompetensi literasi digital Japelidi. Yogyakarta: Program Studi Magister UGM.

Pradana, Yudha (2018). Atribusi Kewargaan Digital dalam Literasi Digital. Untirta Civic Education Jurnal. Vol. 3 No. 2.

Pratiwi, N \& Pritanova, N. (2017). Pengaruh Literasi Digital Terhadap Psikologis Anak Dan Remaja. Semantik, Vol 6. No 1

Schwab, Klaus. 2019. Revolusi Industri keempat (terjemahan). Jakarta: Gramedia Pustaka Utama.

Skinner, Chris. 2008. Manusia Digital (Revolusi Digital 4.0 Melibatkan Semua Orang). Jakarta: Elex Media Komputindo.

Sutrisna, I. P. G. (2020). Gerakan Literasi Digital Pada Masa Pandemi Covid-19. Stilistika: Jurnal Pendidikan Bahasa dan Seni. Vol.8 No. 2.

UNESCO. 2011. Digital Literacy in Education. Moscow: UNESCO Institute for Information Technologies in Education 


\title{
DEGRADASI BUDI PEKERTI \\ PASCA PANDEMI
}

\author{
Saepul Bahri, S.Pd. ${ }^{24}$ \\ Yayasan Al-Falah Al-Karimi
}

"Formula untuk memberantas partikel-partikel yang bisa membuat terdegradasinya Budi Pekerti para peserta didik, dengan upaya yang harus dilakukan oleh para tenaga pengajar agar senantiasa para peserta didik memiliki kualitas yang tak terbatas walaupun dalam keadaan pandemi"

Hampir genap 2 tahun Bumi Pertiwi ini di rundung Pandemi Covid-19 yang meluluhlantahkan Dunia dengan korban meninggal yang bervarian. Korban yang berjatuhan meniggal dunia atau yang mengalami kritis bahkan ada yang pulih kembali. Semua Negara-Negara di Dunia mengalami kepanikan yang luar biasa sehingga penanganan setiap negara hampir berbeda-beda.

Namun, kita bukan untuk membahas mengupas tuntas mengenai pandemi melainkan proyeksi jangka panjang

${ }^{24}$ Saepul Bahri, anak ketiga dari lima bersaudara pasangan dari Yudianto dan Dewi Habsoh lahir pada tanggal 23 Agustus 1988 pada hari senin pukul 19.00 Wib. Sekolah Dasar SDN Ciranjang 3 lulus Thun 2000 dan MTS Nurul Islam Affandiyah lulus Tahun 2003 dan melanjutkan SLTA ke SMK PGRI 3 Otomotif Cianjur dan Lulus Tahun 2007. Kemudian dilanjutkan ke Perguruan Tinggi Swasta di Cianjur dengan Jurusan Pendidikan Jasmani Kesehatan dan Rekreasi Fakultas Keguruan dan Ilmu Pendidikan Universitas Suryakancana Cianjur masuk Tahun 2011 dan lulus Tahun 2016. 
daripada pandemi tersebut terlebih pendidikan. Ketika pandemi melanda Bangsa tercinta Kita maka otomatis kegiatan belajar mengajarpun disesuaikan karena disinyalir penyebaran meluas di dunia pendidikan khususnya sekolah.

Semua upaya dilakukan oleh berbagai pihak mulai dari pemerintah pusat yang akan disampaikan kepada para tenaga pengajar diseluruh Indonesia strategi apa yang akan diterapkan agar proses belajar mengajar tetap terlaksana. Kemudian Pemerintah menginisiasi Proses Belajar Mengajar dengan System Daring (Dalam Jaringan) terbukti kesungguhan Pemerintah dalam merealisasikannya dengan menyuplai kuota untuk Para Guru dan Peserta Didiknya. Tapi Pemerintah tidak memahami nasib para peserta didik yang tidak memiliki handphone atau bahkan lokasi peserta didik yang berada di pelosok yang sangat sulit terjangkaunya jaringan internet.

Semakin maraknya Game Online juga patut kita antisipasi dengan cermat, bagaimana meminimalisir penggunaan handphone dan bermain game pada anak usia remaja, tanpa kita sadari kebutuhan penggunaan internet sangat kita prioritaskan karena mengikuti kemajuan zaman yaitu Era Globalisasi yang serba digitalisasi. Namun kita sebagai tenaga pendidik juga harus bijaksana dalam melakukan pembelajaran daring karena ditakutkan para peserta didik akan melanjutkan dengan bermain game setelah pembelajaran usai atau menonton konten-konten yang tidak berfaedah sehingga bisa memicu rusaknya mental para peserta didik.

Keresahan pun terjadi karena dengan adanya kesenjangan secara materi maka selanjutnya peserta didik akan sedikit tertinggal dengan rekan lainnya yang memiliki jaringan yang cukup bagus sehingga tidak terganggu proses 
belajar mengajarnya melalui internet. Yang lebih di khawatirkan masa depan Generasi Bangsa yaitu Para Pemuda, setelah di perhatikan secara seksama melalui berbagai media khususnya media internet. Mereka seakan kehilangan identitas diri mereka selaku seorang Pelajar. Hal ini terlihat dan terbukti dengan semakin maraknya sikap atau prilaku yang mereka lakukan, seperti begadang, memberhentikan truk yang sedang melaju sehingga memicu kecelakaan lalulintas. Karena tidak adanya aktivitas belajar mengajar disekolah para peserta didik tidak menghiaraukan kedispilinan waktu sehingga begitu banyak waktu yang tersia-sia salah satunya digunakan untuk begadang.

Pertama tanda ataupun ciri mereka terindikasi kehilangan indetitas yaitu cara mereka berbicara, sering terdengar oleh telinga kita jika para peserta didik masih belum menggunakan Bahasa yang tepat dan benar, terlebihi dikota-kota kecil yang memiliki Bahasa daerah yang khas, penggunaan Bahasa yang tepat merupakan salah satu tanda peserta didik tersebut merupakan seorang pelajar. Karena ketika diperhatikan masih ada peserta didik menggunakan Bahasa untuk rekan sebaya namun dipergunakan kepada orang yang lebih tua darinya, hal ini bukan tugas Guru Bahasa, namun tugas kita semua. Bagaimana membiasakan para peserta didik untuk tetap

Kemudian salah satu tanda atau identitas seorang pelajar yaitu penampilan. Di era pasca pandemi ini kita sering sekali melihat para pelajar yang menampilkan dirinya bak seperti artis anak band yang identik slalu diberikan warna pada rambutnya atau bahkan meniru artis korea yang membuming di Indonesia. Dan ternyata tanpa ada rasa malu sedikitpun dengan penuh rasa bangga. Terlihat ketika bertemu diluar jam sekolah mereka seakan- 
akan tidak mengakuinya sebagai tindakan yang kurang tepat. Jika hal sepele seperti ini kita biarkan maka jangan salahkan mereka jika kelak akan melakukan kesalahan yang lebih fatal dan lebih besar sehingga berdampak kepada social, ekonomi serta budaya. Untuk memunculkan kebiasaan kedisplinan setiap sekolah memiliki aturan dan ketentuan yang diberlakukan disekolah.

Selanjutnya ciri daripada seorang pelajar yaitu prilaku, prilaku merupakan salah satu tolak ukur dalam suatu penilaian seseorang yang ada dihadapan kita, dan kita sudah barang tentu mengetahui perbedaan prilaku yang sekolah dan yang tidak sekolah. Jika di Agama Islam istilah lain daripada prilaku ialah Ahlak, sebagaimana tuntunan kita selaku umat muslim yang berpedoman kepada prilaku Nabi Muhammad Sholullohualaihiwassallam, selain sebagai Nabi dan Rosul yang terakhir Nabi Muhammad Sholullohualaihiwassallam juga sebagai utusan penyempurna ahlak. Sampai detik ini pun nama Nabi Muhammad Sholullohualaihiwassallam terjejer di barisan teratas yaitu ke 1 dalam bukunya "The 100" yang dicetak oleh Michael H Hart, seorang Astronot dan ahli sejarah terkenal sebagai orang yang paling berpengaruh dalam panggung sejarah Dunia, buku yang bergenre Pengetahuan tersebut terbit pertama pada Tahun 1978 yang berisi 576 halaman kemudian dicetak ulang Pada Tahun 1992. Sebagai Rosul dan Nabi terakhir Nabi Muhammad Sholullohualaihiwassallam bahwa kita harus memiliki Ahlak yang mulia atau Ahlakul Karimah, Beliau selalu mencontohkan untuk slalu tidak membalas kejahatan dengan kejahatan bahkan menyeru kita untuk membalas kejahatan dengan kebaikan. Tenaga pengajar yang belum dilegalisasi tidak akan menyulutkan semangat untuk tetap 
bisa berkontribusi dalam hal kebaikan dan kemaslahatan. Karena selain daridapa mengamalkan ilmu yang di dapat di Perguruan Tinggi, kita juga sepatutnya menjadikan segala perbuatan kita di niatkan sebagai amal, karena beramal tidak hanya melulu dengan harta dan benda, melainkan juga bisa dengan menebarkan kebaikan kepada sesama manusia dan caranya pun berbeda-beda tergantung kepada kesanggupan kita. Mengajar dengan penuh keikhlasan dan ketulusan akan membuahkan hasil yang sangat berbeda pula.

Mari kita sama-sama perhatikan dengan cermat para peserta didik kita yang ada di lingkungan belajar kita, baik secara Psikologi maupun fisiologi dan melakukan pendeketan secara emosional kepada mereka. Apakah kedua elemen tersebut berpengaruh terhadap Degradasi Budi Pekerti atau tidak, apakah hanya berlaku bagi kalangan lingkungan pendidikan yang berada di kawasan pelosok atau daerah terpencil saja. Apakah ada upaya khusus untuk mereka yang berada di daerah terpencil agar bisa mendapatkan pembelajaran yang layak. Karena pembelajaran yang layak hanya akan didapatkan jika proses pembelajaran bersifat menyeluruh dan bersifat merata dari segi apa pun, baik secara sarana atau bahkan prasarana untuk menunjang kegiatan belajar mengajar. Dan kami Sangat mengharapkan formula untuk memberantas partikel-partikel yang bisa membuat terdegradasinya Budi Pekerti para peserta didik, bagaimana dan upaya yang harus dilakukan oleh para tenaga pengajar agar senantiasa para peserta didik memiliki kualitas yang tak terbatas walaupun dalam keadaan pandemi seperti ini. Misalnya laboratorium untuk menyelidiki kasus tersebut sehingga kami para 
Menyongsong PTMT Pada Dunia Pendidikan

tenaga pengajar bisa dengan maksimal dalam prosesi "Mencerdaskan Kehidupan Bangsa". 


\title{
IMPLEMENTASI MODEL PEMBELAJARAN EXPERIENTIAL LEARNINGPADA MATA KULIAH PENDIDIKAN KARAKTER DI TENGAH PANDEMI COVID-I9
}

\author{
Hermus Hero, S.Ag., M.Pd.25 \\ Universitas Nusa Nipa Indonesia
}

"Perlu ada pembimbingan dan pembinan karakter yang baik dari para pendidik (dosen), terutama kegiatan kemahasiswaan yang mengakomodir tujuan pengembangan karakter mahasiswa"

$\mathrm{P}$ andemi Covid-19, telah mengubah banyak aspek kehidupan manusia termasuk pada aspek pendidikan formal di sekolah mulai dari PAUD hingga perguruan tinggi. Kebijakan pemerintah untuk menerapkan pola pembelajaran tatap muka terbatas adalah salah satu upaya untuk menekan angka penyebaran Covid-19 (2021). Segala aktivitas yang berhubungan dengan kegiatan mengumpulkan warga dalam jumlah besar harus dihindari. Hal ini merupakan salah satu tantangan tersendiri untuk meningkatkan kualitas kehidupa masyarakat. Aspek

25Penulis lahir di Ewa, Maumere, Flores, NTT pada tanggal 21 September 1974 menamatkan pendidikan S1 Pendidikan Agama Katolik pada tahun 2005 di Institut Pastoral Indoensia (IPI) Malang, Jawa Timur. Kemudian penulis melanjutkan pendidikan S2 Kebijakan dan Pengembangan Pendidikan di Pascasarjana Universitas Muhammadiyah Malang dan tamat pada tahun 2012. Sejak tahun 2012 bertugas sebagai Dosen Pendidikan Karakter dan Pendidikan Agama Katolik pada Program Studi PGSD Universitas Nusa Nipa Indonesia di Maumere, Flores, NTT. 
pendidikan dilihat sebagai salah satu aspek yang memiliki dampak besar akibat merebaknya wabah virus corona.

Sekolah yang biasanya terjadi dan berproses dalam dinamika akademik yang mengumpulkan warga sekolah dalam jumlah besar harus menempuh alternatif dengan menerapkan pembelajaran tatap muka terbatas. Guru dan dosen dituntut oleh situasi dan kondisi yang baru untuk menerapkan pembelajaran dengan model yang lebih adaptif. Pembelajaran dengan model experiential learning adalah salah satu model holistik dari proses pembelajaran dimana peserta didik belajar, tumbuh dan berkembang dengan menekankan pengalaman sebagai sumber belajar utama yang membedakannya dari teori belajar lainnya. Dalam pembelajaran tertentu, subjek belajar tidak cukup sampai pada tahap penalaran atau kognitif tetapi perlu lanjutan yang masuk pada ranah afektif dan psikomotorik. Dalam sebuah pembelajaran yang membutuhkan pendekatan experiential learning maka tindakan nyata atau aplikatif adalah pola yang tepat untuk mengakselerasi pemahaman dari apa yang dipelajari.

Pembelajaran pada mata kuliah Pendidikan Karakter dalam pelaksanaannya dirancang lebih variatif dan kaya bentuk sehingga tidak monoton pada muatan teori melulu. Banyak bentuk pembelajaran pendidikan karakter yang dijejali dengan sejumlah teori sampai mengabaikan konsep praksis dan implementasi pelaksanaannya di tengah masyarakat. Sepatutnya perlu disadari bahwa dengan melihat orang akan lupa, tetapi dengan melakukan atau berbuat orang akan terus mengingat dan melakukan hal yang sama di lain kesempatan. Untuk itu perlu dirancang pembelajaran Pendidikan Karakter yang juga menonjolkan tindakan aplikatif dalam kehidupan sehari-hari. 
Menurut Lickona (1991: 51), karakter adalah "A reliable inner disposition to respond to situation ia a morally good way. Character so conceived has three interrelated parts: moral knowing, moral feeling, and moral behaviour." Bagi Lickona, karakter mulia (good character) meliputi pengetahuan tentang kebaikan (moral feeling), lalu menimbulkan komitmen (niat) terhadap kebaikan (moral behaviour). Dengan kata lain, karakter mengacu pada serangkaian pengetahuan (cognitive), sikap (attitudes), dan motivasi (motivations) serta perilaku (behaviours)dan keterampilan (skills). Jika demikian model Pendidikan Karakter yang bagaimanakah yang dapat ditawarkan di tengah pandemi Covid-19 ini?

Ulasan tentang Pendidikan Karakter model experiential learning dilakukan sebagai bentuk respon terhadap keadaan wabah Covid-19 dan bagaimana upaya agar proses pendidikan tetap berjalan dan tidak mandek. Adapun model experiential learning dilakukan dengan membagi mahasiswa dalam kelompok kecil beranggotakan 4-5 orang. Setiap kelompok menganalisis satu pokok materi terkait misalnya karakter peduli sosial. Kelompok mendalami materi, membuat kajian, menganalisa sampai menemukan bentuk implementasi apa yang dapat dilakukan sebagai aktualisasi dari karakter tersebut. Selanjutnya jika kelompok telah menyelesaikan pendalaman materi, kajian dan analisis maka kelompok akan menentukan sasaran yang akan dituju dari implementasi kegiatan karakter misalnya di panti asuhan untuk kelompok yang menganalisa karakter peduli sosial.

Penulis berpendapat bahwa untuk semakin mendukung pengalaman belajar maka pola pendukung lainnya pun dilakukan agar mahasiswa semakin mengalami 
banyak fase belajar dan dapat menemukan banyak aktivitas yang memperkaya hidupnya. Dari kelompok kecil yang terbangun itu mereka akan melakukan observasi ke salah satu panti asuhan untuk meminta izin mengadakan kegiatan bakti sosial di panti asuhan tersebut. Jika mereka telah diterima di panti tersebut dan diizinkan untuk mengadakan kegiatan bakti sosial sebagai wujud karakter peduli sosial maka mahasiswa dapat menyesuaikan dengan harapan panti untuk beberapa alternatif kegiatan misalnya live in di panti asuhan, memasak dan memberi makan untuk penghuni panti asuhan atau melakukan kegiatan lain yang menunjukkan kepedulian pada sesama. Aktivitas ini tidak hanya berhenti sampai di sini tetapi dilanjutkan dengan reflektive pedagogic untuk memberi makna yang terkandung dari kegiatan tersebut. Dalam hal ini para mahasiswa menuliskan pengalaman dan memaknai dari kegiatan tersebut sekiranya apa yang telah mendorong mereka melakukan kegiatan tersebut dan makna atau nilai apa yang telah didapatkan. Hasil pikiran dan refleksi mahasiswa tersebut dibimbing secara baik dan kontinyu sehingga akhirnya terhimpun dalam buku kumpulan refleksi mahasiswa.

Kegiatan ini telah berlangsung dari waktu ke waktu dan dari informasi dan evaluasi yang didapatkan bahwa pihak tempat kegiatan berlangsung sangat mengapresiasi bentuk kegiatan ini dan para mahasiswa peserta mata kuliah pendidikan karakter juga memiliki bekal lebih dan pengalaman yang sangat unik dan mengesankan belajar mata kuliah pendidikan karakter. Dalam hal ini model pembelajaran terbatas pada masa pandemi Covid-19 pun tetap terpenuhi sebab komposisi mahasiswa yang belajar tidak beranggotakan dalam jumlah besar dan efketifitas 
pembelajaran pendidikan karakter pun lebih dapat tercapai (2021). Di samping itu belajar sungguh-sungguh memberikan pengalaman nyata kepada mahasiswa karena tidak hanya mendegar atau melihat tetapi belajar dengan melakukan sesuatu hal yang berguna bagi dirinya (learning by doing).

Sebenarnya tidak sulit bagi para pendidik (dosen) untuk membantu dan memfasilitasi para mahasiswa untuk belajar dan menerapkan ilmu pengetahuan berdasarkan pengalaman hidup sehari-hari. Para mahasiswa dalam kelompoknya dapat memetakan berbagai persoalan karakter dan degradasi nilai yang terjadi di lingkungan sekitar. Dengan mengenal berbagai persoalan karakter dan pengembangannya yang perlu diperhatikan, maka akan dengan mudah mahasiswa menganalisis strategi pengembangan karakter dan nilai yang perlu diimplementasikan dalam kehidupannya sehari-hari. Oleh dari itu, perlu ada pembimbingan dan pembinan karakter yang baik dari para pendidik (dosen), terutama kegiatan kemahasiswaan yang mengakomodir tujuan pengembangan karakter mahasiswa, sehingga para mahasiswa tidak terjerumus dalam pola pikir, pola sikap dan pola tingkah laku yang bertolak belakang dengan nilai-nilai karakter yang dijabarkan dan diharapkan tumbuh-berkembang di lingkungan kampus dan dalam kehidupan bermasyarakat (Bera, et.al., 2021).

\section{Daftar Pustaka}

Bera, Lukas ; Yufrinalis, Marianus ; Hero, Hermus. (2021). Filosofi Mior Dadin Sebagai Internalisasi Pendidikan Karakter Peserta Didik di Kecamatan Doreng Kabupaten 
Sikka.

Al-Mashalah,

$9(02)$

483-492.

doi:http://dx.doi.org/10.30868/am.v9i02.1780

Direktorat Jenderal PAUD Dikdas dan Dikmen Kemendikbud-

Ristek RI. 2021. Pembelajaran Tatap Muka Dilakukan

Secara Terbatas. Diakses melalui HYPERLINK

"https://ditpsd.kemdikbud.go.id/artikel/detail/pembelaj

aran-tatap-muka-dilaksanakan-secara-terbatas"

https://ditpsd.kemdikbud.go.id/artikel/detail/pembelaja

ran-tatap-muka-dilaksanakan-secara-terbatas pada tanggal 15 November 2021

Kemendikbud. 2021. Salinan Keputusan Bersama Menteri

Pendidikan dan Kebudayaan, Menteri Kesehatan, Menteri

Agama, dan Menteri Dalam Negeri RI tentang Panduan

Penyelenggaraan Pembelajaran di Masa Pandemi Covid-19.

Diakses melalui HYPERLINK

"https://jdih.kemdikbud.go.id/arsip/SKB\%204\%20MENT

ERI\%20PANDUAN\%20PEMBELAJARAN\%20TATAP\%20

MUKA.pdf"

https://jdih.kemdikbud.go.id/arsip/SKB\%204\%20MENT

ERI\%20PANDUAN\%20PEMBELAJARAN\%20TATAP\%20

MUKA.pdf pada tanggal 15 November 2021

Lickona, T. (191). Educating for Character : How Our School Can

Teach Respect and Responsibility. New York: Bantam Books.

Yufrinalis, Marianus. (2021). Melawan Stigma Sosial Akibat

Pandemi Covid-19. In A. Wijayanto, Transformasi Dunia

Pendidikan Dalam Percepatan SDM Ungggul (pp. 195202). Tulungagung: Akademia Pustaka.

Yufrinalis, Marianus. (2021). Menakar Kesiapan dan Partisipasi

Peserta Didik Dalam Pembelajaran Daring Selama Masa Pandemi Covid-19 di Kabupaten Sikka, NTT. In A. Wijayanto, Akademisi dan Jurus Jitu Pembelajaran Daring (pp. 147-154). Tulungagung: Akademia Pustaka. 


\section{PENTINGNYA MENCUCI TANGAN SEBAGAI TINDAKAN PENCEGAHAN COVID-I9}

Silvi Aryanti, M.Pd 26

Universitas Sriwijaya

"Terhentinya sebaran virus Covid-19 yaitu dengan cara praktik cuci tangan secara berkala wajib dilakukan. Pasalnya tidak hanya kontak dekat dengan orang yang terinfeksi melalui sekresi mulut dan hidung. Tetapi, melakukan cuci tangan dengan sabun dan air mengalir menjadi sangat penting untuk pencegahan"

\section{Pendahuluan}

Covid-19 telah menjadi pandemi di seluruh negara dunia, virus ini pertama kali terjadi di Cina khususnya Kota Wuhan kemudia virus tersebar dengan cepat ke negara lain (Supriatna, 2020). Pandemi Covid-19 membuat terjadinya perubahan kebiasaan masyarakat. Salah satu kebiasaan yang dapat dilihat yaitu kebiasaan perilaku hidup bersih. Perilaku hidup sehat yaitu mencuci tangan merupakan gerakan $3 \mathrm{M}$ (mencuci tangan dengan sabun, memakai masker dan menjaga jarak) pada kehidupan new normal. Hal ini bertujuan agar dapat dicegah penyebaran

26Penulis lahir di Palembang, 21 Juli 1991, penulis merupakan Dosen Program Studi Pendidikan Jasmani, Kesehatan, dan Rekreasi Fakultas Keguruan dan Ilmu Pendidikan Universitas Sriwijaya, penulis menyelesaikan pendidikan Sarjana (S1) Pendidikan Prodi Penjaskes di FKIP Universitas Sriwijaya (2012), dan menyelesaikan pendidikan S2 di Universitas Negeri Yogyakarta Ilmu Keolahragaan Konsentrasi Pendidikan Olahraga (2015). 
dan terhindar dari penularan virus covid-19 (Mardiana, dkk, 2020). Pandemi covid-19 ini menjadikan masyarakat mau tidak mau agar perilaku hidup bersih dan sehat dijalankan dan hal tersebut sebagai newnormal (Kemenkes RI, 2020). Penularan Covid-19 dapat melalui udara dan menempel pada benda-benda yang ada di sekitar. Seseorang dengan tidak menyadari memegang benda-benda yang tidak tahu kebersihan, berkumpul dalam keramaian, dan tidak menjaga jarak. Oleh sebab itu, dibutuhkan suatu tindakan untuk mencegah Covid-19.

Pemerintah menerapkan suatu pencegahan Covid-19 yaitu menjaga jarak dalam melakukan komunikasi sosial, menjaga kesehatan, kerumunan dihindari, dan memutuskan rantai penularan dengan rajin mencuci tangan dengan sabun (Astuti, 2020). Cuci tangan menggunakan sabun merupakan salah satu upaya pencegahan dan penularan penyakit. Cuci tangan pakai sabun membuat kuman dapat dibunuh sebanyak 73\% dan lebih efektif membunuh kuman penyakit. Hal ini lebih baik daripada mencuci tangan dengan hand sanitizer yaitu membunuh kuman sebanyak 60\% (Cordita dkk, 2019). Pelaksanaan cuci tangan khususnya di Indonesia menggunakan sabun merupakan upaya agar mata rantai mikroorganisme termasuk virus sebagai sumber penyakit dapat diputuskan (Asthiningsih \& Wijayanti, 2019).

Pentingnya mencuci tangan menggunakan air bersih dan sabun sebelum dan setelah melakukan aktivitas. Hal ini bertujuan agar seseorang dapat terhidar dari Covid-19. Kebiasaan mencuci tangan sebaiknya ditanamkan dari dalam diri sendiri. Selain itu, pemerintah telah menyiapkan fasilitas cuci tangan dan sabun untuk masyarakat. 


\section{Pembahasan}

Cara yang paling mudah namun sangat esensial selama pandemi Covid-19 adalah dengan melakukan cuci tangan menggunakan sabun (Rahmawati, Utomo \& Ahsanah, 2020). Menurut panduan dari WHO, UNICEF, dan IFRC dalam Key Messages and Actions for COVID-19 Prevention and Control in Schools, prinsip dasar menjaga siswa, guru, dan staf agar tetap aman di sekolah dan membantu penyebaran penyakit ini terhenti adalah cuci tangan harus diberlakukan pada sekolah secara teratur dengan air bersih dan sabun (WHO, 2020). Hasil kegiatan edukasi tentang manfaat dan prosedur langkah-langkah melakukan cuci tangan yang benar. Hal ini bertujuan untuk pengetahuan diberikan kepada masyarakat dan upaya mencegah penularan virus Covid 19 (Purba, dd, 2021).

Mencuci tangan menggunakan air bersih dan sabun sangat penting dilakukan pada masa pandemi Covid-19. Hal ini dilakukan karena seseorang secara tidak sadar menyentuh benda-benda yang bisa melekat pada bakteri/virus. Pemerintah telah melakukan sosialisasi pentingnya mencuci tangan dan menyiapkan tempat untuk mencuci tangan dan juga sabun.

\section{Penutup}

Virus covid-19 menyebar kepada seseorang yaitu secara langsung, tidak langsung (melalui benda atau permukaan yang terkontaminasi), atau kontak dekat dengan orang yang terinfeksi melalui sekresi mulut dan hidung, melakukan cuci tangan dengan sabun dan air mengalir menjadi sangat penting. Terhentinya sebaran virus Covid19 yaitu dengan cara praktik cuci tangan secara berkala wajib dilakukan. 


\section{Referensi}

Andriyansyah, M. F., \& Margarettha, V. (2021). Kampanye Pentingnya Himbauan Mencuci Tangan Melalui Media Pamflet di Masa Pandemi Covid-19. Jurnal Pembelajaran Pemberdayaan Masyarakat (JP2M), 1(4), 294-299.

Asthiningsih, N. W., \& Wijayanti, T. (2019). Edukasi Personal

Hygiene Pada Anak Usia Dini Dengan G3CTPS. Jurnal

Pesut : Pengabdian Untuk Kesejahteraan Umat, 1 (2), 8492.

Astuti, N. A. R. (2020) "Pemerintah: 7 Provinsi- 41 Kabupaten/Kota Tetapkan Status Siaga Darurat Corona", News.Detik.Com.

Cordita R, Soleha T, Mayasari D.(2019).Perbandingan Efektivitas Mencuci Tangan MenggunakanHand Sanitizerdengan Sabun Antiseptik pada Tenaga Kesehatan di Ruang ICU RSUD Dr. H. Abdul Moeloek.J Agromedicin.6(1).

Kementerian Kesehatan. (2020). Menuju Adaptasi Kebiasaan Baru. Direktorat Promosi Kesehatan \& Pemberdayaan Masyarakat.

Mardiana, U., Novitriani, K., Virgianti, D. P., \& Irmayanti, E. (2020). Upaya Peningkatan Kebiasaan Mencuci Tangan Sebagai Bagian Dari Gerakan 3 M Melalui Donasi Sabun Cuci Tangan Hasil Produksi Tim Kelompok Pengabdian Masyarakat Stikes Bth Tasikmalaya.Jurnal Pengabdian Masyarakat (Jupemas), 1(2).

Pradana, K. A., Peristiowati, Y., Ellina, A. D., Widiyanto, A., \& Atmojo, J. T. (2021). Pengaruh Pendidikan Kesehatan Animasi Lagu Anak-Anak Terhadap Pengetahuan Cuci Tangan Pakai Sabun (Ctps) Anak Usia Sekolah Pada Masa Pandemi Covid-19 Di Desa Gembol Ngawi. Avicenna: Journal of Health Research, 4(1).

Purba, I. E., Munthe, S. A., \& Bangun, H. A. (2021). Enam Langkah Mencuci Tangan Yang Benar Dalam Pencegahan Penularan Virus Covid 19. Jurnal Abdimas Mutiara, 2(2), 14-24. 
Rahmawati, N. V., Utomo, D. T. P., \& Ahsanah, F. (2020). Fun handwashing sebagai upaya pencegahan covid-19 pada anak usia dini. Jurnal Masyarakat Mandiri, 4(2), 218.

Supriatna, E. (2020). Wabah Corona Virus Disease (Covid 19) Dalam Pandangan Islam. SALAM: Jurnal Sosial dan $\begin{array}{lll}\text { Budaya Syari, } & \text { 7(6), 555-564. }\end{array}$ https://doi.org/10.15408/sjsbs.v7i6.15247

WHO. (2020, March). Key Messages and Actions for Covid-19 Prevention and Control in Schools. Dipetik March 25, 2020, dari who.int: https://www.who.int/docs/defaultsource/coronaviruse/key-messages-andactions-for-covid19-prevention-and-control-in-schoolsmarch2020.pdf?sfvrsn=baf81d52_4 
Menyongsong PTMT Pada Dunia Pendidikan 


\title{
PANDEMI DAN GERAKAN \\ MAN I PIDIE PEDULI BERBAGI
}

\author{
Darwin, S.Ag.,MH 27 \\ Madrasah Aliyah Negeri 1 Pidie
}

"Jumlah siswa yang cukup besar memberikan peluang bagi MAN 1 Pidie untuk berkontribusi secara nyata pada keluarga siswa dan masyarakat sekitar melalui gerakan MAN 1 Pidie peduli berbagi"

\section{Pendahuluan}

Cebagai suatu lembaga pendidikan, MAN 1 Pidie telah menyelenggarakan kegiatan pendidikan cukup lama. Madrasah Aliyah Negeri 1 Pidie pada awalnya bernama Sekolah Menengah Islam Atas Swasta (SMI/SMIA) dan kemudian berubah menjadi Madrasah Aliyah Agama Islam Negeri (MAAIN) pada Tahun 1970. Selanjutnya, pada Tahun 1978 MAAIN berubah menjadi MAN I Sigli dan terakhir, pada tanggal 17 November 2016 MAN I Sigli kembali berubah nama menjadi MAN I Pidie berdasarkan Keputusan Menteri Agama Nomor 670 Tahun 2016 Tentang Perubahan Nama Madrasah Aliyah Negeri, Madrasah Tsanawiyah Negeri dan Madrasah Ibtidaiyah Negeri di Provinsi Aceh (Wardinur \& Mutawally, 2019).

27Penulis lahir di Sigli, 26 Agustus 1976, penulis merupakan Kepala Madrasah Aliyah Negeri 1 Pidie. Penulis menyelesaikan gelar Sarjana Agama di STIT Al-Hilal Sigli (1999), gelar Magister Hukum diselesaikan di Universitas Muhammadiyah Sumatera Utara (2012), dan Saat ini sedan menempuh Pendidikan Doktoral di Universitas Islam Negeri Ar-Raniry Banda Aceh. 
Pada tingkatan Madrasah Aliyah, MAN 1 Pidie merupakan salah satu madrasah yang menjadi unggulan di Kabupaten Pidie. Telah banyak alumni MAN 1 Pidie yang berkiprah di berbagai bidang dan turut memberikan warna dalam kehidupan masyarakat Aceh secara umum. Kiprah MAN 1 Pidie sebagai salah satu madrasah unggulan di Kabupaten Pidie membuat masyarakat mempercayakan putra-putri mereka untuk belajar di MAN 1 Pidie. Hal ini dibuktikan dengan meningkatnya minat peserta didik dan orang tua untuk bergabung di MAN 1 Pidie. Kondisi ini juga dipengaruhi oleh beragam agenda dan kegiatan yang di ikuti oleh siswa MAN 1 Pidie pada Event lokal hingga nasional. Namun kondisi ini tampak mengalami penurunan pada tiga tahun terakhir yaitu periode 2019-2021 di mana jumlah siswa yang mendaftarkan diri ke MAN 1 Pidie terus menurun. Pada periode 2016-2018, jumlah kelas untuk siswa baru mencapai sepuluh lokal dan banyak siswa yang meraih prestasi ditingkat lokal dan nasional seperti juara KSM, Video Dokumenter, dan beragam kegiatan olahraga lainnya. Namun data prestasi siswa tersebut kian menurun pada tiga tahun terakhir dan berbanding lurus dengan penurunan jumlah siswa yang mendaftarkan diri ke MAN 1 Pidie.

Pada periode 2019-2021, jumlah pendaftar siswa baru ke MAN 1 Pidie hanya mencapai 300-400 orang, dan jumlah lokal untuk siswa baru hanya delapan lokal/kelas. Kondisi ini tentu tidak disebabkan oleh faktor tunggal, tetapi dipengaruhi oleh beragam kondisi. Salah satu kondisi nyata yang berbanding lurus dengan kurangnya minat siswa melanjutkan jenjang pendidikan di MAN 1 Pidie adalah menurunnya prestasi siswa MAN 1 Pidie di berbagai level kegiatan. Termasuk persentase siswa yang lolos jalur 
undangan atau jalur SNMPTN. Bahkan pada tahun 2019, seluruh siswa MAN 1 Pidie gagal mengikuti SNMPTN akibat kesalahan teknis dan administrasi. Kemudian, kondisi pandemi Covid-19 yang melanda juga semakin memperparah kondisi tersebut karena seluruh kegiatan pembelajaran dan agenda-agenda penting yang telah direncanakan terpaksa harus ditunda dan disesuaikan dengan kondisi pandemi. Siswa terpaksa harus melangsungkan kegiatan pembelajaran dari rumah dengan sistem daring dan minim interaksi langsung dengan guru.

\section{Pandemi Covid-19: Tantangan dan Peluang}

Kondisi pandemi yang terus berlangsung tahun 2021 membuat kegiatan pembelajaran menjadi semakin tidak efektif. Demikian pula dengan berbagai kegiatan siswa yang juga terbengkalai. Menurut Iriansyah (2020) untuk mengatasi permasalahan pendidikan diperlukan upaya inovasi dan pembaharuan karena pemecahan masalahmasalah pendidikan yang sangat kompleks tidak efektif lagi dilakukan pendekatan yang konvensional. Melihat kondisi dan permasalahan yang terjadi di MAN 1 Pidie, berbagai upaya kemudian coba dilakukan. Terutama untuk mengangkat kembali nama MAN 1 Pidie sebagai salah satu Madrasah Unggulan dan mendorong agar orang tua tertarik untuk menyekolahkan putra-putri mereka ke MAN 1 Pidie.

Kondisi pandemi yang tidak kunjung usai dan pamor MAN 1 Pidie yang mulai meredup menuntut adanya inovasi, baik dari sisi pembelajaran maupun dari sisi pengelolaan madrasah. Seiring dengan usaha yang dilakukan oleh Kepala Madrasah, Komite, Dewan Guru, dan Pengawas, kementerian agama kemudian meluncurkan program Madrasah Inovasi. Bak gayung bersambut, program Madrasah Inovasi tersebut semakin menguatkan upaya dan 
usaha yang telah dilakukan untuk menjadikan di MAN 1 Pidie sebagai salah satu madrasah unggulan di Kabupaten Pidie.

Pandemi Covid-19 memang telah mengubah semua kegiatan pendidikan di MAN 1 Pidie. Namun kondisi ini tidak sepenuhnya merugikan karena pada dasarnya segala sesuatu memiliki dua kutub, positif dan negatif. Demikian pula dengan kondisi pandemi Covid-19 yang menjadi peluang tersendiri bagi MAN 1 Pidie. Kondisi perekonomian yang tidak stabil ada masa pandemi ini membuat sebagian besar masyarakat terganggu secara ekonomi. Begitu pula dengan siswa-siswi MAN 1 Pidie. Banyak keluarga siswa yang terdampak langsung oleh kondisi pandemi. Mereka kehilangan pekerjaan dan terpaksa harus bertahan di rumah agar terhindar dari infeksi Covid-19.

Ketika pembelajaran tatap muka secara terbatas sesuai aturan protokol kesehatan diberlakukan. Muncul peluang bagi MAN 1 Pidie untuk berkontribusi secara ekonomi kepada keluarga siswa yang terdampak akibat Pandemi. Dengan jumlah siswa yang mencapai 750 orang, MAN 1 Pidie berpeluang memberikan bantuan kepada keluarga siswa yang terdampak Covid-19 secara ekonomi. Dengan asumsi setiap siswa memberikan sedekah minimal Rp. 1000,- setiap minggu, maka MAN 1 Pidie berpeluang memberikan sumbangan sembako pada dua keluarga siswa yang kesulitan secara ekonomi. Setelah melewati beberapa pertimbangan dan juga diskusi bersama dewan guru dan juga komite madrasah, Program MAN 1 Pidie peduli berbagi kemudian secara resmi diluncurkan. Peluncuran program ini sekaligus menjadi wadah dan peluang promosi MAN 1 Pidie agar dapat kembali dikenal secara luas dan 
berkontribusi nyata pada usaha meringankan beban ekonomi keluarga siswa terdampak Covid-19.

Tentunya, program MAN 1 Pidie peduli berbagi bukan satu-satunya program yang di luncurkan pasca pandemi atau ketika pembelajaran tatap muka kembali diperbolehkan. Namun bersamaan dengan program MAN 1 Pidie peduli berbagai, diluncurkan pula beberapa program lain. Sebagai strategi pemecahan masalah yang dihadapi MAN 1 Pidie, Kepala Madrasah bersama Komite, Pengawas, dan Dewan Guru meluncurkan beberapa program unggulan yang kemudian menjadi solusi untuk mengangkat dan mempromosikan MAN 1 Pidie kepada masyarakat serta mendorong lahirnya siswa-siswi MAN 1 Pidie yang berprestasi sesuai dengan Visi Misi madrasah. Pada sisi praksisnya, program ini dimanifestasikan ke dalam beberapa program unggulan madrasah yaitu program Kelas Unggul yang terdiri dari Kelas Unggul Sains, Agama, Bahasa, dan Keterampilan. Kelas Ekstrakurikuler yang terdiri dari Karya Tulis Ilmiah, Jurnalistik, Olahraga, PIKR, Rohis, Seni, Pramuka, Paskibraka dan UKS.

\section{Gerakan MAN 1 Pidie Peduli Berbagi}

Gerakan MAN 1 Pidie peduli berbagi merupakan program unggulan yang diperuntukkan bagi siswa MAN 1 Pidie yang kurang mampu. Kegiatan ini dilaksanakan setiap hari Jumat yang dimulai dengan pembacaan Surah Yasin secara berjamaah oleh seluruh siswa dan Guru MAN 1 Pidie. Setelah pembacaan Yasin, siswa dan guru memberikan sedekah seikhlasnya pada kotak amal yang telah disediakan. Hasil sedekah tersebut kemudian disalurkan kepada ,keluarga siswa MAN 1 Pidie yang kurang mampu secara ekonomi dengan cara mengunjungi keluarga dan memberikan paket sembako. Gerakan ini diharapkan dapat 
meringankan beban ekonomi keluarga siswa MAN 1 Pidie yang kurang mampu sekaligus sebagai bentuk kampanye sosial MAN 1 Pidie agar lebih dikenal secara luas.

Program ini telah berjalan sejak awal tahun pelajaran baru 2021-2022 dan sudah berhasil menjangkau puluhan keluarga yang tidak mampu. Program ini berhasil mendapatkan sambutan baik dari semua pihak dan program ini sangat potensial karena jumlah siswa MAN 1 Pidie yang cukup besar yaitu 750-an siswa berpotensi memberikan sedekah setiap minggu untuk dua keluarga yang tidak mampu. Program ini kemudian berhasil menginspirasi beberapa madrasah lainnya di Kabupaten Pidie untuk ikut melaksanakan gerakan peduli berbagai dilingkungan madrasah mereka masing-masing.

Gerakan MAN 1 Pidie peduli berbagai merupakan program yang paling jelas hasilnya karena dapat langsung dirasakan oleh penerima manfaat dari program ini. Sejak pertama kali dilaksanakan pada awal tahun ajaran baru 2021-2022 program ini telah berhasil menjangkau puluhan keluarga tidak mampu dari kalangan siswa MAN 1 Pidie. Program ini juga berhasil membuat nama MAN 1 Pidie semakin dikenal oleh masyarakat Kabupaten Pidie. Hasil nyata lainnya yang berhasil diraih adalah menginspirasi beberapa lembaga pendidikan di Kabupaten Pidie untuk melakukan kegiatan serupa demi meringankan perekonomian keluarga tidak mampu yang ada di Kabupaten Pidie.

Ide yang melahirkan program MAN 1 Pidie peduli berbagi tidak terlepas dari kondisi pandemi yang terjadi. Kesulitan ekonomi akibat terganggunya seluruh aktivitas dan kegiatan masyarakat akibat kondisi pandemi membuat pihak madrasah berusaha mencari solusi agar siswa dapat 
terus bersekolah, dan perekonomian keluarga mereka dapat dibantu. Program ini kemudian menjadi jawaban. Hingga saat ini kegiatan pemberian bantuan sembako hasil sedekah siswa MAN 1 Pidie terus berlanjut. Bahkan hingga dapat menyasar keluarga lain di luar keluarga siswa MAN 1 Pidie yaitu warga dilingkungan madrasah yang terdampak pandemi. Kegiatan ini sekaligus menjadi bentuk kontribusi nyata MAN 1 Pidie pada masyarakat yang berada dilingkungan Madrasah. Pelan tapi pasti, gaung MAN 1 Pidie kembali terdengar dan mendapatkan citra positif dari masyarakat.

\section{Penutup}

Setiap peristiwa yang terjadi selalu hadir bersama ragam dimensi, dari yang paling positif hingga yang negatif. Namun kembali lagi, suatu kejadian akan memiliki makna positif maupun negatif sangatlah bergantung pada cara menyikapinya. Demikian pula dengan kondisi pandemi Covid-19 yang kemudian direspons secara positif oleh MAN 1 Pidie. Jumlah siswa yang cukup besar memberikan peluang bagi MAN 1 Pidie untuk berkontribusi secara nyata pada keluarga siswa dan masyarakat sekitar melalui gerakan MAN 1 Pidie peduli berbagi. Meski kondisi ini telah ada sejak lama, namun peluang untuk memunculkan gerakan peduli berbagi baru tampak ketika pandemi mengganggu perekonomian masyarakat. Artinya, kondisi pandemi telah berhasil membuka dan memberikan kesempatan kepada MAN 1 Pidie untuk sampai pada pemikiran yang demikian. Sehingga tidak berlebihan kemudian jika kondisi pandemi "berhasil" mendorong lahirnya inovasi di MAN 1 Pidie. 
Menyongsong PTMT Pada Dunia Pendidikan 


\title{
LITERASI SEBAGAI TRANSPORMASI PENINGKATKAN MINAT BACA
}

\author{
Natalia Peni, S.Si., M.Pd.28 \\ Universitas Flores
}

"Adanya tanam baca masyarakat, sangat membantu dinas pendidikan dan kebudayaan sub bidang pendidikan nonformal dalam upaya membrantas angka buta aksara"

I

nformasi dapat di peroleh dalam hidup seseorang lewat membaca, dimana harus di mulai dari lingkungan keluarga, sekolah dan masyarkat. Indonesia dalam sistem peradapan dunia dikenal sebagai bangsa yang lebih dorninan memiliki budaya lisan- tutur lisan bukan budaya baca tulis. Budaya literasi ( baca, tulis dan hitung) baru dikenal bangsa kita saat dijajah oleh bangsa penjajah (kolonial) seperti Portugis, Belanda, Jnggris dan Jepang. Satu berkah yang ditanamkan oleh penjajah adalah budaya Literasi. Bangsa kolonial rnenjajah bangsa kita dengan menanamkan budaya literasi melalui lembaga pendidikan formal dan non formal.

Selama berabad-abad suku-suku (etnis) yang menghuni kawasan Nusantara sebelum kemerdekaan

28Penulis Lahir pada Leuwalang Kabupaten Lembata pada tanggal 27 Juli 1983. Menempuh pendidikan Sarjana pada Universitas Widya Mandira Kupang pada tahun 2008 Progran Studi Kimia dan Pendidikan Pascasarjana di Universitas Negeri Surabaya Program Studi Pendidikan Sains Konsentrasi Kimia. Saat ini sebagai Dosen di Universitas Flores Ende mengampu Mata Kuliah Kimia Pada Program Studi Pendidikan Matematika Fakultas Keguruan dan Ilmu Pendidikan Universitas Flores. 
mulai belajar budaya baca tulis dan berhitung melalui pendidikan formal kendati adanya diskriminasi.. Nmaun melalui lietrasi pada masa ke masa dan menghasilkan Sumber Daya Manusi yang unggul dan berkualitas. Hasil pendiclikan formal di lembaga pendidikan mulai dari jenjang PAUD, SD, SMP, SMA hingga Perguruan Tinggi diperkuat-didukung pula oleh pendidikan non formal di lingkugan keluarga dan masyarakat.

Pasca kemerdekaan Bangsa Indonesia, pemerintah Republik Indonesia mulai rnernprioritaskan pembangunan bidang pendidikan, kesehatan, ekonomi, sosial, budaya, agama, politik dan keamanan.. Bidangbidang srategis tersebut dibangun dengan peraturan dan perundang-undangan yang dipatuhi dan dilaksanakan secara konsisten dan bertanggungjawab oleh semua warga masyarakat demi tercapainya kemandirian.

Rendahnya tingkat literasi ini tentunya akan mempengaruhi tingkat pengetahuan masyarakat terhadap perkembangan Ilmu Pengetahuan dan Teknologi (IPTEK S). Oleh karena itu butuh dukungan dan kerjasama dari pihak stakeholder internal maupun eksternal. Selain itu juga perkembangan IPTEK akan memberikan dampak negatif dan menjadi persoalan serius bila tidak ada kerjasama antara stakeholder dalam melakukan literasi baik pada keluarga, sebagai dasar dari pendidikan seseorang, sekolah dan masyarakat guna meningkatkan minat baca.

Belajar kegagalan bangsa kita membangun budaya literasi dari masa ke masa sebagaimana digambarkan secara singkat di atas dan belajar dari keunggulan tokohtokoh dunia terutama pendiri bangsa kita Soekamo, Hana, Ki Hajar Dewantoro ( bapak pendidikan Nasional), mari 
kita menghidupkan kembali revitalisasi budaya literasi dalam spirit gotong royong, warisan yang luhur dari para leluhur bangsa kita. Mari dalam gerakan bersama kita mendedikasikan nilai-nilai yang ada dalam budaya gotong royong menjadikan budaya baca tulis dan berhitung serta enam (6) literasi dasar untuk menghidupkan kembali secara nyata di tengah masyarakat komteperor pandemi Covid 19.

Hasil survei UNESCO pada tahun 2020 menyatakan bahwa minat baca masyarakat Indonesia sangat rendah. Dengan demikian perlu gerakan literasi untuk mengembalikan minat baca masyarakat Indonesia karena peringkat tersebut mengancam kemajuan dan kemajemukan bangsa kita. Data ini menunjukkan bahwa perlu ada langkah awal yang harus dibangun di mulai dari literasi membaca, hal ini karena dengan membaca sangat dengan pasti literasi dasar lainnya akan mulai terlatih. Peningkatan budaya literasi harus di program secara baik oleh pemerintah, lembaga swadaya masyarakat, Taman Baca Mayarakat, Lembaga Pendidikan dan para pemerhatian bidang pendidikan untuk mrnjadikan literasi sebagai sebuah aktivitas positif yang akan membawa perubahan bagi bangsai ini.

Kabupaten Ende merupakan salah satu kabupaten di Provinsi Nusa Tenggara Timur yang yang berdasarkan data statik jumlah minat baca sangat rendah karena masih tingginya angka buta aksara. Berdasarkan data tersebut salah satu strategi yang telah dirintis di Bumi Lahirnya Pancasila yakni pada bulan Oktober 2021 meluncurkan Gerakan Indonesia Membaca (GIM) di tingkat kabupaten Ende yang diprakarsasi oleh Direktorat Pendidikan Masyarakat dan Pendidikan Khusus (PMPK) bersama 
Pemerintah Kabupaten Ende dengan tekat yang sama agar dapat meningkatkan minat baca di Kabupaten Ende.

Minat baca adalah kebiasaaan membaca berdasarkan waktu yang telah di atur secar efektif dan efisien berdasarkan kesukaan seseorang. Upaya untuk meningkatkan minat baca harus dimulai dengan 3 jenis literasi yakni literasi keluarga, sekolah dan masyarakat. Literasi keluarga merupakan hasil perpaduan program satuan pendidikan dan keluarga sebagai ikwan. Literasi keluarga dapat dilakukan dalam bentuk 1) menyediakan pojok baca keluarga, 2) orang tua membaca satu buku kepada anak sebelum tidur, 3) memberikan pelatihan kepada calon ibu pada waktu hamil tentang cara membaca yang baik untuk anak, 4) 10 menit membaca sebelum bermain, 5) setiap berpergian tugas orang tua selalu membawa buah tangan untuk anak dama bentuk buku.

Literasi sekolah merupakan salah satu upaya meningkatkan minat baca warga sekolah yang terdiri dari guru, siswa, orang tua dan waraga masyarakat. Gerak literasi di sekolah dapat dilakukan dengan cara 1) 10 menit membaca sebelum jam pembelajaran di mulai, 2) menyediakan pojok baca di setiap ruang kelas dengan memamerkan buku -buku yang menarik, 3) menambah jumlah bahan bacaan di perpustakaan sekolah, 4) meningkatan keterampilan para tenaga perpustakaa, 5) anak yang berprestasi di beri hadiah buku, 6) siswa dan guru yang terlambat datang ke sekolah di berikan saksi keesokkan harinya membawa 1 buah buku dan ditempatkan di perpustakaan sebagai upaya meningkatkan jumlah bacaan di perpustakaan sekolah.

Literasi masyarakat yang dilaksanakan lingkungan masyarakat dengan membuka taman baca masyarakat. 
Untuk mendukung berlanjutan program literasi masyarakat saat ini Direktorat Pendidikan Masyarakat dan Pendidikan Khusus (PMPK) bersama Pemerintah Kabupaten dan Kota untuk membentuk Taman Baca Masyarakat (TBM) sebagai salah satu solusi agar literasi dimasyarakat tercapai. Provinsi Nusa Tenggara Timur (NTT) sekarang telah membentuk Forum Taman Baca Masyarakat (FTBM). Tugas dari forum ini adalah memediasi pembentukan Forum Taman Baca Masyarakat disetiap Kabupaten atau Kota di Provinsi Nusa Tenggara Timur. Taman baca masyarakat dibuka diberbagai desa kelurahan dengan tujuan mendekatkan pelayanan kepada masyarakat agar mudah mengakses bahan bacaan untuk mendukung literasi keluarga dan sekolah.

Kabupaten Ende telah memiliki ketua forum taman baca masyarakat sejak tahun 2019. Dengan adanya ketua forum di tingkat kabupaten, hal ini berdampak positif dimana telah terbentuk 20 Desa dan Kelurahan di Kabupaten Ende yang telah memiliki taman baca masyarakat yang diprakarsa oleh masyarakat dari alokasi dana desa dan kelurahan. Aktivitas yang telah dilakukan oleh FTBM masyarakat di kabupaten Ende yakni memberikan pelatihan peningkatan kapasitas pengelola taman baca, pelatihan peningkatkan keterampilan mendongeng bagi para pengiat literasi, workshop membaca lantang pagi para penggiat, workshop pemgolahan sampah berbasis masyarakat, workshop menulis bagi para penggiat literasi, dan anak-anak dampingan TBM, workshop literasi pengelolaan keuangan keluarga bagi para ibu, melakukan kegiatan sosial di panti asuhan dengan melakukan kegiatan literasi baca tulis bagi anak pantiasuhan. 
Pelatihan peningkatan kapasitasi pengelola taman baca dengan tujuan agar taman baca yang baru di rintis di setiap desa dan kelurahan bertahan kokoh untuk menyediakan bahan bacaan yang dibutuhkan masyarakat, para pengelola taman baca mampu menetapkan manajemen pengelolaan dan pelayanan yang baik bagi para penggunjung. Pelatihan peningkatkan keterampilan mendongeng bagi para pengiat literasi, selanjuntnya di transferkan pengetahuan keterampilan mendongeng dan workshop membaca lantang pagi para penggiat bagi para ibu sebagai sarana peningkatan pengetahuan seorang ibu dalam mengubah pola asuh agar anak termotivasi untuk mendengar bacaan yang di bacakan oleh ibunya pada waktu menjelang tidur, waktu melakukan wisata keluarga serta membantu anak untuk keluar dari zona nyaman akan akan game online, film anak-anak, kurangi waktu bermain, dan hal-hal yang tidak pantas bagi seorang anak.

Tugas lain lagi yang sedang dilakukan oleh ketua FTBM dan para pengurus kabupaten Ende yakni memediasi para pengambil kebijakan agar apat mengalokasikan anggaran untuk pemberdayaan masyarakat tentang manfaat dari adanya taman baca masyarakat, penambahan sarana dan prasarana taman baca, penyediaan bahan bacaan untuk memenuhi kebutuhan masyarakat. Hasil lain juga adalah dari 20 TBM yang di bentuk sepuluh (10) TBM teah memiliki izin pendirian sebagai legalitasi dalam melakukan aktivitas literasi. Berdasarkan data hasil observasidi peroleh informasi bahwa dengan adanya tanam baca masyarakat, sangat membantu dinas pendidikan dan kebudayaan sub bidang pendidikan nonformal dalam upaya membrantas angka buta aksara di kabupaten. Dalam aktivitas gerakan literasi di Kabupaten Ende Forum Taman 
Baca Masyarakat disponsori dalam hal pendanaan dan penyediaan bahan bacaan dan sarana prasarana oleh Dinas Pendidikan dan Kebudayaan Kabupaten Ende, Perpustakaan Daerah Kabupaten Ende, Dinas Komunikasi dan Informasi Kabupaten Ende, dan Perusahaan Listrik Negara. Dari hasil kolaborasi dengan stakeholder diharapakan mampu meningkatkan minat baca masyarakat Kabupaten yang direncanakan akan di nobatkan menjadi Kabupaten Literasi pada Tahun 2022. 
Menyongsong PTMT Pada Dunia Pendidikan 


\title{
MEWUJUDKAN PROFIL PELAJAR PANCASILA \\ PADA PEMBELAJARAN TATAP MUKA \\ TERBATAS PASCAPANDEMI MELALUI \\ KEGIATAN PEMBIASAAN
}

\author{
Nur Aniyah, S.Pd.SD 29 \\ SDN Kebondal Mojosari Mojokerto
}

"Kegiatan yang dapat dilakukan untuk mewujudkan profil pelajar Pancasila adalah yang pertama, melalui keteladanan guru; kedua, pembiasaan siswa dan ketiga, penerapan budaya sekolah"

Dancasila adalah perjanjian luhur para pendiri bangsa yang wajib kita jaga. Dimana di dalamnya terdapat corak asli watak rakyat Indonesia. Pelajar Pancasila adalah perwujudan pelajar Indonesia yang berperilaku sesuai nilainilai Pancasila dan berwawasan global yang tercermin dalam enam ciri utama yaitu: beriman, bertaqwa kepada Tuhan YME dan berakhlak mulia, berkebhinekaan global, bergotong royong, mandiri, bernalar kritis, dan kreatif.

Profil Pelajar Pancasila yang pertama adalah beriman, bertaqwa kepada Tuhan YME, yaitu pelajar yang memahami ajaran agama dan menerapkan pemahamannya dalam kehidupan sehari- hari. Hal tersebut dapat tercermin dalam

${ }^{29}$ Penulis lahir di Mojokerto, 05 Mei 1985, penulis merupakan Guru di SDN Kebondalem Kec. Mojosari Kab. Mojokerto, penulis menyelesaikan gelar Sarjana Pendidikan Sekolah Dasar di Universitas Terbuka UPBJJ Surabaya (2009) 
sikap dan akhlak yang terpuji, baik akhlak dalam beragama, akhlak pribadi, akhlak kepada sesama manusia, akhlak kepada alam dan akhlak dalam bernegara.

Profil Pelajar Pancasila yang kedua adalah berkebhinekaan global, yaitu pelajar yang mempertahankan budaya luhur, lokalitas dan identitasnya dan tetap berpikiran terbuka dalam berinteraksi dengan budaya lain, sehingga menumbuhkan rasa saling menghargai dan kemungkinan terbentuknya budaya baru yang positif dan tidak bertentangan dengan budaya luhur bangsa. Hal tersebut dapat tercermin dalam sikap mengenal dan menghargai budaya, kemampuan berkomunikasi dan berinteraksi dengan sesama, dan refleksi dan tanggung jawab terhadap pengalaman kebhinekaan.

Profil Pelajar Pancasila yang ketiga adalah bergotongroyong, yaitu pelajar yang memiliki kemampuan gotong royong, melakukan kegiatan bersama- sama dengan suka rela agar kegiatan yang dilaksanakan dapat berjalan lancar, mudah dan ringan. Hal tersebut dapat tercermin dalam perilaku suka berkolaborasi, memiliki kepedulian terhadap lingkungan dan suka berbagi kepada sesama.

Profil Pelajar Pancasila yang keempat adalah mandiri, yaitu pelajar yang memiliki tanggung jawab atas proses dan hasil belajarnya. Hal tersebut dapat tercermin dalam perilaku kesadaran akan diri dan situasi yang dihadapi dan kemampuan mengatur dirinya sendiri.

Profil Pelajar Pancasila yang kelima adalah bernalar kritis, yaitu pelajar yang memiliki kemampuan memproses informasi baik secara kualitatif maupun kuantitatif, membangun keterkaitan antara berbagai informasi yang diperoleh, lalu menganalisisnya, mengevaluasi dan menyimpulkannya. Hal tersebut dapat tercermin dalam 
perilaku mengolah informasi dan gagasan, menalar dan merefleksi dan mengambil keputusan.

Profil Pelajar Pancasila yang keenam adalah kreatif, yaitu pelajar yang memiliki perilaku mampu memodifikasi dan menghasilkan sesuatu yang orisinal, bermakna, bermanfaat dan berdampak. Hal tersebut tercermin dalam perilaku menghasilkan gagasan, karya dan tindakan yang orisinal.

Bagaimana mewujudkan keenam profil tersebut dalam pembelajaran tatap muka terbatas pascapandemi saat ini? Untuk mewujudkan Profil Pelajar Pancasila tidaklah mudah seperti membalikkan telapak tangan. Tetapi sebagai pendidik, kita harus selalu mengupayakannya demi masa depan anak- anak kita. Hal pertama yang harus kita lakukan adalah melalui keteladanan. Sebagai guru kita harus lebih banyak memberi contoh daripada hanya sekedar memberi perintah. Kita harus memulai dari diri kita sendiri terlebih dahulu. Bagaimana ketaatan kita terhadap Tuhan YME, bagaimana cara kita membangun kerja sama dengan semua warga sekolah, bagaimana sikap kita saat menghadapi masalah, kekreatifan kita dalam mengajar di kelas, cara berpakaian, sopan santun, menjaga kebersihan dan lain sebagaianya, semua tingkah laku kita akan direkam anak didik kita. Siswa sudah pandai menilai kepribadian dan kebiasaan masing- masing guru. Jadi sebelum kita menjadi guru yang Pancasila jangan harap siswa kita berjiwa Pancasila. Jika kita menginginkan murid kita taat beribadah, maka kita sendiri juga harus taat beribadah. Jika kita menginginkan murid kita disiplin, maka kita sendiri juga harus disiplin. Jika ingin murid sopan santun, kita juga harus sopan santun. Jika ingin murid peduli terhadap lingkungan, maka kita harus tunjukkan kepedulian kita 
terhadap lingkungan. Jika kita ingin murid kita suka bergotong- royong, maka kita harus contohkan bergotong royong dengan warga sekolah.

Selain keteladanan seorang guru, upaya yang dapat dilakukan untuk mewujudkan profil pelajar Pancasila adalah melalui kegiatan pembiasaan dan budaya sekolah baik sebelum pembelajaran, saat pembelajaran berlangsung maupun setelah pembelajaran selesai. Sampai kebiasaan itu dibawa siswa pulang ke rumah masing- masing dan diterapkan dalam kehidupan sehari- hari. Karena pada pembelajaran tatap muka terbatas ini kegiatan pembelajaran hanya berlangsung 3 jam saja, maka dalam waktu sesingkat itu sebagai guru kita harus optimal dalam pengajaran sekaligus pembentukan karakter siswa.

Adapun kegiatan pembiasaan yang dapat diterapkan siswa di sekolah di antaranya adalah budaya $5 \mathrm{~S}$ (senyum, salam, sapa, sopan dan santun). Sebagai contoh yang sudah diterapkan di SDN Kebondalem Kecamatan Mojosari Kabupaten Mojokerto adalah berpamitan kepada orang tua saat berangkat sekolah dan selalu mencium tangan untuk meminta doa. Mengucapkan salam kepada Bapak/ Ibu Guru di sekolah, menyapa saat bertemu, meminta izin jika tidak dapat masuk sekolah, dan disiplin mematuhi peraturan kelas.

Kebiasaan yang sesuai dengan profil pelajar pancasila yang pertama adalah selalu berdo'a sebelum dan sesudah belajar, membaca surat- surat pendek sebelum belajar dan menghormati teman yang berbeda agama. Aktif mengikuti acara peringatan hari besar keagaamaan. Karena terdapat beberapa siswa yang nonmuslim maka terdapat peringatan hari Natal juga di bulan Desember di sekolah kami. Dan 
yang beragama muslim dapat menghormatinya meskipun minoritas.

Sedangkan kebiasaan dan budaya sekolah yang sudah sesuai dengan profil pelajar Pancasila yang kedua adalah berpikir global, bertindak lokal. Seminggu sekali siswa harus memakai bahasa Jawa dan bahasa Inggris secara bergantian dalam percakapan dengan semua warga sekolah. Misal Sabtu ini wajib berbahasa Jawa, Sabtu depannya wajib berbahasa Inggris. Selain itu kita juga tetap melestarikan kesenian daerah berupa ekstrakurikuler karawitan dan memakai batik pada hari Rabu dan Kamis. Di sekolah kami juga terdapat siswa putra- putri prajurit TNI AD yang berasal dari luar daerah seperti dari Ambon, Sumatera, dan lain- lain. Siswa sudah terbiasa saling menghormati budaya masing- masing.

Adapun kegiatan pembiasaan yang sesuai dengan profil pelajar Pancasila yang ketiga adalah gotong royong di semua kegiatan. Pengelolaan siswa di dalam kelas juga selalu ada kegiatan diskusi secara berkelompok agar bekerja sama dan berkolaborasi dalam menyelesaikan tugas. Kegiatan di luar pembelajaran juga sudah menjadi budaya warga sekolah selalu bekerja bakti membersihkan lingkungan, menghias kelas, menanam bunga di taman atau gotong royong iuran sukarela paguyuban wali murid untuk memperbaiki gedung yang rusak.

Contoh kebiasaan siswa yang sesuai dengan profil pelajar Pancasila yang keempat adalah semua siswa mandiri dalam aktivitas di kelas misal membaca surat- surat pendek sebelum pelajaran dimulai meskipun guru belum masuk kelas, siswa sudah mempunyai inisiatif memulai kegiatan sendiri karena sudah ada petugas piket yang merangkap sebagai pemimpin doa, dirijen lagu Indonesia Raya. Setiap 
hari bergiliran siswa laki- laki memimpin do'a dan siswa perempuan menjadi dirijen. Selain itu siswa juga mandiri saat mengerjakan ulangan. Siswa juga dapat menentukan ekstrakurikuler yang sesuai dengan bakat yang dimiliki.

Kegiatan pembiasaan siswa yang sesuai dengan profil pelajar Pancasila yang kelima adalah siswa terbiasa bertanya tentang pelajaran atau memprotes hal yang tidak tepat menurutnya. Misal ketika guru salah menghitung, mereka berani meminta izin memberikan pendapatnya. Kegiatan diskusi kelompok menyelesaikan LK juga dapat melatih mereka untuk selalu bernalar kritis dalam memecahkan masalah. Seperti dalam memberikan alternatif jawaban atau membuat mind maping suatu topik bahasan.

Sedangkan kegiatan yang dapat diterapkan sesuai profil pelajar Pancasila yang keenam adalah dalam setiap kegiatan pembelajaran selalu ada tugas yang memunculkan kreativitas siswa. Misalnya membuat poster, membuat batik, membuat mading kelas, membuat patung, menciptakan lirik lagu sendiri sesuai nada asli lagu, membuat kreasi hiasan jendela atau sudut baca, membuat alat peraga bangun ruang, membuat pot bunga dan lain sebagainya.

Keenam profil pelajar pancasila tersebut akan dapat terwujud jika sebagai guru kita juga berjiwa Pancasila. Menjunjung tinggi warisan luhur pendiri bangsa dan menerapkannya dalam sikap di kehidupan sehari- hari. Taqwa kepada Tuhan Yang Maha Esa, berwawasan global, gotong royong, bernalar kritis, mandiri dan kreatif. Intinya, baik pembelajarannya daring, tatap muka terbatas maupun full tatap muka kegiatan yang dapat dilakukan untuk mewujudkan profil pelajar Pancasila adalah yang pertama, 
Rita Meutia, dkk.

melalui keteladanan guru; kedua, pembiasaan siswa dan ketiga, penerapan budaya sekolah. 
Menyongsong PTMT Pada Dunia Pendidikan 


\title{
EFEKTIVITAS VAKSINASI SISWA \\ DALAM MENGHADAPI PTMPT \\ PASCAPANDEMI COVID I9
}

\section{Linda Arisanty, S.Pd. ${ }^{30}$ \\ MAN Sumenep}

\begin{abstract}
“Vaksinasi untuk siswa sangat penting mengingat pekembangan ilmu pengetahuan bergerak maju secara dinamis"
\end{abstract}

\section{Pendahuluan}

Dandemi covid 19 sudah dua tahunan melanda di Indonesia. Banyak kegiatan masyarakat di berbagai sektor berusaha beradaptasi dengan tatanan kehidupan normal baru. Pemerintah juga mengambil langkah-langkah dan kebijakan di beberapa bidang untuk membantu mengurangi beban masyarakat dalam menghadapi pandemi.

Berbagai kegiatan dan pergerakan masyarakat dibatasi, dalam rangka menekan dan mengurangi penyebaran virus covid 19. Kegiatan yang mengharuskan bertatap muka digantikan dengan jejaring online, perkantoran dan juga menerapkan bekerja dari rumah atau WFH (Work From Home). Perusahaan banyak yang merumahkan sebagian dari karyawannya sebagai imbas pandemi. Dunia

30Penulis lahir di Sumenep, 06 Maret 1982, penulis merupakan guru pelajaran Bahasa Indonesia di MAN Sumenep, penulis menyelesaikan gelar Sarjana Pendidikan Bahasa dan Sastra Indonesia di FKIP- Universitas Jember (2006) 
pendidikan, tak luput dari efek pandemi. Menteri Pendidikan dan Kebudayaan, Nadien Makarim pun memutuskan pembelajaran daring atau belajar dari rumah bagi para siswa, dengan mengeluarkan ketetapan melalui Surat Edaran Mendikbud Nomor 4 Tahun 2020.

Pendidikan adalah salah satu faktor yang terdampak covid 19, dimana-mana semua pembelajaran dilakukan secara daring (Muhajir, 2020). Cara ini ditempuh untuk menekan penyebaran virus Covid di kalangan anak-anak. Penerapan pembelajaran daring di kota besar hampir tidak mengalami kendala, karena tersedianya akses internet yang memadai. Namun, sebaliknya, di pelosok daerah, yang akses internet yang rendah,banyak siswa yang mengalami kesulitan menerima pelajaran, banyak juga orang tua siswa yang kurang paham penggunaan telepon pintar.

Rencana pengadaan vaksin akhirnya dimulai, pemerintah dalam hal ini Kementerian Kesehatan dan kementerian terkait membuat perencanaan pembiayaan pengadaan, uji klinis, serta pengawasan vaksin Covid 19 sebelum sampai ke masyarakat. Pelaksanaan uji klinis didukung oleh perusahaan kesehatan, Fakultas Kedokteran dari universitas ternama, Badan POM serta lembaga penelitian di bawah naungan kementerian Kesehatan.

Vaksin terlebih dahulu dilakukan uji klinis. Proses tersebut antara lain adanya konsep pengembangan zat aktif, pembuatan calon vaksin, metode analisis dan pengujian non-klinis sampai dengan uji klinis, (Rahmi Ningsih, 2020). Banyak sukarelawan yang bersedia menerima suntikan vaksin untuk mengetahui tingkat keamanan, manfaat serta mutu vaksin. Nantinya data yang diperoleh akan menentukan tingkat keberhasilan vaksinasi. Tidak hanya Indonesia yang melakukan uji klinis vaksin, beberapa 
negara juga melakukan uji klinis vaksin untuk segera melaksanakan vaksinasi massal.

Pemerintah juga gencar melakukan sosialisasi pentingnya vaksinasi ini untuk memutus mata rantai penyebaran Covid 19 (Idil Akbar, 2021). Upaya sosialisasi melibatkan MUI terkait isu kehalalan vaksin, juga mengikutsertakan elemen masyarakat seperti tokoh atau sesepuh yang berpengaruh di lingkungannya. Pihak sekolah juga diajak bersosialisasi dalam rangka persiapan PTMPT. Walaupun ada kendala pada saat sosialisasi vaksinasi, adanya penolakan dari kelompok antivaksin. Berita hoax tentang vaksin Covid 19, bahwa vaksin dan obat covid 19 adalah sama. Padahal keduanya memiliki karakter berbeda, vaksin bersifat mencegah sedangkan obat bersifat menyembuhkan. Sangat penting diperhatikan adalah masyarakat lebih terpengaruh berita atau info di media sosial daripada berita di televisi dan surat kabar nasional.

Pengawasan pelaksanaan vaksinasi di seluruh tempat juga sangat penting, seperti tersedianya vaksin, pengeluaraan anggaran, mutu vaksin, sampai pengawasan terhadap efek vaksin yang ditimbulkan bagi setiap orang yang telah disuntik. Semua harus dipersiapkan dengan tepat, sehingga minimal $70 \%$ masyarakat Indonesia dilakukan vaksin agar terbentuk herd imunity (Media Indonesia, 12 Agustus 2020)

Mayoritas siswa maupun orang tua berpendapat bahwasanya pembelajaran daring kurang efektif dibandingkan dengan pembelajaran secara luring (Lisman, Primawati, Waskito, dan Sari, 2021). Orang tua yang sudah memiliki kesibukan tiap harinya seperti bekerja, harus bisa meluangkan waktu untuk mendampingi dan mengontrol belajar anak selama di rumah. Banyak orang tua merasa 
terganggu, terutama ibu rumah tangga yang notabenenya setiap hari sudah disibukkan dengan urusan rumah tangga. Para ibu mengeluh, mereka tidak banyak memiliki pengetahuan yang cukup untuk membantu pembelajaran putra-putrinya. Dampaknya, tugas siswa dikerjakan sebisanya, tingkat emosional berubah drastis, jam belajar yang singkat, serta capaian materi yang sedikit. Di sisi lain, para guru harus pintar-pintar mencari model pembelajaran yang cocok dengan pembelajaran daring. Cara ini harus ditempuh, agar pembelajaran daring tidak terkesan membosankan dan jenuh. Guru dan siswa juga harus menambah pengeluaran ekstra untuk pembelian kuota internet.

Apakah kegiatan bekerja dan belajar melalui jaringan produktif? Apa langkah-langkah pemerintah, dalam hal ini Kementerian Pendidikan dan Kebudayaan beserta kementerian terkait melihat fenomena ini?. Maka dari itu perlu adanya vaksinasi agar pembelajaran siswa siap menghadapi PTMPT.

\section{Pembahasan}

Melihat banyak laporan bahwa pembelajaran kurang efektif, terutama di daerah yang kurang memadai infrastukturnya. Tidak nampak hasil yang yang menggembirakan bagi guru dan siswa. Lintas kementerian melalui 4 (empat) menteri menemukan titik kesepakatan dengan mengeluarkan surat keputusan bersama yang mengatur tentang pembelajaran tatap muka terbatas pascapandemi. Hal ini dilakukan dengan tujuan memenuhi kebutuhan minat belajar siswa yang mulai menurun serta desakan orang yang menginginkan pembelajaran tatap muka. 
Langkah awal pemerintah mempersiapkan PTM adalah menyiapkan sekolah dan para guru. Sekolah harus menyiapkan sarana dan prasana yang sesuai dengan standar protokol kesehatan dari dinas kesehatan dan WHO. Para siswa dan guru harus melaksanakan vaksinasi. Vaksin adalah satu cara pencegahan penyakit yang berfungsi dengan merangsang sistem imuniti badan untuk melindungi dari dari jangkitan penyakit, (Fahmi Hassan, 2021). Vaksinasi dilakukan sebagai salah satu cara untuk meringankan gejala jika terkena penyakit.

Vaksin-vaksin covid 19 sudah menjalani serangkaian penelitian dan uji klinis sebelum sampai ke masyarakat. Usaha ini dilakukan, karena sampai saat ini, belum ditemukannya obat untuk mengobati virus covid 19. Virus corona dapat menyebabkan infeksi saluran pernapasan yang dapat menyebabkan morbiditas dan mortalitas, terutama pada mereka yang immunocompromised atau yang tidak memiliki kekebalan terhadap virus. Virus baru selalu menakutkan karena kita memiliki sedikit atau tidak ada sama sekali kekebalan protektif terhadap tubuh kita dan kita tidak memiliki vaksin (Patel, 2017:35).

Para guru mendapatkan vaksinasi, setelah para nakes mendapatkan dua kali suntikan vaksin. Guru dianggap harus mendapatkan vaksin selanjutnya karena nantinya ketika PTM akan berinteraksi dengan siswanya. Awal mulanya para guru masih takut dan ragu akan keamanan vaksin Covid 19. Setelah BPOM mengumumkan secara resmi bahwa vaksin covid 19 aman untuk tubuh, barulah banyak guru melakukan vaksinasi di pelayanan kesehatan terdekat.

Tahap selanjutnya adalah para vaksinasi untuk siswa usia 12 tahun ke atas. Siswa dianggap penting untuk melakukan vaksinasi, karena ketika PTM banyak 
berinteraksi dengan teman sebaya dan guru. Vaksinasi ini penting bagi siswa, selain perlindungan diri dari dalam tubuh, juga meringankan gejala Covid 19. Prokes 5M yang sudah disosialisasikan sejak pertengahan pandemi tidak selamanya diterapkan secara disiplin. Banyak para siswa yang abai mencuci tangan, berkerumun, lebih-lebih penggunaan masker masih tidak tepat ketika berbicara dengan temannya.

Praktik di lapangan ketika pelaksaanaan vaksinasi siswa, banyak orang tua yang masih keberatan anaknya untuk divaksin. Kultur daerah yang masih awam tentang pentingnya vaksin, serta berita hoax tentang vaksin, menyebabkan minat vaksinasi di siswa masih rendah. Sosialisasi di media cetak dan elektronik terus digalakkan oleh pemerintah agar pembelajaran tatap muka terbatas segera terlaksana.

Vaksin Covid 19 tidak seburuk yang diberitakan oleh sekelompok orang yang dengan sengaja menyebarkan efek vaksin yang buruk tanpa ada bukti yang bisa dipertanggungjawabkan secara ilmiah. Vaksinasi salah satu upaya pemerintah agar kegiatan masyarakat bisa berjalan seperti biasanya. Termasuk kegiatan belajar mengajar di sekolah.

Evaluasi terus dilakukan, kekurangan yang ada pada proses vaksinasi terus dibenahi. Seiring berjalannya waktu, banyak orang tua dan siswa menyadari pentingnya vaksinasi, setelah melihat kasus positif Covid 19 di Indonesia mulai melandai atau menurun. Vaksinasi massal di berbagai tempat di penjuru nusantara mampu menekan dan penambahan pasien positif di tanah air.

Hal ini membuat siswa bersemangat untuk vaksinasi dan menyiapkan diri menyongsong pembelajaran tatap 
muka terbatas. Siswa mulai berbenah diri, menyiapkan peralatan sekolah seperti seragam dan buku pelajaran yang selama ini hanya bertumpuk di meja belajarnya. Perlengkapan wajib baru yang harus dibawa adalah sanitizer dan masker yang wajib dikenakan ketika di dalam kelas. Siswa berharap setelah lengkap dua kali divaksinasi dapat menambah daya tahan tubuh mereka ketika berinteraksi dengan teman di sekolah.

\section{Penutup}

Kegiatan vaksinasi untuk siswa diharapkan dapat meningkatkan semangat siswa untuk segera belajar bersama di sekolah. Pembelajaran tatap muka terbatas pascapandemi sangat efektif dibandingkan dengan pembelajaran daring. Vaksinasi untuk siswa sangat penting mengingat pekembangan ilmu pengetahuan bergerak maju secara dinamis. Dibutuhkan generasi muda normal baru yang mampu menyesuaikan diri menghadapi segala tantangan pascapandemi. Sehingga kelak, kontribusi atau sumbangsih dapat mereka berikan untuk Indonesia tercinta.

\section{Daftar Pustaka}

Akbar, Idil. (2021). Vaksinasi Covid 19 dan Kebijakan Negara: Perspektif Ekonomi Politik: Universitas Padjadjaran Bandung. “Academia Praja” Volume 4 No. 1 Februari 2020 Hassan, Fahmi. (2021). Panduan Ringkas Covid-19 dan Vaksin, (Online) (https://id1lib.org/ireader/16368624). Diakses pada tanggal 04 November 2021.

Lisman, F., Primawati, Waskito, dan Sari, D. Y. (2021). Kelebihan dan Kekurangan Sistem Pembelajaran Daring dari Perspektif Guru dan Siswa di SMK Negeri 2 Payakumbuh Andvantages. Journal Homepage 
Muhajir. (2020). Pembelajaran daring di Era Covid-19: Kesenjangan Digital, Sistem Kompetisi, dan Model Pendidikan yang Manusiawi. Mimikri

Patel, Harsh., Alkhawam, Hassan., Madanieh, Raef., Shah, Niel., Kosmas, Constantine E., and Vittorio, Timothy J. 2017. Aerobic $v s$ anaerobic exercise training effects on the cardiovascular system. World Journal Cardiol. 2017 Feb 26; 9(2): 134-138. Doi: 10.4330/wjc.v9.i2.134

Produksi Vaksin Semakin Dekat, Media Indonesia, 12 Agustus 2020, Hal 1.

Yuningsih, Rahmi. (2020). Uji Klinik Coronovac dan rencana Vaksinasi Covid-19 Massal di Indonesia: Pusat Penelitian Badan Keahlian DPR RI. "Info Singkat: Kajian Singkat Terhadap isu Aktual dan Strategis" Vol. XII No. 16/Puslit/Agustus/2020 


\title{
PROBLEMATIKA KARAKTER SISWA PASCA \\ PANDEMI DALAM PEMBELAJARAN \\ TATAP MUKA TERBATAS
}

\author{
Nurhidayah, SH ${ }^{31}$ \\ SMA Negeri 12 Palembang
}

“Generasi muda yang kehilangan karakter-karakter positif karena pendidikan kita akhirnya didominasi pembelajaran daring yang hanya mengedepankan transfer pengetahuan tanpa penanaman nilai-nilai akhlak"

$\mathrm{M}$ arzuki (2012, hal. 42) menyatakan bahwa pendidikan karakter di sekolah merupakan bagian dari reformasi pendidikan, maka reformasi pendidikan karakter bisa diibaratkan sebagai pohon yang memiliki empat bagian penting, yaitu akar, batang, cabang, dan daun. Akar reformasi adalah landasan filosofis (pijakan) pelaksanaan pendidikan karakter harus jelas dan dipahami oleh masyarakat. Pengintegrasian Pendidikan Karakter dalam Pembelajaran di Sekolah penyelenggara dan pelaku pendidikan. Batang reformasi berupa mandat dari pemerintah selaku penanggung jawab penyelenggara pendidikan nasional. Dalam hal ini standar dan tujuan

31Nurhidayah, SH, lahir di Palembang, 14 Agustus 1976, Menyelesaikan Pendidikan S1 di Fakultas Hukum Jurusan Hukum dan Bisnis Universitas Sriwijaya pada tahun 1999, pada tahun 2002 menyelesaikan Akta IV di Universitas Sriwijaya. Sejak Tahun 2003 bertugas sebagai Guru Sosiologi di SMA Negeri 12 Palembang dan di tahun 2017 menjadi Instruktur Kota dan Guru Inti mata pelajaran Sosiologi. 
dilaksanakannya pendidikan karakter harus jelas, transparan, dan akuntabel. Cabang reformasi berupa manajemen pengelolaan pendidikan karakter, pemberdayaan guru, dan pengelola pendidikan harus ditingkatkan. Sedang daun reformasi adalah adanya keterlibatan orang tua peserta didik dan masyarakat dalam pelaksanaan pendidikan karakter yang didukung pula dengan budaya dan kebiasaan hidup masyarakat yang kondusif yang sekaligus menjadi teladan bagi peserta didik dalam bersikap dan berperilaku sehari-hari.

Fakta yang tak terbantahkan di Indonesia pada bulan Maret 2020 pelajar dan mahasiswa tidak lagi belajar secara tatap muka yang artinya pembelajaran dilaksanakan secara online. siswa atau pelajar sekolah terpaksa melanjutkan pendidikan secara daring atau online dari rumah berakibat banyak masalah baru yang dihadapi. Masalah tersebut dihadapi oleh pihak sekolah sebagai penyelenggara pendidikan, orangtua dan siswanya sendiri. Pembelajaran secara online ini berlangsung lebih dari satu tahun yang berakibat positif bagi proses pembelajaran yaitu beragamnya aplikasi yang dapat digunakan tenaga pengajar dalam proses pembelajaran yang berlangsung semakin kreatif dan beragam. Akibat negatif yang ditimbulkan juga tidak sedikit, siswa terbiasa memegang handphone dan gadget yang memang diperlukan saat belajar daring, apabila tidak ada kontrol dari orangtua hal ini akan sangat berdampak pada keadaan fisik dan mentalnya.

Meskipun secara formal kegiatan pendidikan masih bisa dilakukan secara online, karena siswa tetap harus belajar di rumah, berdampak pada pendidikan karakter dan akhlak mulia selama masa pandemi ini, rasanya menjadi sedikit terabaikan. Sebelumnya, ketika kegiatan pendidikan 
dilakukan di sekolah, pendidikan karakter dilakukan dengan pengawasan langsung dari guru. Kegiatan-kegiatan yang mendukung pendidikan karakter juga bisa dilakukan langsung, secara intensif dan bisa diukur tingkat keberhasilannya. Pendidikan bukan hanya mendidik peserta didiknya menjadi cerdas, tetapi yang utama adalah membangun kepribadiannya agar berakhlak mulia. Di saat ini, ketika kegiatan pendidikan dilakukan secara daring, kebanyakan dalam proses pembelajaran hanya transfer pengetahuan saja, tak ada yang bisa menjamin siswa mendapatkan pendidikan karakter dari kedua orang tua mereka sesuai dengan nilai-nilai yang selama ini diajarkan disekolah.

Berdasarkan pengalaman banyak pengajar yang mengeluhkan partisipasi siswa saat pembelajaran online berlangsung. Ketika pembelajaran dengan aplikasi zoom atau meet, Pengajar kesulitan memastikan apakah siswanya benar benar hadir, aktif dan mengikuti pembelajaran dengan serius. Sering terjadi, dalam pembelajaran online, ada siswa yang sengaja mematikan kamera atau memasang video yang sudah direkam, agar seolah-olah mengikuti proses pembelajaran, namun ternyata mereka melakukan hal lain. Dalam pembelajaran secara online yang waktunya sangat terbatas, pengajar hanya menyampaikan informasi dan paparan tentang materi pelajaran, tanya jawab, quiz dan penugasan yang harus dilakukan oleh siswa. Kadangkala jumlah siswa yang hadir juga tidak seluruh siswa dikelas yang diajar, hal ini menimbulkan, informasi materi tidak tersampaikan seluruhnya. Jadi hampir tidak ada kesempatan tenaga pengajar untuk menanamkan karakter disiplin, akhlak terpuji dan religius kepada siswa 
Sebagai contoh putra kami saat ini melanjutkan pendidikannya di sekolah Islam, yang menekankan pendidikan karakter dengan kegiatan peribadatan seperti sholat wajib dan sunnah secara berjama'ah, atau pengajian Al Quran, otomatis saat ini tidak bisa melakukan kegiatan tersebut, karena siswa-siswa harus belajar di rumah. Memang mungkin saja beberapa sekolah telah membuat mekanisme pelaporan kegiatan ibadah siswa di rumah, berupa foto atau video saat siswa sedang beribadah, namun tetap saja kehadiran guru dan pendidik serta interaksi mereka dengan para siswa secara langsung diperlukan untuk pelaksanaan pendidikan karakter yang lengkap dan menyeluruh.

Ketika pembelajaran secara tatap muka keteladanan para guru dan pendidik yang dilihat dan dirasakan langsung oleh para siswa adalah kunci utama pendidikan karakter di lembaga pendidikan. Siswa dapat melaksanakan proses pembelajaran diiringi dengan penanaman nilai nilai dan budi pekerti yang baik, karena hampir sepanjang waktu pembelajaran dilaksanakan disekolah. Berbanding terbalik dengan keadaan pandemi saat ini siswa hanya belajar secara online dirumah, banyak orang tua yang sibuk bekerja, khususnya diwaktu-waktu pembelajaran daring berlangsung. Tentunya mereka tak bisa mengawasi langsung apa yang dilakukan oleh anak-anak mereka, jika pandemi ini berkelanjutan dan pembelajaran daring dilakukan setahun lebih, generasi muda bangsa ini akan terbiasa dengan berbagai kemudahan-kemudahan yang tak mendidik dan kebiasaan kebiasaan yang terjadi dalam proses belajar secara daring.

Di semester ganjil tahun ini, pemerintah telah memberikan izin kepada pihak sekolah untuk melakukan 
proses belajar secara tetap muka walaupun waktu belajar dan jumlah siswanya dibatasi. Sekolah selama ini sebagai salah satu komponen yang penting untuk melaksanakan nilai-nilai positif agenda pada pengembangan pendidikan karakter pada anak didik di sekolah. Sekolah sebagai tempat kedua untuk melakukan sosialisasi dan pendidikan yang terstruktur dibandingkan dengan kegiatan dirumah yang relatif bersifat insidental, sehingga sekolah memiliki peran yang penting untuk mewujudkan pemberdayaan kepada para peserta didik menjadi warga sekolah yang memiliki kepribadian yang baik sesuai dengan nilai-nilai karakter bangsa

Berdasarkan pengamatan penulis banyak hal yang ditemui selama pembelajaran tatap muka secara terbatas. Saat proses pembelajaran terbatas di sekolah, pengajar kesulitan mengenali siswa secara individual, selama ini hanya mengenal siswa yang aktif saja saat zoom atau meet dalam proses belajar normal di kelas apalagi saat tatap muka dengan siswa diwajibkan tetap memakai masker. Masih banyak siswa yang berpakaian tidak rapi, berambut panjang atau gondrong dan diberi warna, kuku panjang dan remaja putri yang memakai pewarna pipi dan bibir, dari sapaan dan kata kata yang terlontar dari siswa tersebut terasa tidak sopan dan kasar, yang selayaknya tidak ditemui pada saat pembelajaran selama ini Mereka bisa jadi akan kehilangan pendidikan karakter yang nilainya sangat berharga sebagai bekal menjalani kehidupan. Misalnya sholat dan berdoa bersama, suka bekerjasama, menghargai teman saat saling berinteraksi secara langsung, sopan, berkepribadian terbuka dan ramah

Akses informasi tanpa batas memudahkan setiap orang untuk belajar apapun. Namun pembelajaran berbeda 
dengan pendidikan, apalagi pendidikan karakter. Bangsa ini butuh generasi muda yang karakter positifnya terbentuk dan itu hanya bisa diraih dengan pendidikan karakter secara menyeluruh yang mengedepankan keteladanan para pengajar dan para pengambil kebijakan, yang harus disaksikan dan ditiru langsung oleh para siswa.

Sudah saatnya pemerintah dan segenap elemen pendidikan di Indonesia memikirkan bagaimana cara mengganti pendidikan karakter yang selama masa pandemi ini terpaksa harus terabaikan dan tidak tersentuh karena keterbatasan waktu dan kewajiban transfer ilmu oleh guru. Jangan sampai hilangnya nilai-nilai pendidikan karakter juga menjadi bagian dari amanat dalam visi dan misi sekolah. Sehingga nantinya kita tak lagi merasa aneh melihat generasi muda yang kehilangan karakter-karakter positif karena pendidikan kita akhirnya didominasi pembelajaran daring yang hanya mengedepankan transfer pengetahuan tanpa penanaman nilai-nilai akhlak yang mulia. Itulah yang sangat diperlukan bangsa ini untuk memperbaiki keadaannya sendiri yang sedang dilanda banyak masalah seperti sekarang ini.bahwa ilmu pengetahuan yang dikuasai tanpa ahlak dan adab sebagai penuntunnya akan membawa kesombongan dan ilmu tanpa agama akan membawa pada kehancuran dan murka Allah di dunia dan akhirat.

Harapan kita semoga dalam pembelajaran tatap muka secara terbatas yang sudah sangat ditunggu-tunggu siswa dan pendidik, dapat segera memutus rantai ketimpangan dan kemerosotan kualitas pendidikan di Indonesia, yang sangat terdampak akibat pandemi yang berkelanjutan. Selain itu, hal ini juga untuk menghindari ancaman 
banyaknya anak putus sekolah karena ketidaktersediaan fasilitas pembelajaran daring.

\section{Daftar Pustaka}

Marzuki. (2012). Pengintegrasian Pendidikan Karakter dalam Pembelajaran di Sekolah. Jurnal pendidikan Karakter , 34.

Dewangga, T. A. (2012, Agustus 03). Pendidikan Karakter untuk Membangun Manusia Indonesia yang Unggul. Dipetik November 15, 2012, dari http://www.setkab.go.id.

Kemdiknas. (2010). Desain Induk pendidikan Karakter. Jakarta: Kementerian Pendidikan Nasional.

Asmuni. 285 Problematika Pembelajaran Daring, Jurnal Paedagogy Oktober 2020: Vol. 7. No. 4 Copyright (C) JP 2020, 


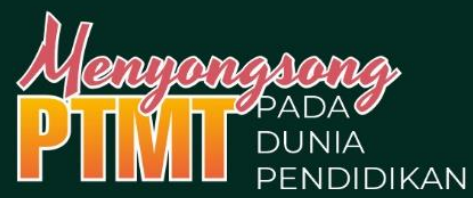

Uulisan dalam buku ini adalah buah pikiran para penulis dari berbagai profesi baik itu guru, dosen dan bahkan ada juga yang berasal dari Instansi pemerintah yang menduduki jabatan struktural dengan latar belakang pendidikan yang berjenjang dan berbeda-beda satu sama lainnya baik yang profesinya berkaitan dengan dunia pendidikan maupun lainnya, semua menjadi satu dalam tulisan yang dapat memperkaya pemikiran para pembaca buku Bunga Rampai ini.

Kerinduan yang sangat tinggi akan proses belajar secara normal menjadi pemikiran yang mendasar dari para penulis Buku Bunga Rampai ini untuk berbagi pemikiran, sehingga muncul berbagai topik yang berbeda-beda dalam tulisan ini sehingga sangat layak untuk dibaca dan dapat memperkaya pemikiran para pembaca seperti apa kondisi riil dan penerimaan para murid, orangtua dan masyarakat di tengah kondisi pandemi yang masih belum tuntas secara seutuhnya. Kondisi ini harus disikapi semua pihak dengan meningkatkan pengetahuannya, keterampilannya dan perilaku seperti apa yang harus diwujudkan di pasca pandemi ini.

Proses belajar di dunia pendidikan pada pasca pandemi covid-19 memang akan berjalan unik dan menarik untuk dikaji secara empiris, teoretis dan berbagai pengalaman yang dialami guru dan murid selama proses belajar daring (online) dapat dijadikan inspirasi untuk diurai dalam wujud tulisan-tulisan ringan yang layak untuk di ketahui banyak orang dan layak dimuat dalam Buku Bunga Rampai ini. Para penulis buku ini akan berbeda sudut pandangnya melihat penyelenggaraan pendidikan di pasca pandemi, tetapi pada prinsipnya sama yakni bagaimana proses belajar di sekolah dan di rumah siswa dapat mengikutinya dan berbagai materi yang tertinggal selama proses belajar daring selama kurun waktu 2 tahun ini dijadikan dasar berpikir yang kuat untuk mau lebih meningkatkan lagi keinginan belajarnya baik di sekolah maupun di rumah.

\section{Akademia Pustaka}

Perum. BMW Madani Kavling 16, Tulungagung

(1) https://akademiapustaka.com/

@redaksi.akademia.pustaka@gmail.com

@ @redaksi.akademia.pustaka

(0)@akademiapustaka

081216178398

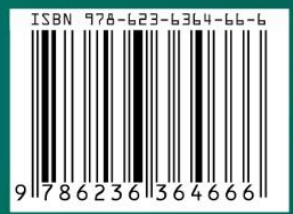

